\title{
33. HIGH-RESOLUTION FORAMINIFER, PALYNOLOGIC, AND STABLE ISOTOPIC RECORDS OF UPPER PLEISTOCENE SEDIMENTS FROM THE LABRADOR SEA: PALEOCLIMATIC AND PALEOCEANOGRAPHIC TRENDS ${ }^{1}$
}

\author{
A. E. Aksu, ${ }^{2}$ A. de Vernal, ${ }^{3}$ and P. J. Mudie ${ }^{4}$
}

\begin{abstract}
Faunal and stable isotopic data in Sites 646 and 647 provide a $\sim 0.9$-Ma paleoclimatic and paleoceanographic record for the Labrador Sea, that is supported by a floral record for the past $\sim 0.3 \mathrm{Ma}$. At both sites, most glacial stages generally are dominated by polar fauna and flora with low species diversity. Although minor occurrences of subpolar species also were observed in lowermost parts of several glacial stages in Site 646, the faunal classification of Ruddiman and McIntyre (1976) suggested the presence of polar ecological water masses in the area during most of the glacial periods. In several glacial stages at Site 647 , both the faunal and floral data indicate that early periods were marked by subpolar and transitional ecological water masses. The interglacials are characterized by a polar fauna at Site 646 and by polar and transitional faunas and floras at Site 647. However, several interglacial stages in Site 646 include a subpolar flora, in contrast to a planktonic foraminifer fauna similar to that found in the glacial stages. The occurrence of subpolar water masses in several glacial isotopic stages indicates significant northward advection of warmer waters into the Labrador Sea during the early glacial periods, which provided a corridor of oceanic warmth extending from mid- to high latitudes and contributed an additional source of moisture for continental ice-sheet growth. Similar conditions also were documented in the northwest Labrador Sea, Grand Banks, and the North Atlantic.
\end{abstract}

\section{INTRODUCTION}

The Labrador Sea forms the western branch of the Atlantic Ocean and constitutes a major conduit between the Arctic and Atlantic oceans (Fig. 1). During Ocean Drilling Program (ODP) Leg 105, four holes were drilled at two sites in the Labrador Sea (Fig. 1; Table 1). Site 646 (Holes 646A and 646B) was drilled on the north flank of the Eirik Ridge, which is the most northerly of several large sediment drifts in the northwest Atlantic. Site 646 is situated beneath the present-day subarctic West Greenland Current. Site 647 (Holes 647A and 647B) is located about $100 \mathrm{~km}$ south of the Gloria Drift in the southern Labrador Sea. The site is situated beneath the northernmost part of today's North Atlantic Drift (Fig. 1).

Studies conducted with shorter piston cores from the Labrador Sea and the North Atlantic and raised marine deposits on the Canadian Arctic Archipelago and Greenland provide paleoclimatic and paleoceanographic data that have led to conflicting models to explain the timing, driving mechanism, and magnitude of glacial/interglacial climatic oscillations (Mudie and Aksu, 1984; Aksu and Mudie, 1985). The "North Atlantic Model" is based primarily on the synthesis of foraminiferal oxygen isotopic data and faunal and floral indicators of sea-surface temperature and salinity (Ruddiman and McIntyre, 1981a, 1981b). The model suggests a long-term buildup of continental ice sheets over $\sim 100,000 \mathrm{yr}$, with an initial rapid phase that is followed by a longer, gradual phase and southward advance of the polar front and that culminates in rapid deglaciation in less than $10,000 \mathrm{yr}$. The final disintegration of the marine-based ice sheets apparently was caused by initial warming and melting of

\footnotetext{
${ }^{1}$ Srivastava, S. P., Arthur, M., Clement, B., et al., 1989. Proc. ODP, Sci. Results, 105: College Station, TX (Ocean Drilling Program).

2 Department of Earth Sciences, Centre for Earth Resources Research, Memorial University of Newfoundland, St. John's, Newfoundland A1B 3X5, Canada.

${ }^{3}$ Département des Sciences de la Terre GEOTOP, Université du Québec à Montréal, CP 8888 Succursale "A," Montréal, Québec H3C 3P8, Canada.

${ }^{4}$ Atlantic Geoscience Centre, Geological Survey of Canada, Bedford Institute of Oceanography, P.O. Box 1006, Dartmouth, Nova Scotia B2Y 4A2, Canada.
}

ice. This was followed by a rise in sea level, which triggered rapid calving and deflation of the ice sheets (Denton and Hughes, 1983). Warming and melting cycles of lower amplitude are thought to be induced by increased solar insolation related to the 23,000-yr precessional cycle (Ruddiman and McIntyre, 1981a, 1981b).

The "Arctic Model" is based largely on radiometric dating of raised marine deposits from the Canadian Arctic Archipelago and Greenland (Andrews et al., 1983). The terrestrial data suggest rapid buildup of ice sheets in less than $15,000 \mathrm{yr}$, near the end of interglacial/interstadial intervals characterized by the northward advection of subarctic water masses into the northern Labrador Sea and Baffin Bay and by equally rapid glacial terminations. Piston core data from deep-sea areas of the Labrador Sea and southern Baffin Bay support the "Arctic Model" in part, but the oxygen isotopic and dinoflagellate data confirm a global signal (Mudie and Aksu, 1984; Aksu and Mudie, 1985). Comparison of the planktonic foraminifer and dinoflagellate data revealed that the subarctic dinoflagellate peaks did not match precisely the occurrence of subarctic foraminifers, which suggests that carbonate dissolution may have affected the calcareous fauna (Aksu and Mudie, 1985).

The primary scientific objectives for drilling the Neogene section in the Labrador Sea were (1) to determine the timing, magnitude, and periodicity of high-amplitude, late Cenozoic climatic fluctuations in high latitudes, which responded to Laurentide, Innuitian, and Greenland ice-mass fluctuations; (2) to determine the late Cenozoic paleoclimatic and paleoceanographic variations along the north-south transect in the Labrador Sea; and (3) to test the validity of conflicting models of glaciation.

\section{MATERIAL AND TECHNIQUES}

To determine a high-resolution stratigraphy for the Pleistocene to Holocene sediments recovered in the Labrador Sea sites, approximately 930 foraminifer and stable-isotope samples $\left(\sim 10 \mathrm{~cm}^{3}\right.$ volume) were retrieved at depth intervals of $20 \mathrm{~cm}$ in all core sections in the upper 90 and $55 \mathrm{~m}$ of Sites 646 (690 samples) and 647 (240 samples), respectively. Because of incomplete sediment recovery in Site 646, cores from both Sites 646A (105-646A-1H through 105-646A-8H) and 646B (105-646B$1 \mathrm{H}$ through $105-646 \mathrm{~B}-9 \mathrm{H})$ were sampled for detailed analyses. Core recovery was excellent in Site 647; and only Cores 105-647B-1H through 


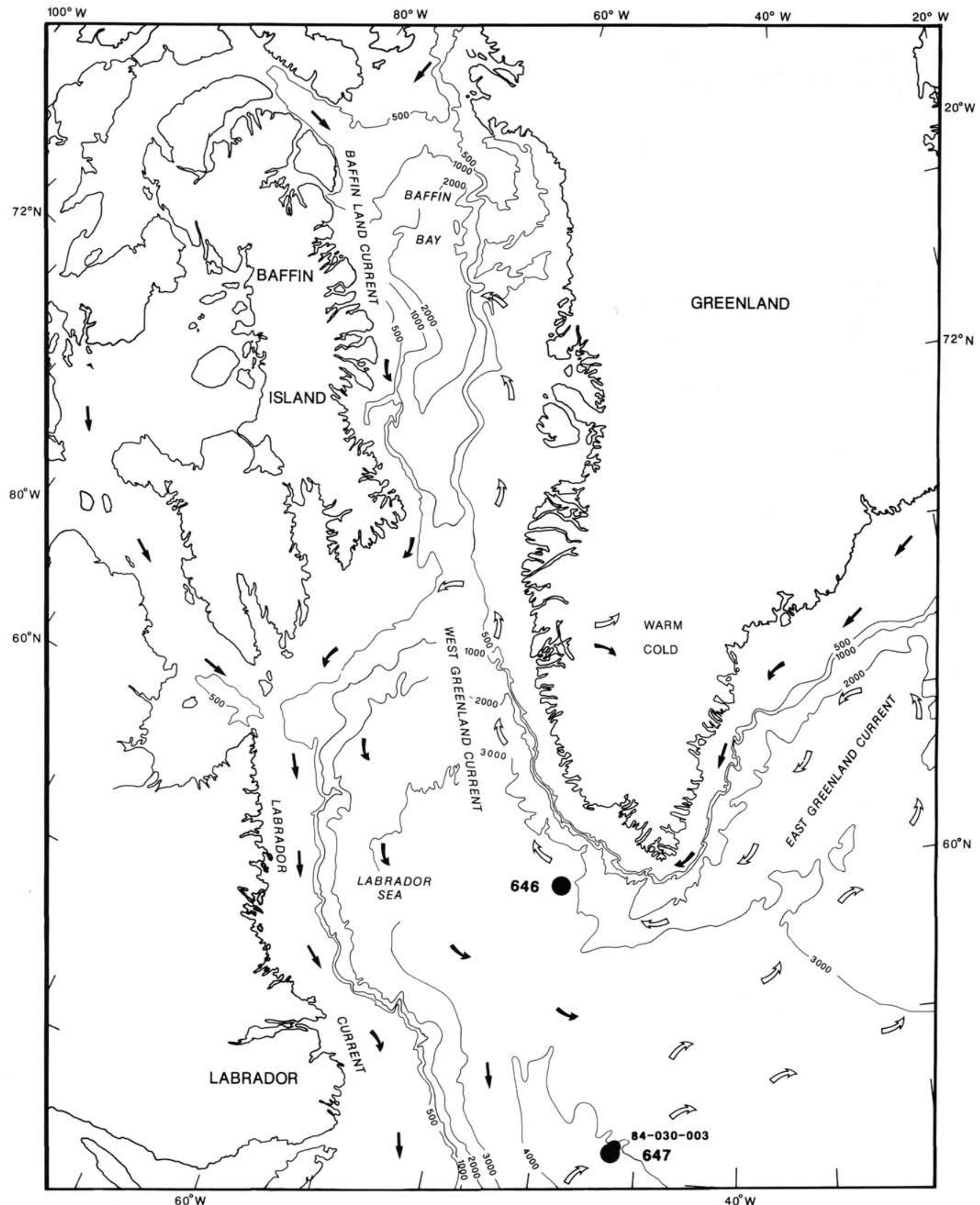

Figure 1. Bathymetric map of the Labrador Sea showing the locations of Sites 646 and 647 and the position of today's surface water circulation. 
Table 1. Location and water depth of Sites 646 and 647, Leg 105.

\begin{tabular}{rccc}
\hline Hole & $\begin{array}{c}\text { Latitude } \\
(\mathrm{N})\end{array}$ & $\begin{array}{c}\text { Longitude } \\
(\mathrm{W})\end{array}$ & $\begin{array}{c}\text { Water depth } \\
(\mathrm{m})\end{array}$ \\
\hline $105-646 \mathrm{~A}$ & $58^{\circ} 12.559^{\prime}$ & $48^{\circ} 22.147^{\prime}$ & 3461.7 \\
$646 \mathrm{~B}$ & $58^{\circ} 12.559^{\prime}$ & $48^{\circ} 22.147^{\prime}$ & 3458.7 \\
$647 \mathrm{~A}$ & $53^{\circ} 19.876^{\prime}$ & $45^{\circ} 15.717^{\prime}$ & 3869.0 \\
$647 \mathrm{~B}$ & $53^{\circ} 19.876^{\prime}$ & $45^{\circ} 15.717^{\prime}$ & 3870.7 \\
\hline
\end{tabular}

105-647B-6H were sampled for foraminifer and stable-isotope analyses. Sedimentation rates that were calculated based on the paleomagnetic data (Clement et al., this volume) and the oxygen-isotope stratigraphy (discussed below) suggested that the $20-\mathrm{cm}$ sampling interval provides a temporal resolution of $\sim 2200$ and $4400 \mathrm{yr}$ for Holes 646 (composite) and $647 \mathrm{~B}$, respectively.

For foraminifer study, samples were disaggregated in $1 \%$ Calgon solution and wet sieved through a $63-\mu \mathrm{m}$ screen. The coarse fractions were dried in an oven, then weighed; the fine fractions were saved for further studies. All samples were dry sieved again through a $149-\mu \mathrm{m}$ screen. Planktonic foraminifers were separated at $>149-\mu \mathrm{m}$ fraction, identified, and counted following the methods described by Aksu (1985). Total foraminifer abundances were converted to "specimens per gram dry weight sediment," whereas individual species abundances were displayed as percentages of the total planktonic foraminifers. Oxygen and carbon isotopic variations in Neogloboquadrina pachyderma (sinistral) were determined in the upper 90 and $55 \mathrm{~m}$ of Sites 646 and 647 , respectively. About 250 to 500 specimens of $N$. pachyderma were handpicked from each sample for the stable-isotope analyses (a few analyses were performed on $<100$ specimens). The foraminifer shells were cleaned in distilled water and dried in an oven at $90^{\circ} \mathrm{C}$. Foraminifer shells were transferred into double-arm reaction vessels and placed in water at $50^{\circ} \mathrm{C}$ for about $2 \mathrm{hr}$. They were acidified with $100 \%$ phosphoric acid. The reaction vessels were transferred into a vacuum line where the water in the evolved $\mathrm{CO}_{2}$ was trapped with a dry-ice and methanol mixture $\left(\sim-85^{\circ} \mathrm{C}\right)$. The purified $\mathrm{CO}_{2}$ was collected in 6-mm pyrex tubes, sealed, and stored for stable-isotope analyses. The isotopic ratios of ${ }^{18} \mathrm{O} /{ }^{16} \mathrm{O}$ and ${ }^{13} \mathrm{C} /{ }^{12} \mathrm{C}$ were determined using a VG Micromass $903 \mathrm{E}$ triple collector mass spectrometer at the Memorial University of Newfoundland. Several duplicate analyses performed on the laboratory standard MUN1 and selected samples showed that the reproducibility varied from \pm 0.04 to \pm 0.08 . The isotopic ratios are expressed as per mil $(\% 0)$ difference between the ${ }^{18} \mathrm{O} /{ }^{16} \mathrm{O}$ and ${ }^{13} \mathrm{C} /{ }^{12} \mathrm{C}$ in the samples and the laboratory standard. Here, isotopic data are reported relative to Chicago PDB-1.

Palynological analyses were performed only in the upper $\sim 27 \mathrm{~m}$ of Holes 646A and 646B. A known volume of sample (usually 5 to $10 \mathrm{~cm}^{3}$ ) was dispersed in distilled water with $1 \mathrm{~mL}$ of calibrated suspension of Eucalyptus globulus pollen grains. Each sample was sieved through 10and $125-\mu \mathrm{m}$ screens to eliminate the fine and coarse particles. The carbonates were destroyed by $10 \%$ cold $\mathrm{HCl}$; the silicates were removed by repeated treatment of $48 \%$ hot $\mathrm{HF}$ for 1 to $12 \mathrm{hr}$. Fluorosilicates formed during the $\mathrm{HF}$ treatment were removed by $10 \%$ hot $\mathrm{HCl}$ treatment $(15$ min). Samples were rinsed with distilled water, again sieved with a 10$\mu \mathrm{m}$ screen, and mounted on slides in glycerine jelly. Palynomorphs were counted systematically for each sample. Palynomorph concentrations were determined following the marker-grain technique (see Matthews, 1969). The spike of Eucalyptus globulus marker grains was calibrated and counted several times on a hemacytometer. The marker-grain method yields accurate results to approximately $10 \%-12 \%$ for a confidence interval of $\alpha=0.95$ (de Vernal et al., 1987). The Index of Genera and Species of Lentin and Williams (1985) was used as a reference for the dinoflagellate cyst nomenclature.

Planktonic foraminifer and stable isotopic analyses on planktonic foraminifers were conducted by A. Aksu at the Memorial University of Newfoundland. Palynological analyses were performed by A. de Vernal at the Université du Québec à Montréal.

\section{RESULTS}

\section{Site 646}

Two APC holes were cored at Site 646. Core recovery for the first nine cores in Holes 646A and 646B $(\sim 82 \mathrm{~m})$ varied from
$73.5 \%$ to $99.8 \%$ and $0 \%$ to $153.7 \%$, respectively (Srivastava, Arthur, et al., 1987). From these results we could see that none of these holes alone were suitable for detailed paleoenvironmental studies. However, visual core descriptions and examination of whole-core photographs indicated the presence of several calcareous silty clay beds, which allowed us to establish a detailed lithostratigraphic correlation between Holes 646A and 646B (Srivastava, Arthur, et al., 1987). This correlation provides a virtually complete upper Pleistocene to Holocene section for Site 646 (Fig. 2).

Here, the planktonic foraminifer and stable isotopic data from Holes 646A and 646B are presented separately (Figs. 3 and 4). A composite section was constructed using shipboard lithostratigraphic correlations between Holes 646A and 646B (Srivastava, Arthur, et al., 1987) and the foraminifer abundance peaks and stable isotopic values (Fig. 5). The data are tabulated in Appendix A.

\section{Oxygen Isotopes and Chronostratigraphy}

Planktonic foraminifers were picked for stable isotopic studies from the same suite of samples used to determine the foraminifer assemblages. The oxygen isotopic data in Holes 646A and $646 \mathrm{~B}$ fluctuates from $4.5 \%$ to $1.6 \%$ (Figs. 3 and 4 ). Because of poor recovery in both holes, isotopic stages could not be assigned based solely on these data. The composite isotopic data from Site 646 show alternating cycles of heavy and light oxygen isotopic values (Fig. 5). Based on character and amplitude, these heavy and light isotopic intervals are correlated with oxygen isotopic stages 1 through 24 (Fig. 5). Below stage 24 the sampling interval of $150 \mathrm{~cm}$ and sparse occurrence of planktonic foraminifers do not allow further isotopic stage definitions. The amplitudes of the isotopic data from Site 646 are comparable to those obtained from the North Atlantic (i.e., DSDP Leg 94; Ruddiman et al., 1987).

The first appearance datum (FAD) of Emiliania huxleyi was found between Samples 105-646A-2H-6, 102-104 cm, and 105646A-2H-5, 102-104 cm, in Hole 646A (Knuttel et al., this volume). This datum occurs within isotopic stage 7 ( 0.244 to 0.190 Ma) in Site 646 (Fig. 5), but was reported as occurring in isotopic stage $8(\sim 0.275 \mathrm{Ma})$ elsewhere (Berggren et al., 1985). We are not sure why the FAD of this taxon is apparently younger at Site 646. In Hole 646A the last appearance datum (LAD) of Pseudoemiliania lacunosa occurs between Samples 105-646A$4 \mathrm{H}-6,96-98 \mathrm{~cm}$, and $105-646 \mathrm{~A}-4 \mathrm{H}-5,96-98 \mathrm{~cm}$ (Knuttel et al., this volume). This datum occurs near the middle of isotopic stage 12 (Fig. 5), which is consistent with the age reported for the LAD of this taxon at $\sim 0.474 \mathrm{Ma}$ (Berggren et al., 1985). Both the oldest studied samples from Holes 646A and 646B lie above the LAD of Calcidiscus macintyrei (Knuttel et al., this volume).

The Brunhes-Matuyama magnetic chron boundary occurs near the upper part of isotopic stage 19 (Fig. 5). Elsewhere, this boundary was reported to occur in isotopic stages 19 through 20 (Shackleton and Opdyke, 1976). The top of the Jaramillo subchron was found to occur within isotopic stage 24 . In general, the magnetostratigraphic and biostratigraphic data discussed above collectively support the chronology suggested by the oxygen isotopic data.

\section{Planktonic Foraminifers}

The downcore plots of total planktonic foraminifer abundances show large fluctuations ranging from $<10$ to $>100,000$ specimens per gram sediment (Figs. 3 through 5). These fluctuations may be the result of (1) cyclic changes in the preservation of calcium carbonate debris on the seafloor, (2) changes in the sedimentation rate associated with the climatic cycles, or (3) changes in the oceanographic circulation patterns accompanied by changes in biological productivity. To use the faunal data for 


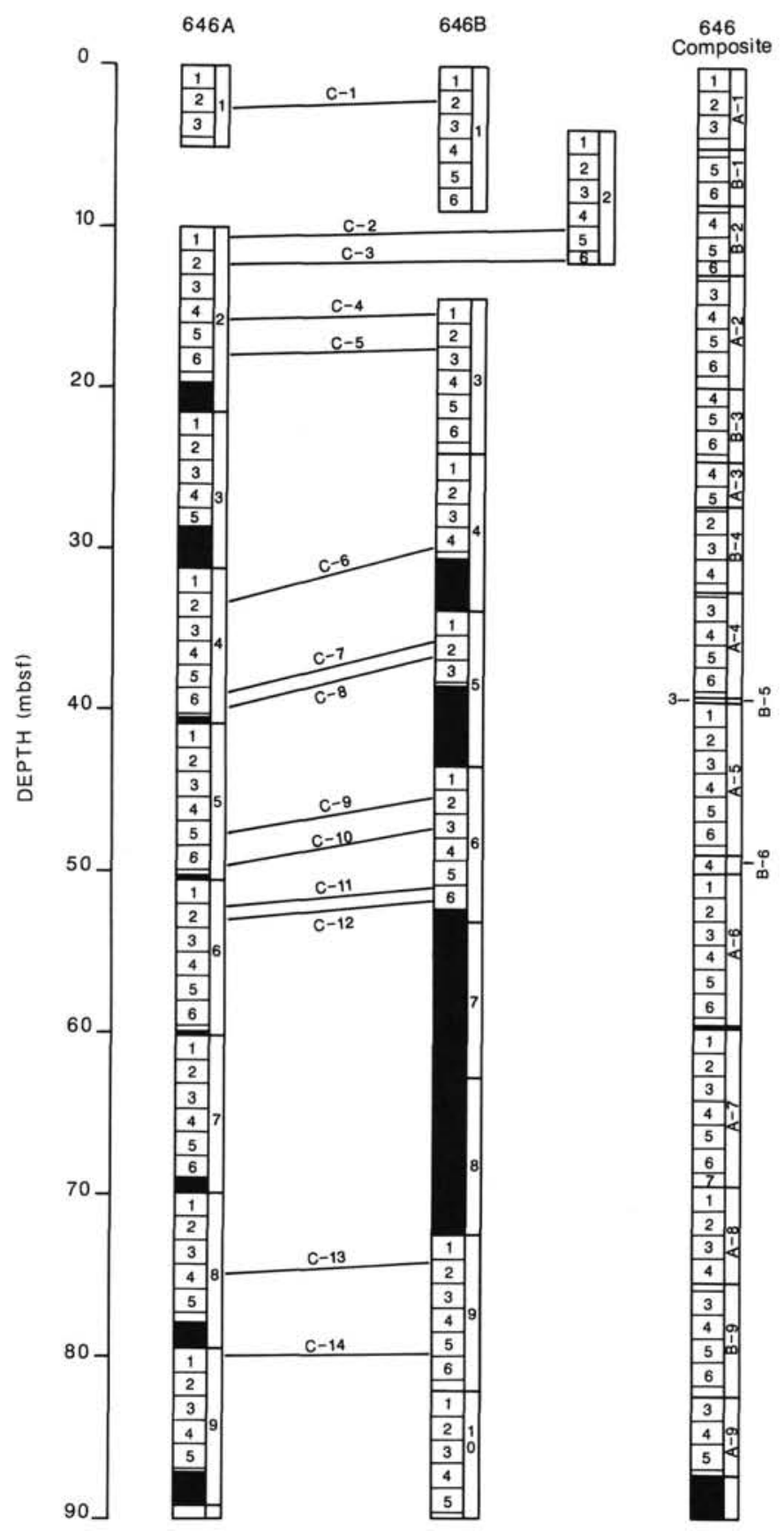

Figure 2. Lithostratigraphic correlation (C-1 to $\mathrm{C}-14)$ between Holes 646A and 646B (Srivastava, Arthur, et al., 1987), which allowed the construction of the composite section. Unrecovered sediments indicated by black areas.

delineating the paleoclimatic and paleoceanographic history of the Labrador Sea, one must determine the effects of these variables on these data. In general, dissolution preferentially removes planktonic foraminifers, which leads to higher benthic to planktonic ratios (B/P) (Thunell, 1976; Berger, 1979). In areas of extensive dissolution, sediments are often barren of planktonic foraminifers, and benthic foraminifers have a chalky appearance and irregular and enlarged pores and sutures (Aksu, 1983). No sample examined in Holes $646 \mathrm{~A}$ or $646 \mathrm{~B}$ was barren of planktonic foraminifers and, in all samples examined, the $\mathrm{B} / \mathrm{P}$ ratios were $<<1$, which suggests that extensive calcium carbonate dissolution did not take place in the Labrador Sea during the last $\sim 1 \mathrm{Ma}$.
Increased fragmentation of foraminifer tests is another indicator of milder dissolution (Berger, 1970; Thunnell, 1976). Downcore plots of foraminifer test fragmentation in Holes 646A and 646B (Figs. 3 through 5) show broad cyclicity in about the upper $30 \mathrm{~m}$ and ranges from $<10 \%$ to $60 \%$. Except for a few shorter intervals, the test fragmentation between $\sim 30$ and $70 \mathrm{~m}$ remains relatively low $(10 \%-30 \%)$ and increases slightly to $20 \%$ $40 \%$ below $70 \mathrm{~m}$. Comparison of the downcore plot of total foraminifers with that of foraminifer test fragmentation reveals that except for a few isolated intervals where increased test fragmentation correlates with lower total planktonic foraminifers, there is no one-to-one correlation between these two variables. Together with the low $\mathrm{B} / \mathrm{P}$ ratios, these data collectively suggest that the fluctuations in the total planktonic foraminifer data cannot be ascribed to dissolution. Comparison of the downcore foraminifer test fragmentation with the isotopic and faunal data shows that low test fragmentation is often associated with interglacial stages that are characterized by lower total foraminifer abundances and high subarctic and transitional planktonic assemblages. In contrast, test fragmentation dramatically increases in glacial stages, which correlates with the decline or disappearance of subarctic and transitional fauna. Dissolution-susceptible planktonic foraminifers, such as Globigerina quinqueloba, G. bulloides, Globigerinitida uvula, and G. glutinata occur predominantly in intervals of reduced test fragmentation. Their general absence in intervals of higher test fragmentation suggests that the faunal record at Site 646 experienced preferential dissolution, the extent of which cannot presently be quantified.

The deposition rates for individual glacial and interglacial stages were calculated using oxygen-isotope stratigraphy and the chronology of Martinson et al. (1987) for stages 1 through 8 and Shackleton and Opdyke (1976) for stages 9 through 18. The deposition rate varied from 11.5 to $5.0 \mathrm{~cm}$ per $1000 \mathrm{yr}(\mathrm{cm} / \mathrm{k} . \mathrm{y}$.) in interglacial stages 1 and 9 , and 15.0 and $7.3 \mathrm{~cm} / \mathrm{k} . \mathrm{y}$. in glacial stages 10 and 4 , with a glacial and interglacial average of 10.5 and $9.7 \mathrm{~cm} / \mathrm{k} . \mathrm{y}$., respectively. Magnetostratigraphic and biostratigraphic data generally support the overall sedimentation rate of $10.1 \mathrm{~cm} / \mathrm{k}$.y. suggested by the oxygen isotopic stratigraphy. Figure 5 shows the cyclic changes in the percentage of sediment that is coarser than $63 \mu \mathrm{m}$ in Site 646. This fraction includes the biogenic materials that are mostly foraminifers as well as the terrigeneous sand- and gravel-sized debris. In general, the interglacial stages are characterized by low sand content and glacial stages by high sand influx. Comparison of downcore plots of the $>63-\mu \mathrm{m}$ data with those of total planktonic foraminifer abundances shows that except for a few isolated zones, there is little correlation among these variables. This lack of correlation suggests that the $>63-\mu \mathrm{m}$ fraction is controlled largely by the terrigeneous influx and probably relates to episodic spillovers from the North Atlantic Mid-Ocean Canyon and/or periods of increased ice rafting during glacial stages. Thus, temporal variation in sedimentation rates does not appear to be a major factor controlling the downcore fluctuations in total foraminifer abundances in Holes 646A and 646B. An increase in deposition rate should cause a reduction in the concentration of planktonic foraminifers; however, the data presented in Figures 3 through 5 illustrate that changes in deposition rate had little effect on total faunal concentrations. Thus, we concluded that the abundance variations in the total planktonic foraminifers represent first-order biogenic productivity in the eastern Labrador Sea.

Comparison of the faunal and the oxygen isotopic data reveals that several interglacial stages have few foraminifers (such as stages $1,7,9,11,15,17$, and lower stage 5). In contrast, isotopic stages 13,19 , and 21 and the upper part of stage 5 are rich in foraminifers. In general, glacial stages are dominated by $N$. pachyderma (sinistral) with minor occurrences of $N$. pachyderma (dextral). Minor occurrences of $G$. bulloides and G. quinque- 
loba also were observed in lowermost portions of isotopic stages 2,6 , and 12 and sporadic occurrences in stages $8,14,18,20$, and 22 , with scattered occurrences of $G$. uvula, G. glutinata, and Globorotalia inflata (only in stage 14). Several interglacial stages (i.e., 1 through 13, and 17) are dominated by $N$. pachyderma (dextral), G. bulloides, and G. quinqueloba, with smaller percentages of $N$. pachyderma (sinistral), G. uvula, and G. glutinata. Globorotalia inflata occurs as a significant percentage of the fauna only in interglacial stages 5,11 , and 17 , but also sporadically occurs in stage 13 . However, interglacial stages 15,19 , 21 , and 23 include a planktonic foraminifer fauna similar to that found in the glacial stages.

\section{Dinoflagellates}

Dinoflagellate cysts are relatively abundant in Pleistocene sediments of Site 646. However, concentrations show large fluctuations ranging from about 100 to 25,000 cysts $/ \mathrm{cm}^{3}$ (Fig. 6). Assuming uniform sedimentation rates of approximately $10 \mathrm{~cm} /$ k.y., the dinocyst concentrations should reflect strong changes in the influxes and range from $<1$ to 225 cysts $/ \mathrm{cm}^{2} / \mathrm{yr}$. Comparison of dinoflagellate data with the oxygen isotopic record shows that dinocyst influxes follow a cyclical trend, with high dinocyst concentrations corresponding to interglacial isotopic stages 1,5 , and 7 , and low dinocyst concentrations corresponding to glacial isotopic stages 2,6 , and to a lesser extent, 8 . These data suggest that the primary productivity was one to two orders of magnitude higher during interglacial episodes. Concentrations of foraminifer linings (from juvenile planktonic or small benthic foraminifers) show similar cyclical trends, which further suggests an overall increase in biogenic productivity during the interglacial periods.

A relatively high dinoflagellate cyst diversity characterizes the Pleistocene thanatocoenose at Site 646 (Fig. 7). Although cool-temperate to subarctic taxa generally dominate the microplankton assemblage, warm-temperate to subtropical and arctic components also occur throughout the sedimentary sequence. The influx of warm-temperate to subtropical taxa Impagidinium strialatum, I. aculeatum, I. patulum, and Lingulodinium machaerophorum (Harland, 1983; Turon, 1984), is almost continuous. Because of very low concentrations, the occurrence of warm dinoflagellate taxa indicates penetration of North Atlantic waters into the Labrador Sea during the late Quaternary. The incursion of North Atlantic waters into the Labrador Sea is also supported by the high-resolution palynological record of Core 84-030-003 (Site 647 survey core; de Vernal and Hillaire-Marcel, 1987).

The episodes of high dinoflagellate productivity corresponding to interglacial stages are marked by assemblages dominated by Operculodinium centrocarpum, Nematosphaeropsis labyrinthea, and Spiniferites ramosus, which constitute a temperatesubarctic association (Fig. 7) similar to that recorded in modern sediments from the Labrador Sea (Mudie and Short, 1985; de Vernal, 1986). In addition to the above species, the noticeable occurrence of temperate taxa such as Bitectadinium tepikiense and S. mirabilis (Harland, 1983; Turon, 1984) characterizes the dinocyst assemblages. These taxa predominantly occur in isotopic stages 5 and 7 , indicating that the surface waters were warmer (?more temperate) than today's waters. The occurrence of Achomosphaera andolousienis in the lowermost part of stage 7 suggests relatively temperate conditions in surface waters.

In addition to the temperate and subarctic components, the late Quaternary dinocyst record of Site 646 is marked by peaks of Brigantedinium simplex, which today is associated with lowsalinity $(<30 \%$ conditions in surface waters (Mudie and Short, 1985). Peaks of $B$. simplex generally correspond to periods of pronounced depletion in the $\delta^{18} \mathrm{O}$ record and occur notably in isotopic stage 8 , in the middle part of stage 7 , in late stage
5 (5a), stage 3 , and at the stage $1 /$ stage 2 transition, which probably reflects brief episodes of dilution in surface waters from meltwater transits through the West Greenland Current.

\section{Pollen and Spores}

In the middle and upper Pleistocene sediments of Site 646, pollen and spore concentrations vary from about 10 to 2000 grains $/ \mathrm{cm}^{2}$, indicating strong changes in influxes in response to variations in the vegetation density of the source area (Fig. 8). On the whole, changes in pollen concentrations correlate with the $\delta^{18} \mathrm{O}$ stratigraphy: the highest concentrations are recorded in deposits that correspond to isotopic stages 1,5 , and 7 , while the lowest concentrations characterize glacial stages 2 and 6; however, isotopic stage 8 is marked by fluctuating pollen concentrations.

The relative abundance of terrestrial palynomorphs in Site 646 is illustrated in Figure 8. Most of the pollen and spore spectra are dominated by Pinus, which is usually over-represented in deep-sea sediments because its bisaccate morphology favors longdistance atmospheric and hydrospheric transportation (Mudie, 1982; Heusser, 1983). Picea is also dominant in the tree pollen assemblages, but the occurrence of other tree pollen grains (e.g., Quercus, Carya, Tsuga) is sporadic. Shrub taxa are relatively well represented, notably by pollen of Alnus crispa, Betula glandulosa, and/or B. unana, (grain diameter $<25 \mu \mathrm{m}$; Richard, 1970; Rousseau, 1974; Usinger, 1975). Herb pollen grains, notably Artemisia, Gramineae, Cyperaceae, and Leguminosae are common in a few intervals but rarely dominate the assemblages. Peridophyte spores (Lycopodium spp., undifferentiated Polypodiaceae, and Osmunda) are abundant in several spectra, and Sphagnum moss spores are common throughout.

Most of the pollen and spore taxa listed above are from anemophilous plants and are easily dispersed over long distances by atmospheric transportation, along with Gramineae and Artemisia herb pollen and Sphagnum spores (Mudie, 1982). Indeed, with the exception of Osmunda, these taxa contribute, in variable proportions, to the modern pollen and spore assemblages of marine sediments off northeastern Canada (Mudie, 1982; Mudie and Short, 1985; Heusser, 1983). These taxa also constitute the main component of long-distance influxes recorded in surficial snow and ice of the Canadian High Arctic (Bourgeois et al., 1985) and the Arctic Ocean (Mudie, 1985). A large part of the pollen and spore assemblages probably corresponds to influxes controlled by atmospheric circulation. The prevalence of Picea pollen indicates an origin in eastern Canada, with subsequent transport in the southeastern/northwestern summer air mass trajectories over the Labrador Sea (Barry and Chorley, 1982). This interpretation is further supported by the Holocene palynostratigraphy at Site 646 and at a nearby core Site 75-37 (de Vernal, 1986), which allow direct correlation with the continental palynostratigraphy of southern Labrador Sea (Lamb, 1980; Engstrom and Hansen, 1985). However, the atmospheric circulation patterns may have changed throughout the late Pleistocene, and one cannot assume that the geographical source area has remained the same. In addition, influx from Greenland through glacial runoff and/or fluvial transportation and subsequent oceanic circulation cannot be ignored.

The assemblages in isotopic stage 8 are characterized by relatively high pollen and spore concentrations, dominated by $\mathrm{Pi}$ cea, Pinus, and Sphagnum. These data suggest the existence of relatively dense spruce forest in the source area. The fluctuating percentages and concentrations reflect cyclical variations of the vegetational cover throughout isotopic stage 8 . In addition, the general increase in herb and shrub taxa in the upper part of stage 8 may indicate a change toward a shrub-tundra vegetation. Persistent occurrence of tree pollen associated with relatively high total pollen and spore concentrations strongly suggests in- 

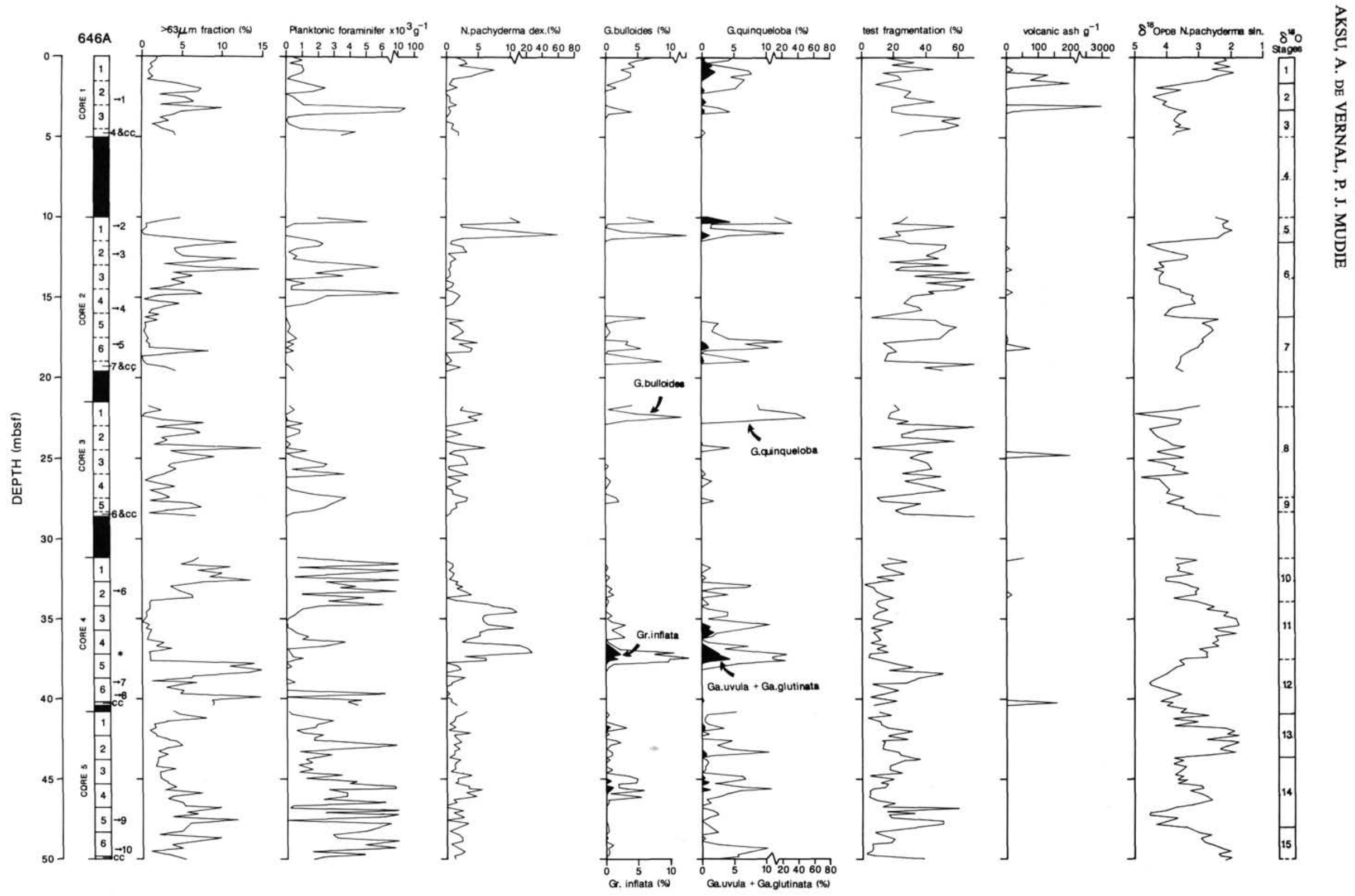

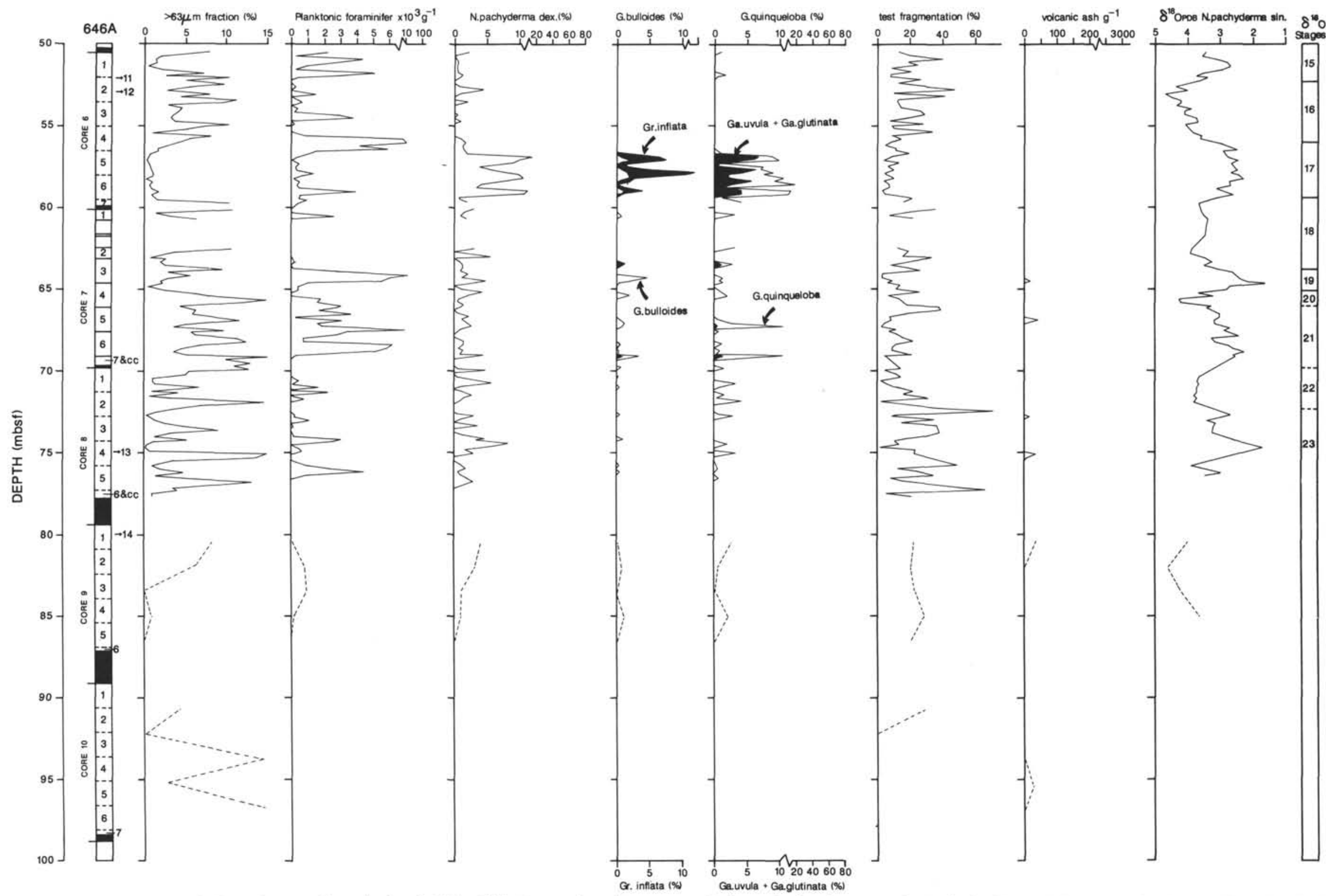

Figure 3. Planktonic foraminifer and oxygen isotopic data in Hole 646A. Oxygen isotopic stages are designated using the composite section in Figure 5. Unrecovered sediments shown as black areas. 

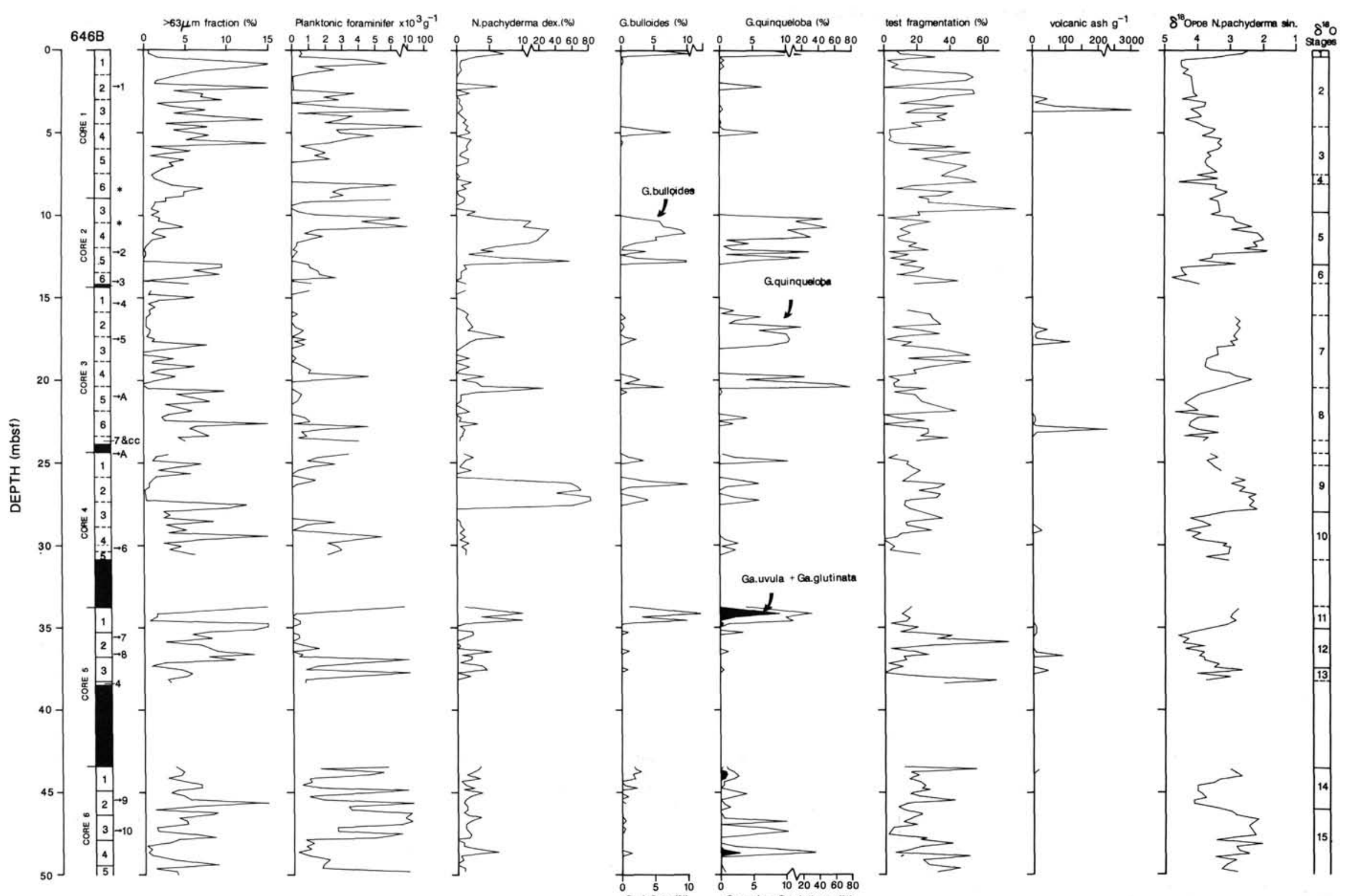

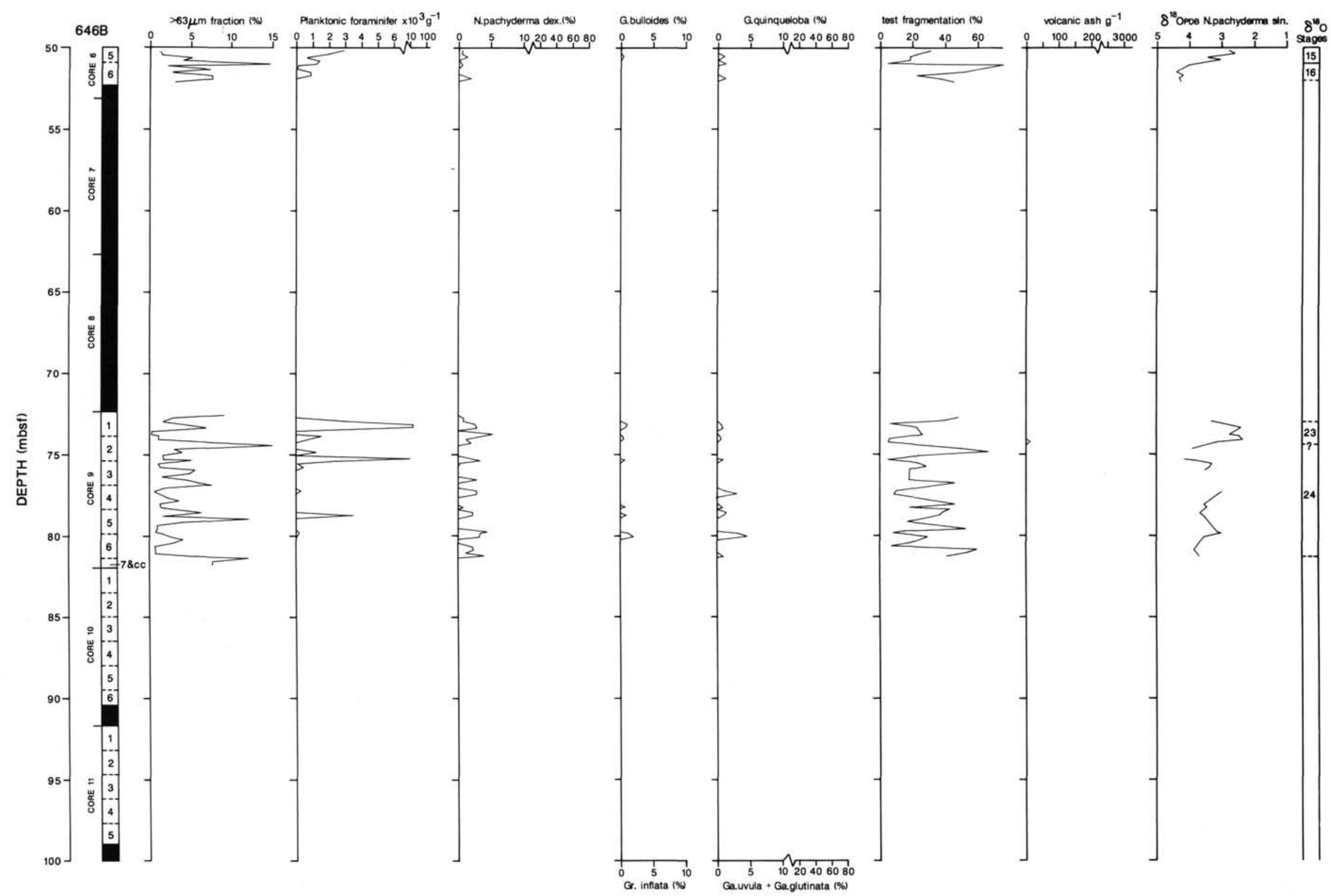

Figure 4. Planktonic foraminifer and oxygen isotopic data in Hole 646B. Oxygen isotopic stages are designated using the composite section in Figure 5. Unrecovered sediments shown as black areas. 

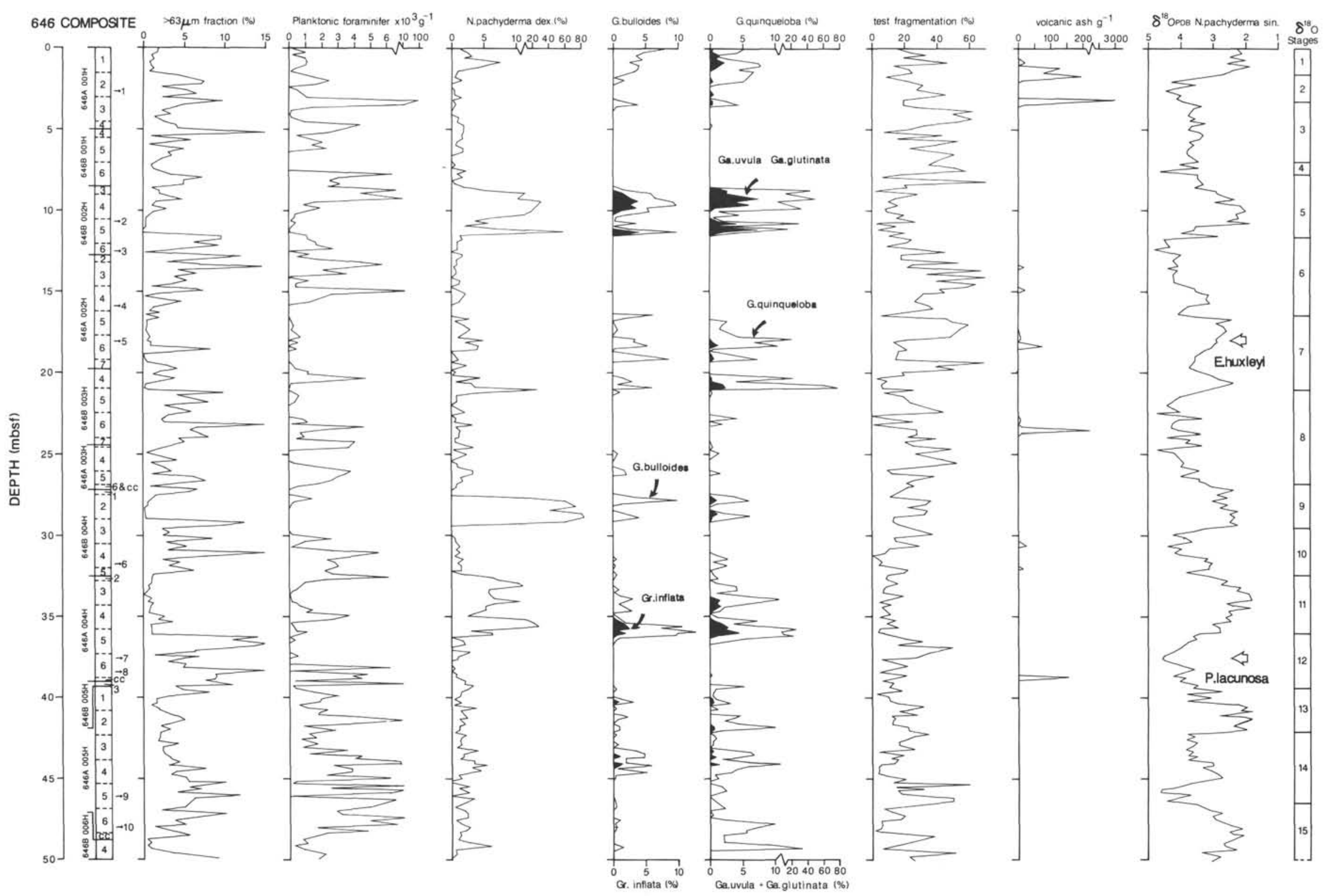

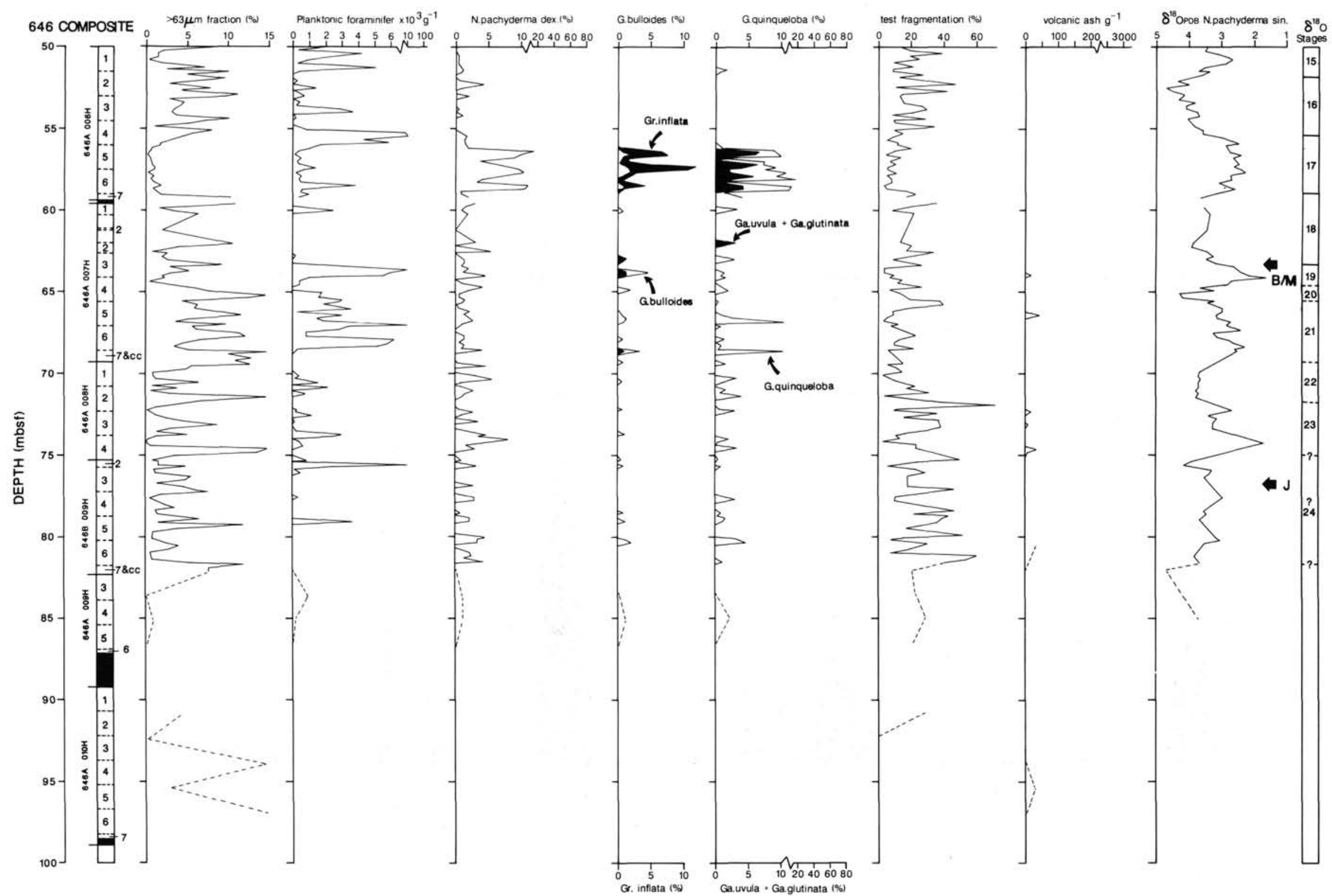

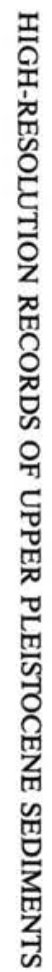

Figure 5. Composite planktonic foraminifer and oxygen isotopic data in Site 646 constructed using the lithostratigraphic correlations between Holes 646A and 646B (Srivastava, Arthur, et al., 1987) and faunal and isotopic data. 

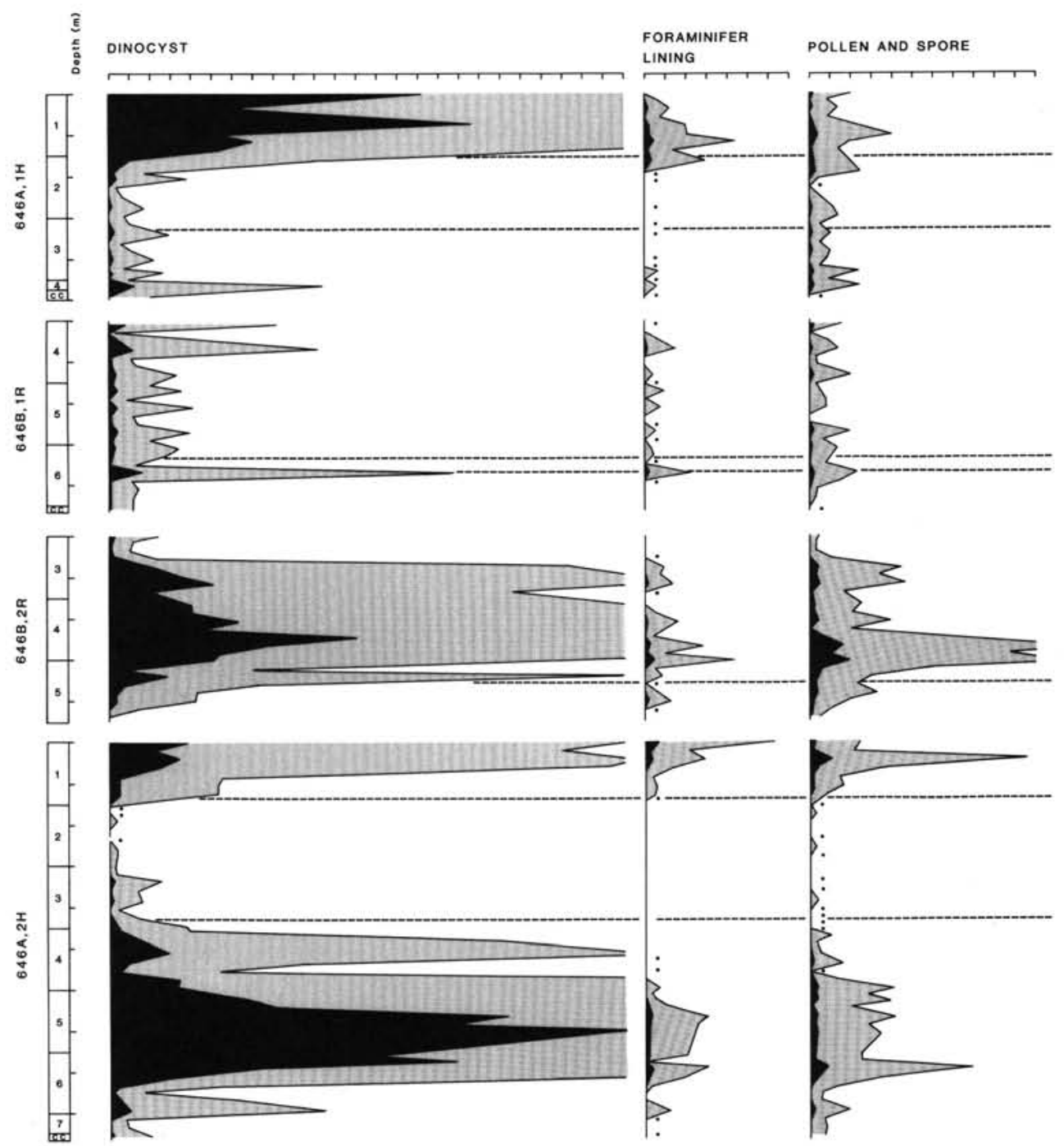

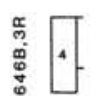
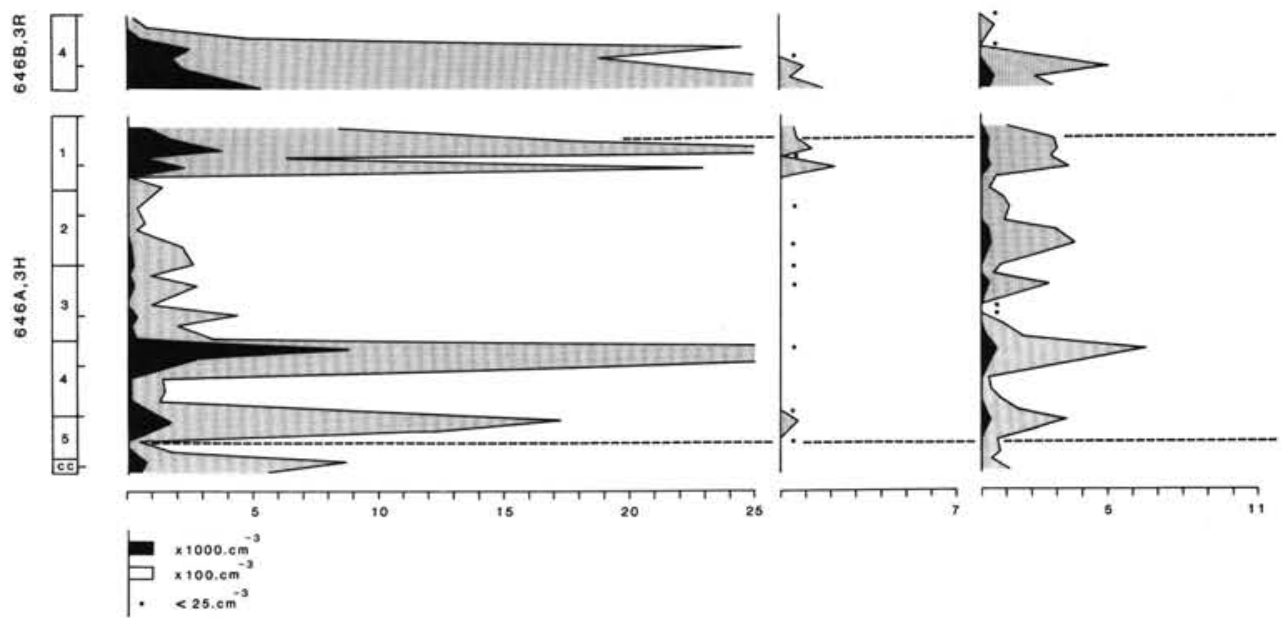

Figure 6. Palynomorph concentrations and $\delta^{18} \mathrm{O}$ curve in a composite upper Pleistocene sedimentary sequence from Site 646 . 

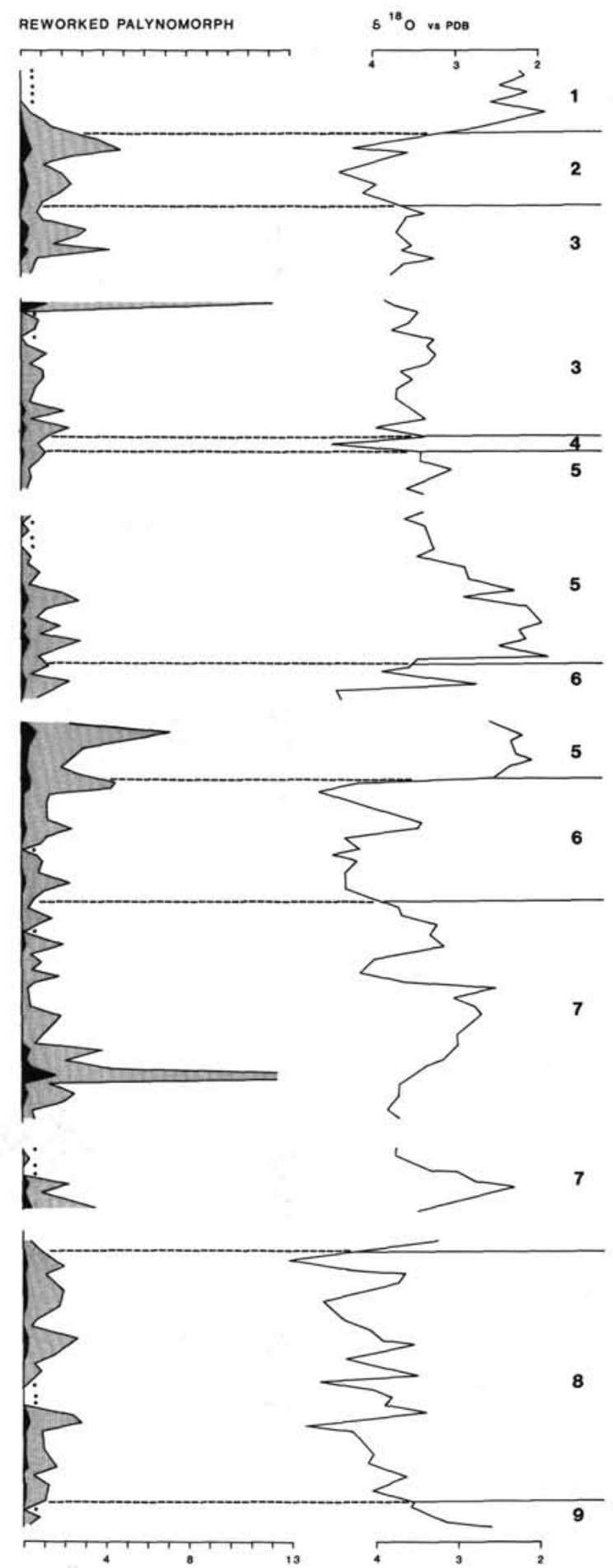

Figure 6 (continued). 


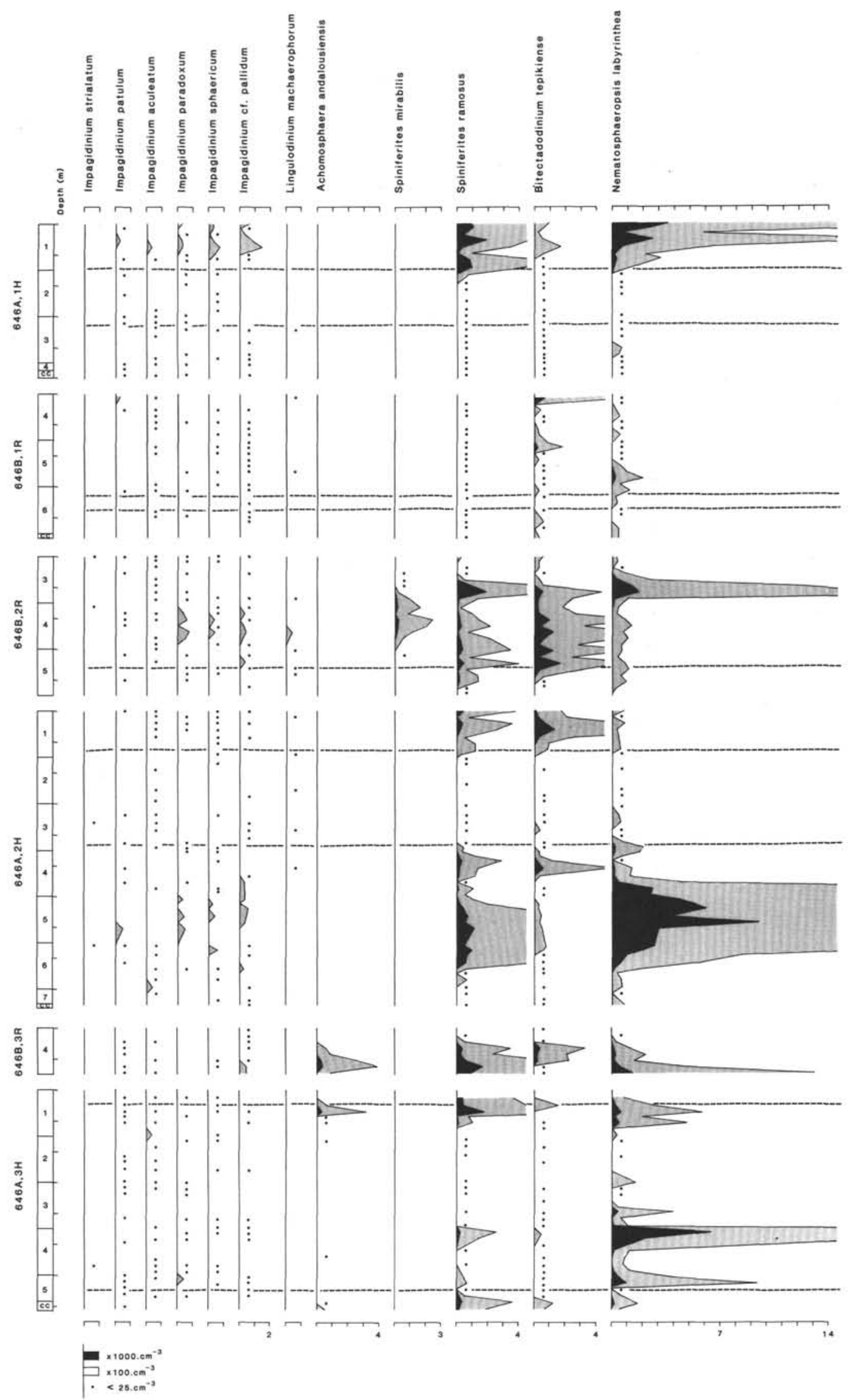

Figure 7. Dinoflagellate cyst concentrations and $\delta^{18} \mathrm{O}$ stratigraphy in the composite sedimentary sequence of Site 646. 

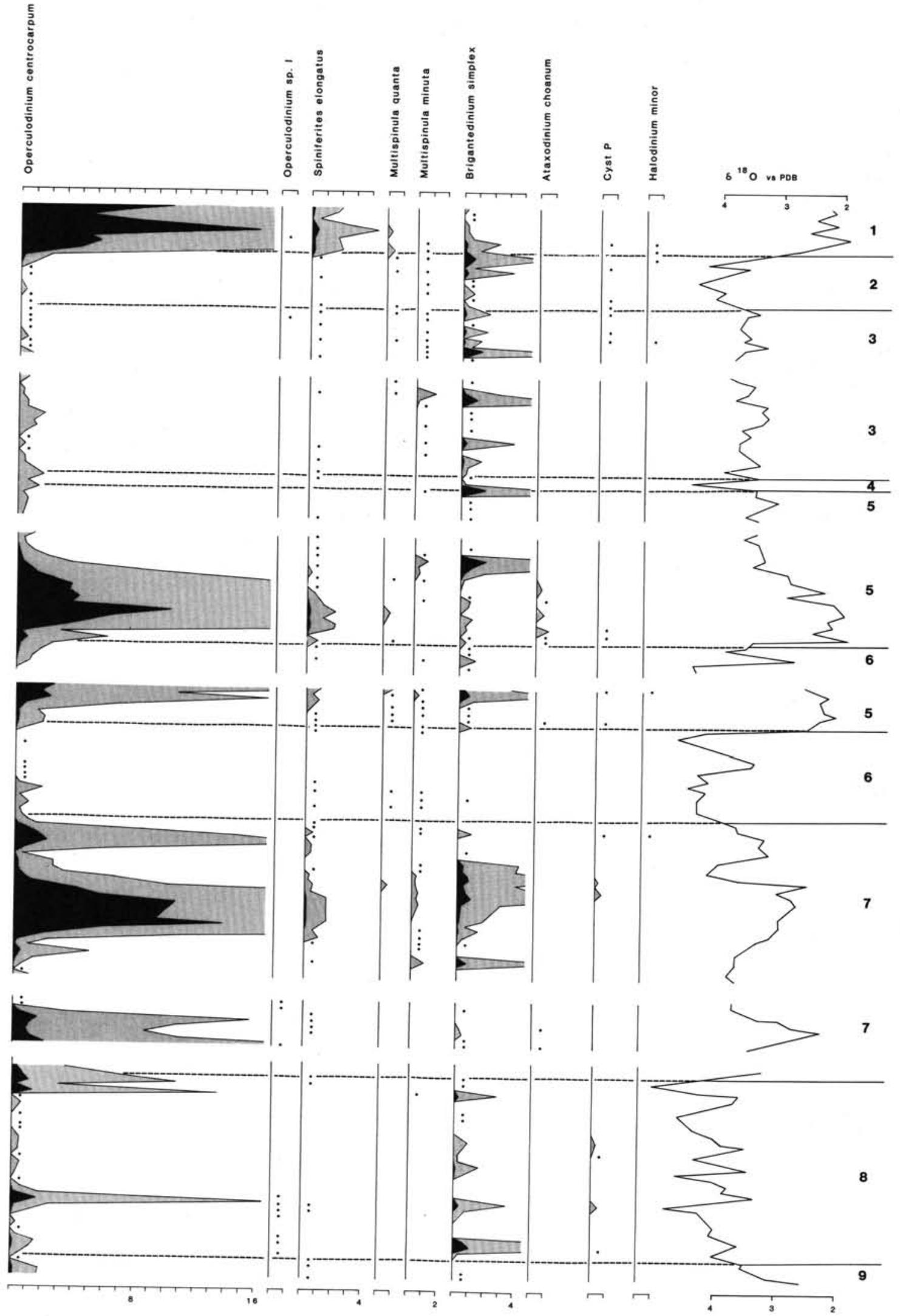

Figure 7 (continued). 

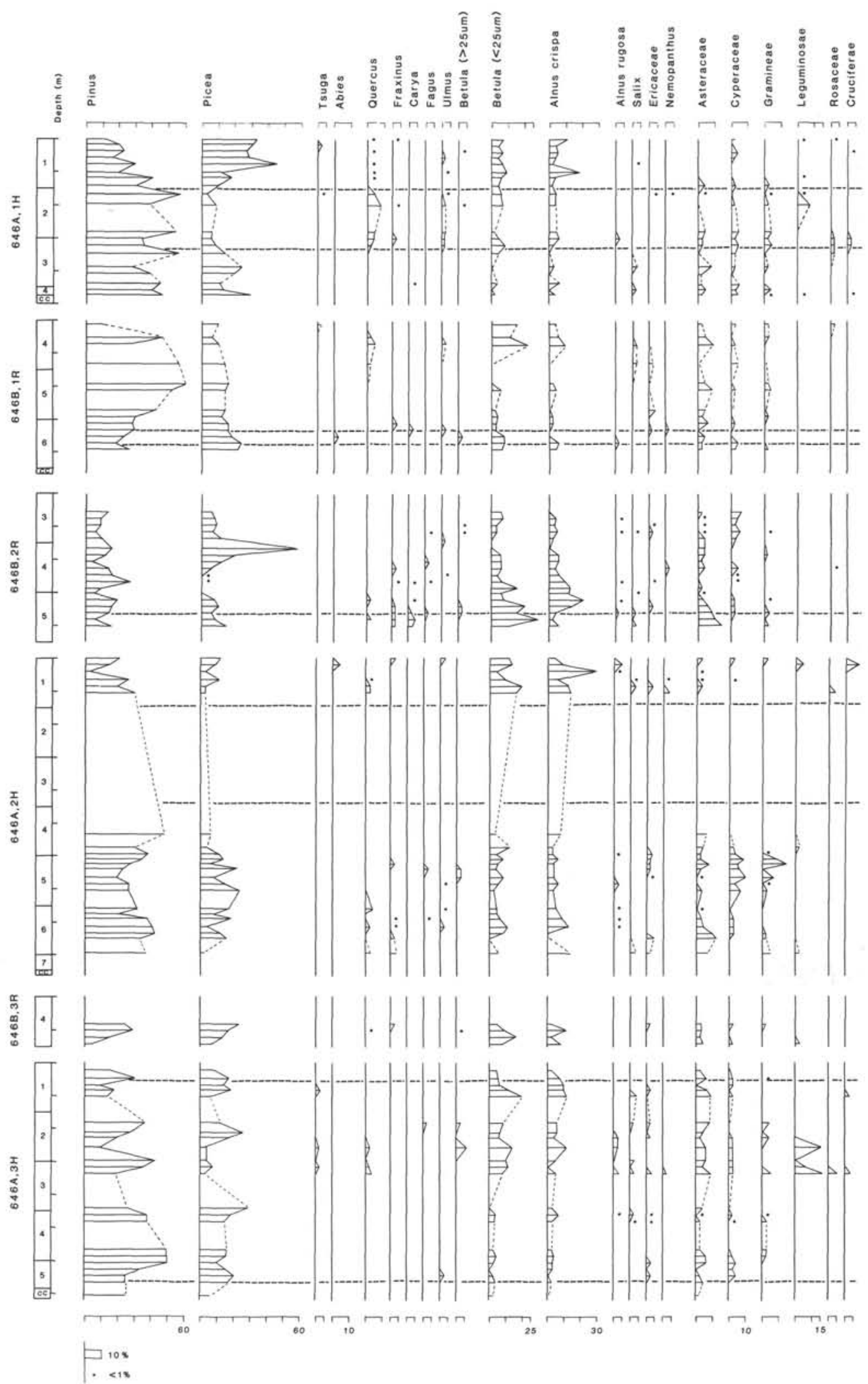

Figure 8. Summary diagram of pollen and spore percentages and $\delta^{18} \mathrm{O}$ stratigraphy in the composite sedimentary sequence of Site 646 . The percentages are based on sums that include all the pollen grains and spores counted. The spectra reported in this diagram consist of sums of $>100$ individuals in most cases; spectra $<50$ individuals are not reported. Several taxa are grouped into genera or family to simplify the diagram. 

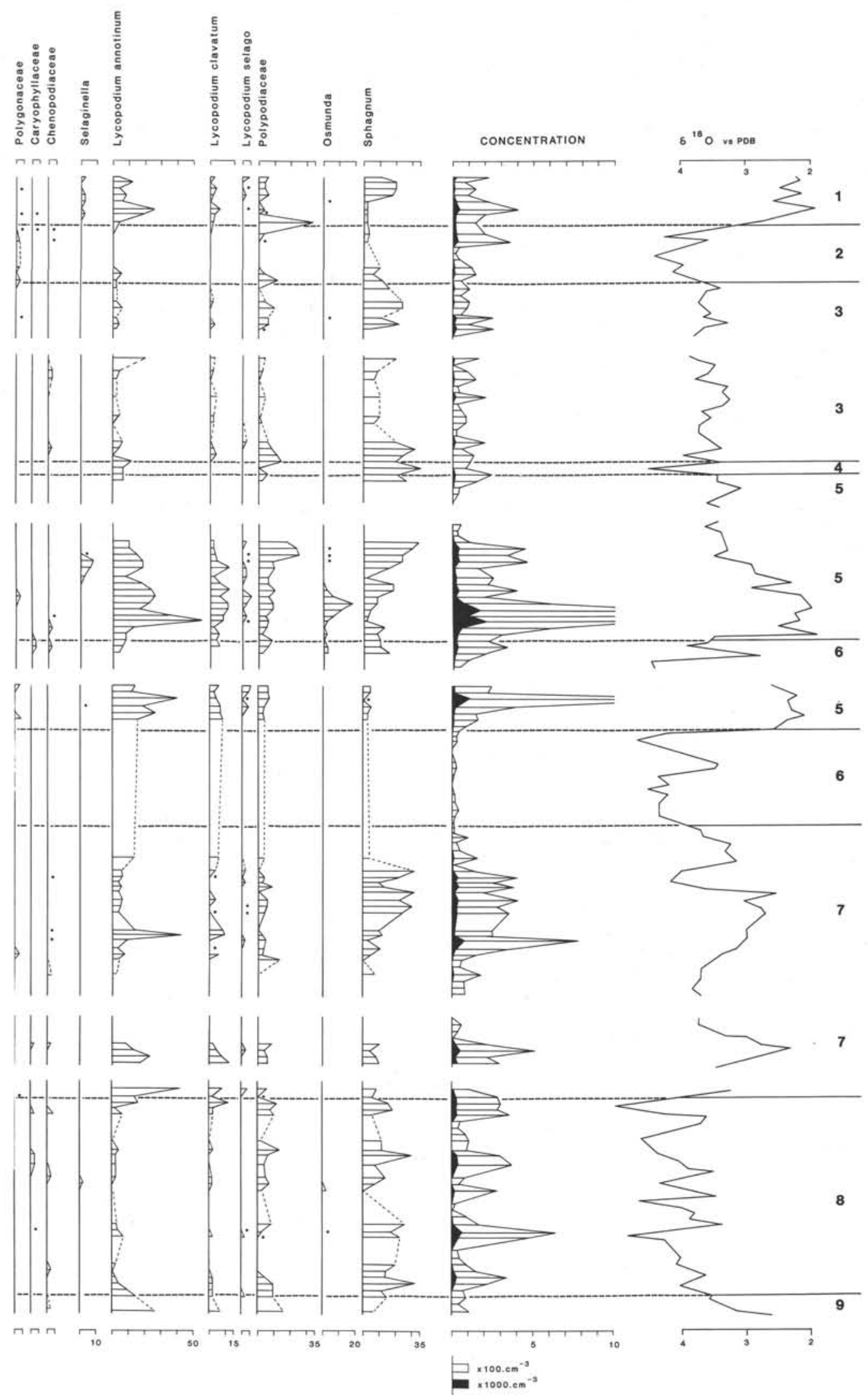

Figure 8 (continued). 
fluxes of southerly air masses into the Labrador Sea during isotopic stage 8 . The flora in isotopic stage 7 is marked by pollen and spore assemblages related to influxes from spruce forest and forest-tundra vegetation. In particular, the middle part of this stage is characterized by an assemblage similar to that observed in the Holocene. Pollen and spores are very rare in sediments correlated with isotopic stage 6 . This probably results from the paucity of vegetation in ice-covered areas onshore and/or the absence of southerly air masses in the eastern Labrador Sea during this time.

Maximum pollen concentrations are recorded in sediments of isotopic substage $5 \mathrm{e}$, indicating high influxes from a dense vegetation. However, the assemblages, which are dominated by Pteridophyte taxa (Lycopodium and Osmunda) and shrub taxa (Betula and Alnus), indicate the existence of large amounts of open shrub tundra in the source area. Data from onshore sections reveal the extension of dense mixed forest in Atlantic Canada during the Sangamonian (substage 5e; de Vernal et al., 1986; Mott and Grant, 1986). The flora observed at Site 646 reflect influxes from several sources: a southerly source contributing Pinus and deciduous tree pollen and a large influx from a shrub tundra-type vegetation. The latter may be attributed to a predominantly westerly air flow into the Labrador Sea, combined with meltwater/fluvial influxes from northern Canada and southern Greenland.

Large changes in pollen and spore assemblages follow the climatic maximum of isotopic stage 5e: a decrease in concentration and increase in Picea percentages are recorded. This trend suggests main air-mass influxes from a southerly source. Palynological data from several cores, including Sites 646 and 647, indicate that isotopic stage 3 is dominated by south-southwest/ north-northeast flowing air masses (de Vernal and Hillaire-Marcel, 1986). Pollen assemblages correlative with the last glacial stage (isotopic stage 2) are dominated by Pinus and characterized by small but significant percentages of deciduous tree taxa (Ulmus and Quuercus), which indicate atmospheric influxes of southern origin. However, many samples from late stage 5 to early stage 2 are almost barren of pollen and spores, indicating intervals of minimum pollen and spore influxes.

\section{Site 647}

A single APC hole (647B) was drilled at Site 647. Recovery during the first five APC cores varied between $95.1 \%$ and $104.3 \%$. Initial foraminifer and stable isotopic results in Hole 647B indicated that the upper $\sim 110 \mathrm{~cm}$ of the mudline core was missing. Data from the Hudson site-survey Core 84-030-003 (see also Scott et al., this volume) were used to splice the missing portion of Hole 647B (Fig. 9). The data are tabulated in Appendix B.

\section{Oxygen Isotopes and Chronostratigraphy}

The oxygen isotopic data for Hole 647B show a typical record extending into isotopic stage 20 (Fig. 9). We were unable to determine isotopic stages below stage 20 because of the lack of independent chronostratigraphic data and two relatively long sections where no samples were available (i.e., intervals 105647B-5H-1, 0-150 cm and 105-647B-6H-1, 0-100 cm). However, we assigned tentative stages 21 through 35 and will explain these further after completion of the benthic foraminifer isotopic record (in progress) for Hole 647B.

The FAD of E. huxleyi was found between Samples 105647B-1H-7, 114-119 cm, and 105-647B-1H-9, 130-132 cm, in Hole 947B (Knuttel et al., this volume), within isotopic stage 7 (Fig. 9). However, studies in the Site 647 survey Core 84-030-003 indicate that the FAD of this taxon occurs within the upper part of isotopic stage 8 (Hearn, 1986). In Hole 647B the LAD of $P$. lacunosa occurs between intervals 105-647B-3H-3, $120-125 \mathrm{~cm}$, and 105-647B-3H-2, 80-85 cm (Knuttel et al., this volume). This datum occurs in approximately the middle of isotopic stage 12 (Fig. 9), which is consistent with the age reported for the LAD of this taxon at about $0.474 \mathrm{Ma}$ (Berggren et al., 1985). The oldest studied sample in Hole 947B lies above the LAD of C. macintyrei (Knuttel et al., this volume).

The Brunhes-Matuyama magnetic chron boundary occurs in isotopic stage 19 (Fig. 9). Detailed paleomagnetic data will be needed to evaluate fully the chronostratigraphy of the older section in this hole.

\section{Planktonic Foraminifers}

Figure 9 shows that downcore planktonic foraminifer plots in Hole 647B exhibit large fluctuations in abundance values. No sample examined in Hole 647B was barren of planktonic foraminifers, and all samples showed $\mathrm{B} / \mathrm{P}$ ratios $<<1$, which suggests that extensive calcium carbonate dissolution did not take place at Site 647 during the last $\sim 1.2 \mathrm{Ma}$. Foraminifer test fragmentation in Hole 647B varies between $10 \%$ and $30 \%$, with occasional spikes reaching $50 \%$ (Fig. 9). Comparison of the test fragmentation with the isotopic and faunal data shows that there is no apparent correlation between the climatic cycles and the preservation of the foraminifer debris on the seafloor. These data suggest that the faunal record in Site 647 experienced little preferential dissolution, and these data together with the very low $\mathrm{B} / \mathrm{P}$ ratios suggest that the fluctuations observed in the total planktonic foraminifer data cannot be explained by dissolution.

Figure 9 shows the percentage of sediment coarser than 63 $\mu \mathrm{m}$ in Hole 647B. This size fraction includes biogenic sediments as well as terrigeneous sand- and gravel-sized debris. In general, there is a good positive correlation between the planktonic foraminifer abundance and the $>63-\mu \mathrm{m}$ fraction, suggesting that the sand fraction is largely controlled by the biogenic influx at the site. Sedimentation rates for individual glacial and interglacial stages were calculated using oxygen-isotope stratigraphy and the chronology of (1) Martinson et al. (1987) for stages 1 through 8, (2) Shackleton and Opdyke (1976) for stages 9 through 18, and (3) Ruddiman et al. (1986a) for stages 19 through 35. The deposition rates in the upper $\sim 33 \mathrm{~m}$ (stages 1 through 19) varied from 8.7 to $2.1 \mathrm{~cm} / \mathrm{k}$.y. in stages 13 and 11 , and from 6.8 and $2.4 \mathrm{~cm} / \mathrm{k} . \mathrm{y}$. in stages 4 and 6 , respectively, with a glacial and interglacial average for each of $4.7 \mathrm{~cm} / \mathrm{k}$.y.. Similar calculations for stages 19 through 35 reveal higher average deposition rates of 6.5 and $5.6 \mathrm{~cm} / \mathrm{k} . \mathrm{y}$. for the interglacial and glacial stages, respectively. An overall sedimentation rate of $4.7 \mathrm{~cm}$ / k.y. for the upper $\sim 33 \mathrm{~m}$ generally supports the rate of $4.5 \mathrm{~cm} /$ k.y. suggested by the magnetostratigraphic data. Thus, temporal variations in sedimentation rate do not appear to be a major factor controlling the downcore fluctuations in total foraminifer abundances in Hole 647B (Fig. 9). Abundance variations in the total planktonic foraminifers largely represent first-order biogenic productivity in the southern Labrador Sea.

Comparison of foraminifer data with the oxygen isotopic curve shows that interglacial isotopic stages $1,5,7$, and 9 have few planktonic foraminifers, while stages $11,13,15,17$, and 19 include abundant foraminifers. Most glacial stages $(2,4,6,8$, $10,12,16)$ have few planktonic foraminifers; but stages 14 and 18 include abundant planktonic foraminifers. In general, the glacial stages are characterized by lower species diversity where the fauna is dominated by $N$. pachyderma (sinistral), with varying percentages of $G$. bulloides, G. quinqueloba, and N. pachyderma (dextral). Interglacial stages are characterized by higher species diversity where the fauna is dominated by $N$. pachyderma (dextral), G. bulloides, G. quinqueloba, and G. inflata, with smaller percentages of $N$. dutertrei, G. tumida, G. uscitula, G. hirsuta, G. crassaformis, G. menardii, and G. truncatu- 
linoides. Several glacial stages, such as $6,8,10,14,18$, also included small peaks of $N$. dutertrei and Globorotalia species.

\section{Dinoflagellates}

The palynostratigraphy of the site-survey Core 84-030-003 for Site 647 is described in detail by de Vernal and Hillaire-Marcel (1987). The salient features can be summarized as follows:

1. Both subarctic and subtropical dinocyst species are present throughout isotopic stages 1 through 8 . Subarctic dinoflagellates are similar to those found in northern Labrador Sea cores (Aksu and Mudie, 1985); subtropical dinoflagellates include mainly Impagidinium spp. (I. patulum, I. aculeatum, I. strialatum, I. paradoxum, and $I$. sphaericum). These data indicate continuous flow of warm surface water into southern Labrador Sea during the past $\sim 0.3 \mathrm{Ma}$.

2. Major changes in total numbers of dinocysts $/ \mathrm{cm}^{3}$ show fluctuations that generally indicate reduced phytoplankton productivity during glacial intervals, although productivity remains relatively high during the early parts of stages 6 and 8 .

3. Total numbers of $O$. centrocarpum, $N$. labyrinthea, Spiniferites spp., and Bitectadodinium tepikiense, the main subarctic water mass indicators in Davis Strait and southern Baffin Bay cores, also have peaks in the early parts of stages 4,6 , and 8 , thus showing good correlation with the dinoflagellate records of Cores 77-027-017, 77-5-1, and 75-009-37 that were studied in northern Labrador Sea, Davis Strait, and eastern Labrador Sea, respectively (Mudie and Aksu, 1984; Aksu and Mudie, 1985; de Vernal, 1986).

\section{Pollen and Spores}

Pollen and spore concentrations are relatively low throughout the southern Labrador Sea cores, as expected from the distance offshore and the pelagic nature of the sediments (Mudie, 1982). Peaks of pollen concentration (mostly Picea) mark the upper parts of interglacial stages 5 and 7; significant numbers of Picea pollen also persist into early parts of glacial stages 4 and 6 . This pattern of the influx of tree pollen is similar to that found in the Davis Strait cores. In Core 84-030-003, a large peak in pollen concentration at the top of isotopic stage 8 reflects increases of both Picea tree pollen and Artemisia shrub and herb pollen.

\section{DISCUSSION}

During the last decade, numerous scientists studied the paleoclimatic and paleoceanographic history of the Labrador Sea (Fillon and Duplessy, 1980; Mudie and Aksu, 1984; Fillon, 1985; Aksu and Mudie, 1985; Fillon and Aksu, 1985; de Vernal and Hillaire-Marcel, 1987), the North Atlantic Ocean (Ruddiman and McIntyre, 1976, 1981a, 1981b; Ruddiman, 1977; Shackleton et al., 1984; Ruddiman et al., 1986b), and the Norwegian and Greenland seas (Kellogg, 1976, 1977). These studies contributed considerable knowledge to our understanding of atmosphere-hydrosphere-cryosphere relationships during the glacial/ interglacial cycles in the Northern Hemisphere. The salient findings of studies in the Labrador Sea are listed as follows:

1. During the summers of early to middle stages of major ice-growth phases, surface waters in the northern Labrador Sea were relatively warm (subpolar) and free of sea ice. A corridor of oceanic warmth apparently extended from the central North Atlantic into the northern Labrador Sea during the early stages of most major late Quaternary glaciations. The existence of an intense thermal gradient between the frigid glaciated continents and warmer ocean provided optimal conditions for ice-sheet growth by contributing a large source of moisture and a mechanism for channelizing the moisture through movement of southerly storms northward into the Labrador Sea (Ruddiman et al., 1980).

2. Later phases of glacial periods were marked by a southerly shift of the Arctic-Atlantic air front and subsequent dominance of the northern Labrador Sea by drier westerly arctic air masses, accompanied by a southerly shift of the subpolar West Greenland Current and extensive year-round sea-ice formation in the Labrador Sea.

3. Transitions from glacial to interglacial periods were marked by the development of a low-salinity surface layer, which was maintained by a continuous supply of meltwater from the decaying ice sheets.

4. Paleoceanographic conditions and atmospheric circulation during the interglacial periods were similar to those observed today.

The oxygen isotopic data from Sites 646 and 647 show that the transitions from glacial to interglacial stages were rapid and were accompanied by equally rapid faunal changes. Figures 10 and 11 summarize the faunal and isotopic data for Holes $646 \mathrm{~A}$ and 646B (composite) and for Hole 647B. The designations of planktonic foraminifer species to ecological water masses follow those described by Ruddiman and McIntyre (1976). These are as follows: polar water $=>>75 \%$ polar species $(N$. pachyderma sinistral); subpolar water $=<75 \%$ subpolar species and $<35 \%$ transitional species ( $G r$. inflata, $N$. dutertrei); transitional water $=>35 \%$ transitional species and $<15 \%$ subtropical species (Gr. hirsuta, Gr. truncatulinoides, Gr. scitula, Gr. crassaformis, Globigerinoides ruber, Gs. conglobatus, and G. rubescens). In both holes no distinction was made between the cold and warm subtropical water masses, simply because the warm subtropical taxa only occur as auxillary species in insignificant quantities.

A north-south ecological water-mass history across the Labrador Sea, reconstructed from the planktonic foraminifer assemblages for Holes 646A, 646B (composite) and 647B (Figs. 10 and 11), is illustrated in Figure 12. The site of Holes 646A and 646B is dominated mainly by a polar water mass with subpolar water masses advecting northward predominantly during the early interglacial stages $5,7,9,11$, and 17 , and with shorter duration penetration of subpolar water masses in stages 15 and possibly 25 . This northward advection is probably related to a current similar to today's West Greenland Current. However, during interglacial stages $1,13,19$, and 21 , planktonic foraminifers indicate dominance by polar water masses throughout the entire duration of the interglacials. These data suggest the absence of the West Greenland Current from Site 646 during these periods. The planktonic foraminifer assemblage in isotopic stage 1 includes up to $20 \%$ subpolar species, which is about $5 \%$ less than the limit for the subpolar water mass (Ruddiman and McIntyre, 1976). Similarly, the dinocysts indicate warm-water advection during isotopic stage 1 . Today, subpolar surface water masses dominate the area of Site 646. Therefore, the ecologic water-mass designations reconstructed using the criteria suggested by Ruddiman and McIntyre (1976) should be regarded as first-order estimates of water masses. In general, Hole 647B is dominated by subpolar water masses with periodic incursions of polar water masses during glacial stages $2,4,6,12,16$, and 22 . Total domination of this site by polar water masses during these periods indicates southward migration of the polar front and increased influence of a cold current similar to today's Labrador Current. Glacial stages $8,10,18,23$, and 26 also show the presence of subpolar water masses during their early periods, which suggests that a corridor of oceanic warmth persisted in the Labrador Sea and was possibly related to the presence of a subpolar 


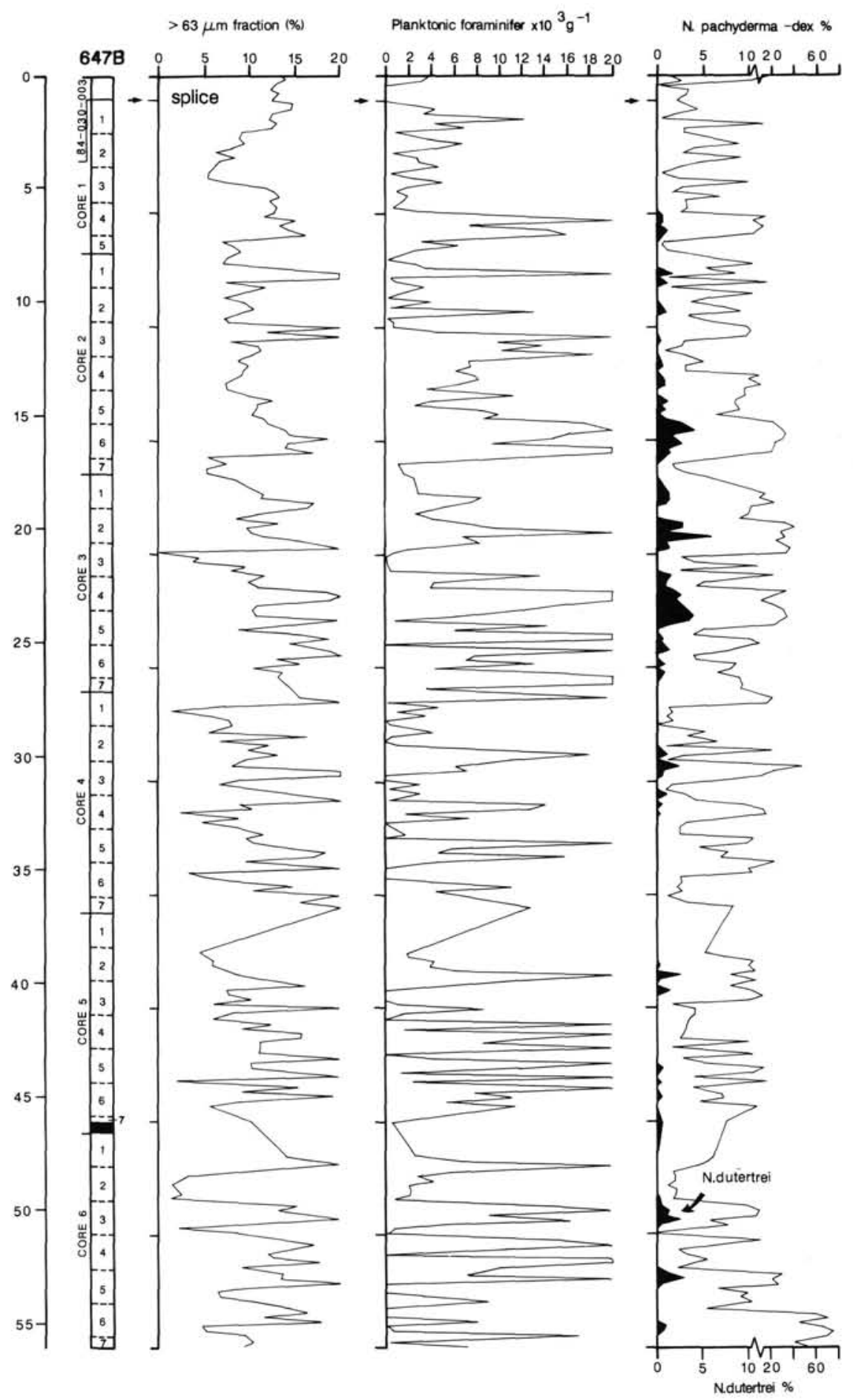

Figure 9. Planktonic foraminifer and oxygen isotopic data in Hole 647B. Detailed comparisons of the faunal and isotopic data of Hole 647B with the site-survey cores revealed that $1.1 \mathrm{~m}$ of sediment was missing at the top of Core 105-647B-1 H; this section is spliced from the site-survey Core 84-030-003 and a trigger-weight core. Stable isotopic data for 84-030-003 are from de Vernal (1986).

gyre between the West Greenland Current and the Labrador Current. The most striking feature of the water mass migration in the area is the spatial continuity observed in both the long intervals of major subpolar water mass migrations (i.e., lower stages 5,9 , and 11 ) and in short-duration intervals (i.e., stages 7 and 17). These features indicate great stability for the oceanic currents in the Labrador Sea. The other prominent aspect of the water migrations is the abrupt terminations of subpolar water masses between $53^{\circ} \mathrm{N}$ and $58^{\circ} \mathrm{N}$.

The areal distribution of water masses in the Labrador Sea cannot be determined with only two sites, simply because of the presence of complex interactions between the Labrador Current, West Greenland Current, and the North Atlantic Drift. The observed water mass migrations reflect north-south migra- 


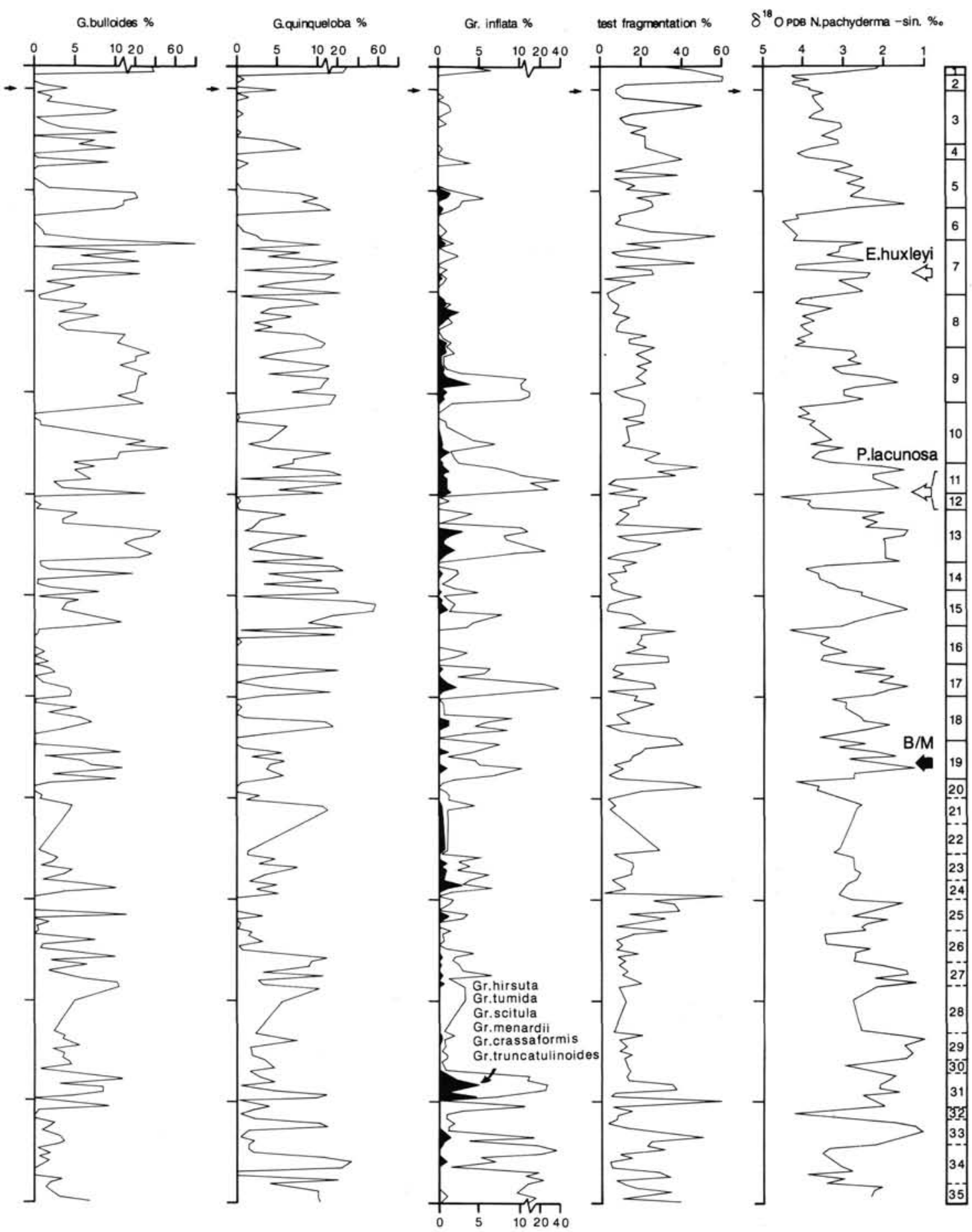

Figure 9 (continued).

tions of water masses and changing patterns of the ocean currents. For example, during isotopic stage 5, data from the southern site (Hole 647B) show subpolar water masses only during the first $\sim 18,000 \mathrm{yr}$ (from $\sim 129,000$ to $111,000 \mathrm{yr}$ b.p.) and for a short period between 84,000 and 80,000 yr b.p. In contrast, data from Site 646 indicate subpolar water masses during most of interglacial stage 5 ( 129,000 to 90,000 yr b.p.), with only two short-duration $(8,000 \mathrm{yr})$ polar water pulses. The persistent presence of subpolar water masses at Site 646 during isotopic stage 5 can be explained by the domination of the West
Greenland Current at this site, compared to greater influence of the Labrador Current at Site 647. Similarly, the presence of the West Greenland Current at Site 646 can be inferred for the early stages of $7,9,11$, and 17 and sporadically in stage 15 . The water mass migrations at Site 647 are probably the result of a complex interplay between the Labrador Current and the North Atlantic Drift. The southward penetration of polar water masses via the Labrador Current during several glacial periods displaced the subpolar or transitional water masses associated with the North Atlantic Drift. In other glacial intervals, the polar water masses 


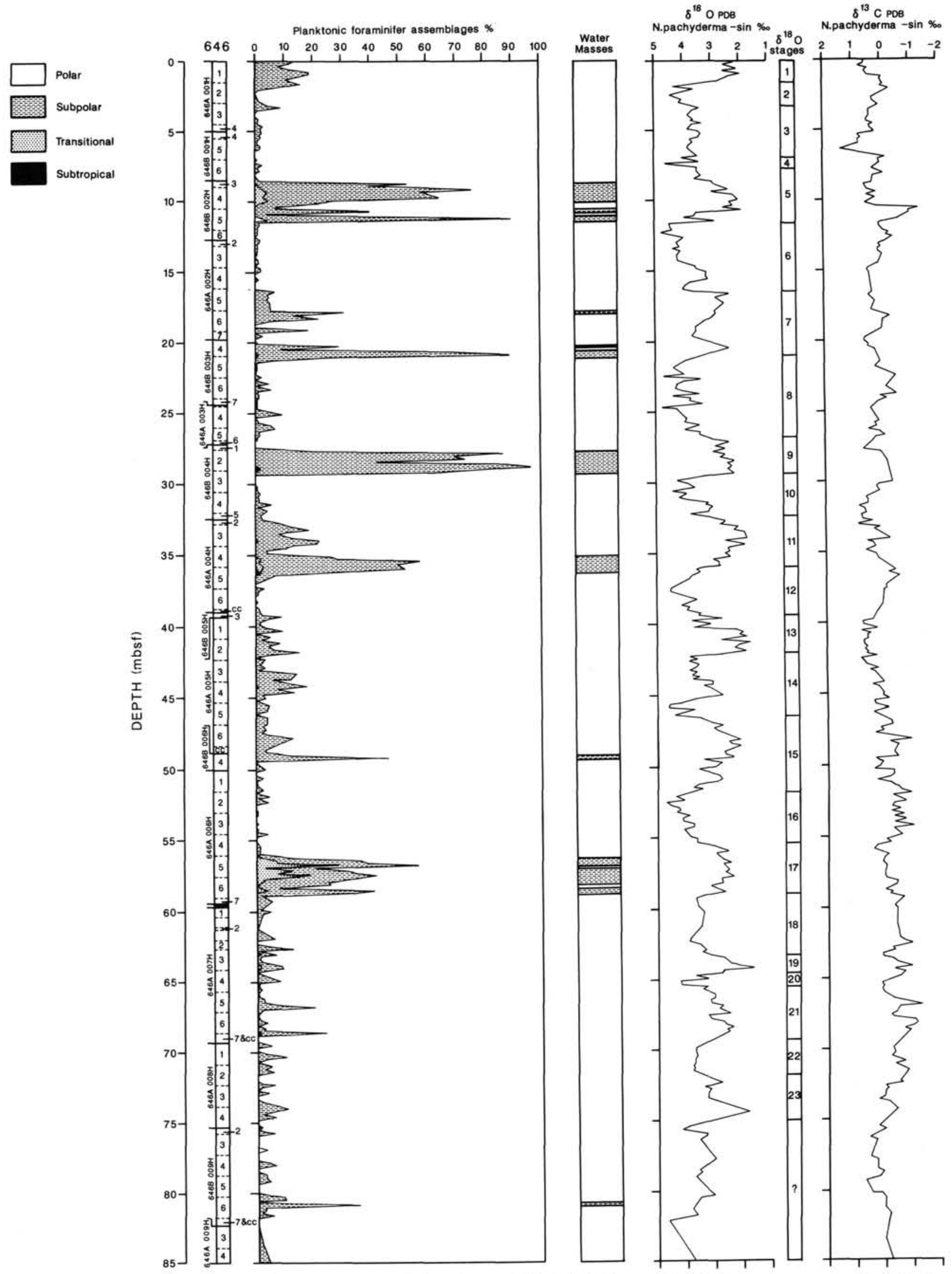

Figure 10. Summary planktonic foraminifer and stable isotopic records for Site 646 (composite). Water masses are reconstructed using the ecological water mass designations of planktonic foraminifers described in Ruddiman and McIntyre (1976). 

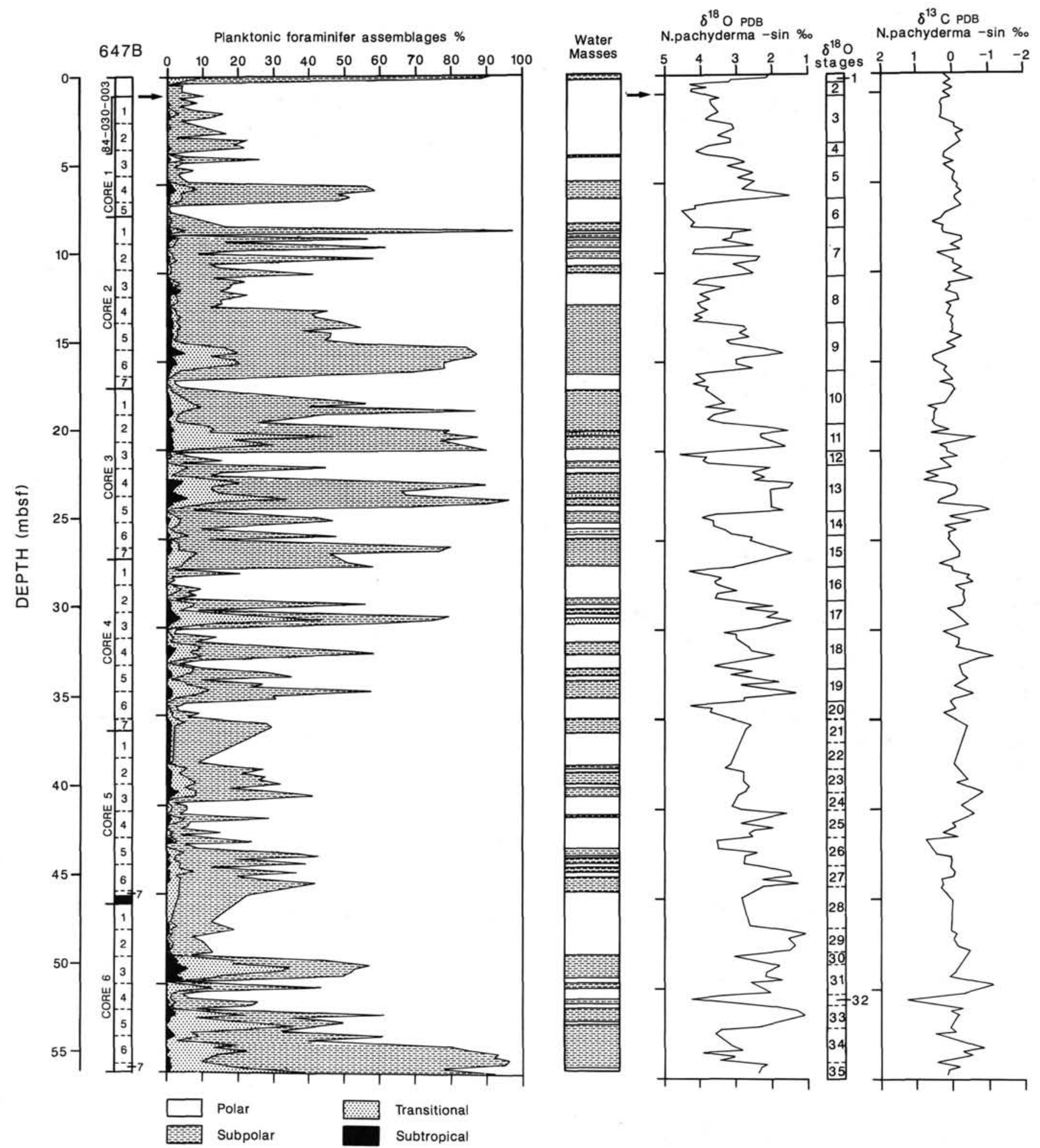

Figure 11. Summary of planktonic foraminifer and stable isotopic records for Site 647. Water masses are reconstructed using the ecological water mass designations of planktonic foraminifers described in Ruddiman and McIntyre (1976).

appear to have been more restricted to the westernmost part of the Labrador Sea and Site 647 was occupied by the North Atlantic Drift.

Site 646 is situated beneath today's subpolar West Greenland Current, with water temperatures in the upper $\sim 100 \mathrm{~m}$ of the water column of $4^{\circ}$ and $9^{\circ} \mathrm{C}$ for February and August, respectively. The uppermost samples in both Holes 646A and 646B and in cores collected during the site-survey cruise include up to $23 \%$ subpolar species. Based on the planktonic foraminifer ecological water mass designations of Ruddiman and McIntyre (1976), these fauna indicate the presence of polar water mass at Site 646. True polar surface waters with $<5^{\circ} \mathrm{C}$ summer temperature generally include more than $90 \%$ polar species; summer surface temperatures in subpolar waters range from $5^{\circ} \mathrm{C}$ to about 


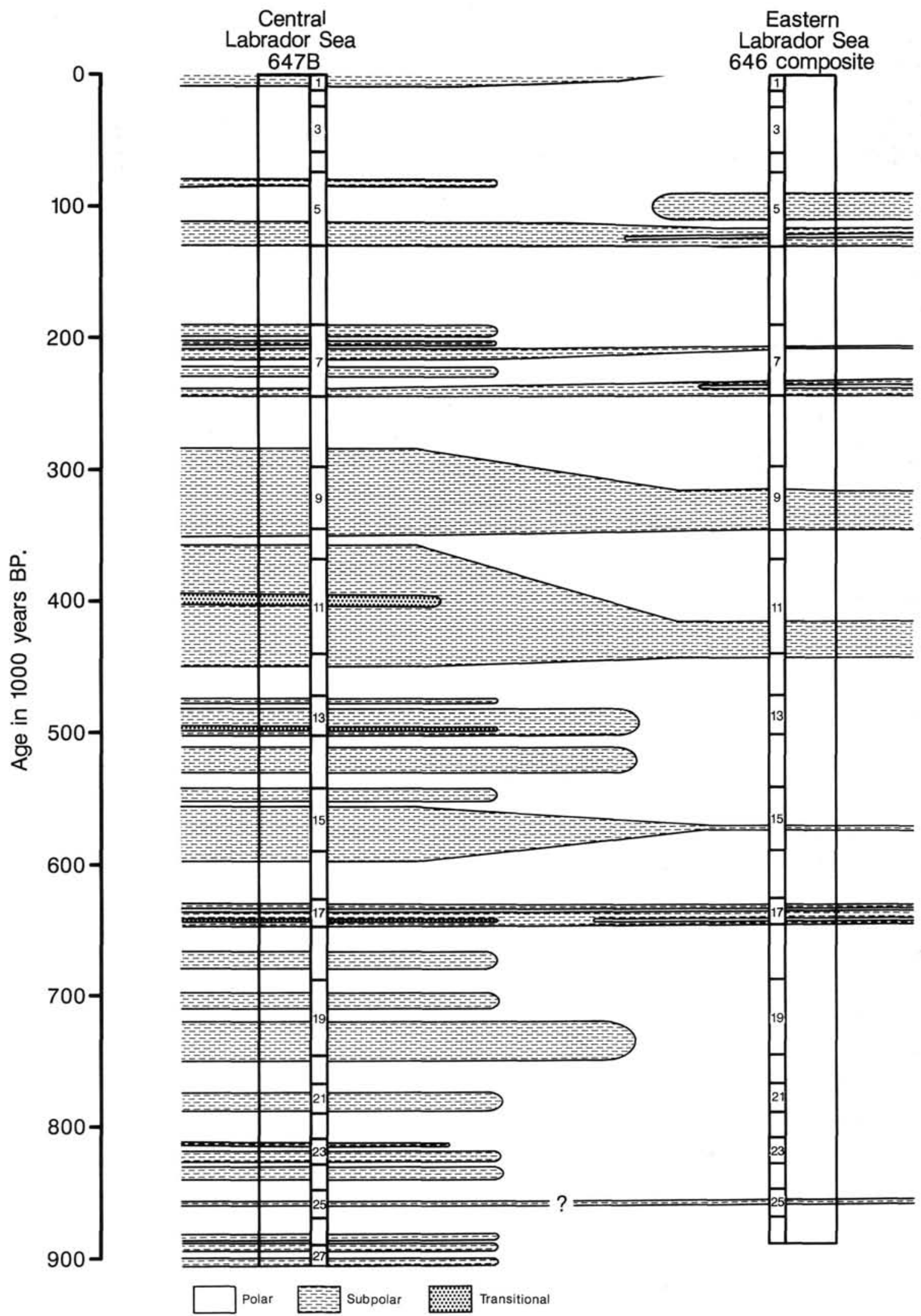

isotopic

stages

11 12,050

2 24,110

3

4 73,910

5

129,840

6

189,610

7

244,180

8

297,000

9

347,000

10367,000

440,000

12

472,000

13

502,000

14

542,000

15

592,000

16

627,000

17647,000

18

688,000

19

745,000

20767,000

21788,500

22808,500

23828,000

24848,000

25869,000

26890,000

27910,000

Figure 12. Ecological water mass movements across a north-south transect in the Labrador Sea. 
$15^{\circ} \mathrm{C}$, with up to about $70 \%$ subpolar species (Tolderlund and Bé, 1971). Water mass determinations using CLIMAP's planktonic foraminifer assemblages and paleoecological transfer functions (Ruddiman and McIntyre, 1976) have limited value in polar and subpolar waters, and one must be careful when distinguishing between ecologically defined water masses and physical oceanographic water masses, as illustrated by the conflicting faunal and floral data from Site 646.

Previous studies with shorter piston cores suggested that the surface waters in the Labrador Sea remained subpolar and free of sea ice during the summers of early glacial stages 6 and 8 (Mudie and Aksu, 1984; Aksu and Mudie, 1985). This interpretation was based primarily on the persistent occurrence of subpolar planktonic foraminifers and the occurrence of warm-water indicator dinoflagellate assemblages in early glacial stages. Foraminifer data from Site 646 show no evidence for subpolar water masses during isotopic stages 6 and 8 (maxima of $<3 \%$ and $<10 \%$ subpolar species, respectively), in contrast to dinoflagellate data that show large peaks in early stage 8 and smaller peaks in early stage 6 . However, data from Site 647 show the presence of subpolar water masses during the early stage 8 , confirming the northward advection of subpolar waters into the northern Labrador Sea. The faunal data in stage 6 of both Sites 646 and 647 show the presence of polar water masses with only up to $10 \%$ subpolar species; whereas the fauna in isotopic stage 6 in the northwestern Labrador Sea cores show subpolar waters with up to $28 \%$ subpolar species. This is perplexing and will require more studies of cores from the western Labrador Sea.

In summary, the data presented here support the paleoceanographic model developed from earlier studies in the Labrador Sea (Mudie and Aksu, 1984; Aksu and Mudie, 1985) and provide a continuous high-resolution paleoclimatic and oceanographic record for the last $\sim 0.9 \mathrm{Ma}$. Continuing studies on coccoliths, stable isotopes in benthic foraminifers, dinoflagellates, pollen and spores, and diatoms with the same set of samples presented here will provide the necessary database to evaluate completely the paleoenvironmental history of the Labrador Sea.

\section{CONCLUSIONS}

Preliminary data for planktonic foraminifers and stable isotopes on $N$. pachyderma sinistral, organic-carbon and nitrogen isotopic data, and palynological data reveal the following salient conclusions:

1. Faunal and stable isotopic records in Sites 646 and 647 provide a $\sim 0.9$-Ma paleoclimatic and paleoceanographic record for the Labrador Sea. At both sites, most glacial stages are generally dominated by polar faunas and floras with low species diversity. Minor occurrences of subpolar species also were observed in the lowermost parts of several glacial stages in Site 646. The fauna suggest the presence of polar ecological water masses in the area during most of the glacial periods. In several glacial stages at Site 647 , the early periods are clearly marked by subpolar and transitional ecological water masses. The interglacials are characterized by polar fauna in Site 646 and polar and transitional fauna in Site 647. However, several interglacial stages in Site 646 include a planktonic foraminifer fauna similar to that found in the glacial stages.

2. The occurrence of subpolar water masses in several glacial isotopic stages indicates significant northward advection of warmer waters into the Labrador Sea during the early glacial periods, which provided a corridor of oceanic warmth that extended from mid- to high latitudes and contributed an additional source of moisture for the continental ice-sheet growth. Similar conditions also were documented in the northwest Labrador Sea (Mudie and Aksu, 1984; Aksu and Mudie, 1985), the Labrador slope and Grand Banks (Alam et al., 1983), and the North Atlantic (Ruddiman et al., 1980).

\section{ACKNOWLEDGMENTS}

Special thanks to the crew and scientific party of ODP Leg 105 and the ODP core curator for assistance in obtaining samples from Hole 647B. Claude Hillaire-Marcel, David J.W. Piper, and D.F. Williams critiqued the manuscript and provided helpful suggestions. This research was supported by NSERC Grant A6896 to A.E. Aksu et al., NSERC Grant A9156 to Hillaire-Marcel, and GSC funding for project 820044 of Mudie. Special thanks to Christopher R. Barnes, Centre for Earth Resources Research, Memorial University of Newfoundland, for providing additional technical support (NSERC Infrastructure Grant A9920 to Barnes et al.) for this project on short notice. The assistance of S. Hookey, E. Hearn, and S. Vatcher for planktonic foraminifer and stable isotopic analyses and C. Goyette and C. Lavergne for palynological analyses is appreciated. Without their help, we would not have been able to finish the study on time. Text figures were drafted by L. Nolan, D. MacNeil, and M. Laithier. This is Centre for Earth Resources Research Contribution No. CERR87-6 and Geological Survey of Canada Contribution No. 53988.

\section{REFERENCES}

Aksu, A. E., 1983. Holocene and Pleistocene dissolution cycles in deepsea cores of Baffin Bay and Davis Strait: paleoceanographic implications. Mar. Geol., 53:331-348.

1985. Planktonic foraminiferal and oxygen isotopic stratigraphy of CESAR cores 102 and 103: preliminary results. Geol. Surv. Can. Pap., 84(22):115-124.

Aksu, A. E., and Mudie, P .J., 1985. Late Quaternary stratigraphy and paleoecology of northwest Labrador Sea. Mar. Micropaleontol., 9: 537-557.

Alam, M., Piper, D.J.W., and Cooke, H.B.S., 1983. Late Quaternary stratigraphy and paleoceanography of the Grand Banks continental margin, eastern Canada. Boreas, 12:253-262.

Andrews, J. T., Shilts, W. W., and Miller, G. H., 1983. Multiple deglaciations of the Hudson Bay Lowlands, Canada, since deposition of the Missinaibi (last-interglacial?) formation. Quat. Res., 19:18-37.

Barry R. G., and Chorley, R. J., 1982. Atmosphere Weather and Climate: London (Methun and Co.).

Berger, W. H., 1970. Planktonic foraminifera: selective dissolution and paleoclimatic interpretation. Deep-Sea Res., 15:31-43.

1979. Preservation of foraminifera. In Foraminiferal Ecology and Paleoecology. Soc. Econ. Paleontol. Mineral., Sh. Cour. 6, Houston.

Berggren, W. A., Kent, D. V., and Van Couvering, J. A., 1985. Neogene geochronology and chronostratigraphy. In Snelling, N. J.(Ed.), The Geochronology and the Geologic Record. Geol. Soc. London Mem., 10:211-260.

Bourgois. J. C., Koerner, R. M., and Alt, B. T., 1985. Airborne pollen: a unique air mass tracer, its influx to the Canadian High Arctic. Ann. Glaciol., 7:109-116.

Denton, G. H., and Hughes, T. J., 1983. Milankovitch theory of ice ages: hypothesis of ice-sheet linkage between regional insolation and global climate. Quat. Res., 20:125-144.

Engstrom, D. R., and Hansen, B.C.S., 1985. Postglacial vegetational change and soil development in southeastern Labrador as inferred from pollen and chemical stratigraphy. Can. J. Botany, 63:543-561.

Fillon, R. H., 1985. Northwest Labrador Sea stratigraphy, sand input and paleoceanography during the last 160,000 years. In Andrews, J. T. (Ed.), Quaternary Environments: Eastern Canadian Arctic, Baffin Bay and West Greenland: Boston, London, Sydney (Allen and Unwin), 210-247.

Fillon, R. H., and Aksu, A. E., 1985. Evidence of sub-polar water masses in Baffin Bay and Labrador Sea during isotopic stage 2. In Andrews, J. T. (Ed.), Quaternary Environments: Eastern Canadian Arctic, Baffin Bay and West Greenland: Boston, London, Sydney (Allen and Unwin), 248-262.

Fillon, R. H., and Duplessy, J. C., 1980. Labrador Sea bio-, tephra- and oxygen isotope stratigraphy and late Quaternary paleoceanographic trends. Can. J. Earth Sci., 17:831-854.

Harland, R., 1983. Distribution maps of recent dinoflagellate cysts in bottom sediments from the North Atlantic Ocean and adjacent seas. Paleontology, 26:321-387.

Hearn, E. M., 1986. Coccolith distribution in the Labrador Sea: a paleoclimatic and paleoceanographic history [B.Sc. thesis]. Memorial Univ. of Newfoundland, Canada. 
Heusser, L. E., 1983. Pollen distribution in the bottom sediments of the western North Atlantic Ocean. Mar. Micropaleontol., 8:77-88.

Kellogg, T. B., 1976. Late Quaternary climatic changes: evidence from deep-sea cores of Norwegian and Greenland Seas. In Cline, R. M., and Hays, J. D. (Eds.), Investigation of Late Quaternary Paleoceanography and Paleoclimatology. Geol. Soc. Am. Mem., 145:77-110.

, 1977. Paleoclimatology and paleoceanography of the Norwegian and Greenland Seas: the last 450,000 years. Mar. Micropaleontol., 2:235-249.

Lamb, H. F., 1980. Late-Quaternary vegetational history of southeastern Labrador. Arctic Alpine Res., 12:117-135.

Lentin, J. K., and Williams, G. L., 1985. Fossil dinoflagelates: index to genera and species. Can. Tech. Rept. Hydrography Ocean Sci., 60, Fisheries and Oceans, Canada.

Martinson, D. G., Pisias, N. G., Hays, J. D., Imbrie, J., Moore, T. C., and Shackleton, N. J., 1987. Age dating and the orbital theory of the ice ages: development of a high-resolution 0 to 300,000 -year chronostratigaphy. Quat. Res., 27:1-29.

Matthews, J., 1969. The assessment of a method for the determination of absolute pollen frequencies. New Phyto., 68:161-166.

Mott, R. J., and Grant, D. R., 1986. Pre-late Wisconsinian paleoenvironments in Atlantic Canada. Géogr. Phys. Quat., 39:239-254.

Mudie, P. J., 1982. Pollen distribution in recent sediment, eastern Canada. Can. J. Earth Sci., 4:709-724.

1985. Palynology of the CESAR cores, Alpha Ridge. In Jackson, H. R., Mudie, P. J., and Blasco, S. M. (Eds.), Initial Geological Report on CESAR-The Canadian Expedition to Study the Alpha Ridge, Arctic Ocean. Geol. Surv. Can. Pap., 84(22):149-174.

Mudie, P. J., and Aksu, A. E., 1984. Paleoclimate of Baffin Bay from 300,000 year record of foraminifera, dinoflagellates and pollen. $\mathrm{Na}$ ture, 312:630-634.

Mudie, P. J., and Short, S. K., 1985. Marine palynology of Baffin Bay. In Andrews, J. T. (Ed.), Quaternary Environments: Eastern Canadian Arctic, Baffin Bay and Western Greenland: Boston, London, Sydney (Allen and Unwin), 263-307.

Richard, P., 1970. Atlas pollinique des arbres et de quelques arbustes indigènes du Québec. Nat. Can., 97:1-34; 97-161; 241-306.

Rousseau, C., 1974. Géographie floristique du Québec-Labrador: Québec (Presses de l'Université Laval).

Ruddiman, W. F., 1977. Investigation of Quaternary climate based on planktonic foraminifera. In Ramsey, A.T.S. (Ed.), Oceanic Micropaleontology, Vol. 1: London, New York, San Francisco (Academic Press), 101-161.

Ruddiman, W. F., and McIntyre, A., 1976. Northeast Atlantic paleoclimatic changes over the past 600,000 years. In Cline, R. M., and Hays, J. D. (Eds.), Investigation of Late Quaternary Paleoceanography and Paleoclimatology. Geol. Soc. Am. Mem., 145:111-146.

, 1981a. Oceanic Mechanism for amplification of the 23,000year ice-volume cycle. Science, 212:617-627.

, 1981b. The North Atlantic Ocean during the last deglaciation. Paleogeogr. Paleoclimatol. Paleoecol., 35:145-214.

Ruddiman, W. F., McIntyre, L. A., Niebler-Hunt, V., and Durazzi, J. T., 1980. Oceanic evidence for the mechanism of rapid northern hemisphere glaciation. Quat. Res., 13:33-64.

Ruddiman, W. F., McIntyre, A., and Raymo, M., 1986a. Matuyama 41,000-year cycles: North Atlantic Ocean and Northern Hemisphere ice sheets. Earth Planet. Sci. Lett., 80:117-129.

Ruddiman, W. F., Shackleton, N. J., and McIntyre, A., 1986b. North Atlantic sea-surface temperatures for the last 1.1 million years. In Summerhayes, C. P., and Shackleton, N. J. (Eds.), North Atlantic Paleoceanography. Geol. Soc. Am. Spec. Publ., 21:155-173.

Ruddiman, W. F., McIntyre, A., and Raymo, M., 1987. Paleoenvironmental results from North Atlantic Sites 607 and 609. In Ruddiman, W. F., Kidd, R. B., and Thomas, E., et al., Init. Repts. DSDP, 94: Washington (U.S. Govt. Printing Office), 855-878.

Shackleton, N. J., and Opdyke, N. D., 1976. Oxygen isotope and paleomagnetic stratigraphy of Pacific core V28-239, late Pliocene to Lat- est Pleistocene. In Cline, R. M., and Hays, J. D. (Eds.), Investigation of Late Quaternary Paleoceanography and Paleoclimatology. Geol. Soc. Am. Mem., 145:449-464.

Shackleton, N. J., Backman, J., Zimmerman, H., Kent, D. V., Hall, M. A., et al., 1984. Oxygen isotope calibration of the onset of icerafting and history of glaciation in the North Atlantic region. $\mathrm{Na}$ ture, 307:620-623.

Srivastava, S. P., Arthur, M., et al., 1987. Proc. ODP, Init. Repts., 105: College Station, TX (Ocean Drilling Program).

Thunell, R. C., 1976. Calcium carbonate dissolution in Late Quaternary deep-sea sediments, Western Gulf of Mexico. Quat. Res., 6: 281-297.

Tolderlund, D. S., and Bé, A.W.H., 1971. Seasonal distribution of planktonic foraminifera in the western North Atlantic. Micropaleontology, 17:297-329.

Turon, J.-L., 1984. Le palynoplancton dans l'environment actuel de l'Atlantique nord oriental. Evolution climatique et hydrologique depuis le dernier maximum glaciaire. Mém. Inst. Géol. Bassin Aquit., 17.

Usinger, H., 1975. Pollenanalytische und stratigraphische untersuchungen an zwei Spatglazial-vorkommen in Schleswig-Holstein. Mitteilungen der arbeitsgemeinschaft Geobotanik in Schleswig-Holstein und Hamburg, 25.

de Vernal, A., 1986. Analyses palynologiques et isotopiques de sediments de la mer du Labrador et de la baie de Baffin: éléments d'une climatostratigraphie du Quaternaire supérieur dans l'est du Canada [Ph.D. dissert.]. Université de Montréal, Canada.

de Vernal, A., Causse, C., Hillaire-Marcel, C., Mott, R. J., and Occhietti, S., 1986. Palynostratigraphy and Th/U ages of upper Pleistocene interglacial and interstadial deposits on Cape Breton Island, eastern Canada. Geology, 14:554-557.

de Vernal, A., and Hillaire-Marcel, C., 1986. Paléoenvironments du Wisconsinien moyen dans l'est du Canada par l'analyse palynologique et isotopique de séquence sedimentaires continentales et océaniques: quelques aspects. Rev. Dyn. Géogr. Phys., 27:119-130.

de Vernal, A., and Hillaire-Marcel, C., 1987. Elément d'une climatostratigraphie du Pléistocene moyen et supérieur dans l'est du Canada par l'analyse palynologique et isotopique du forage 84-030-003, mer du Labrador. Can. J. Earth Sci.,

de Vernal, A., Larouche, A., and Richard, P.J.H., 1987. Evaluation of the palynomorph concentrations: do the aliquot and the marker grain methods yield comparable results?. Pollen Spores, 29:291-304.

Date of initial receipt: 20 July 1987.

Date of acceptance: 16 December 1987. Ms 105B-140

\section{APPENDIX A}

ODP Holes 646A and 646B composite of foraminifer and stable isotopic data. $\mathrm{PF}, \mathrm{BF}=$ planktonic and benthic foraminifers per dry weight sediment, respectively; N.p-s, N.p-d $=N$. pachyderma sinistral and dextral, respectively; Gr.i = G. inflata; G.b = G. bulloides; Ga.u $=G$. uvula and $G$. glutinata; G.q $=$ G. quinqueloba; test $=$ foraminifer test fragmentation; $\delta^{18} \mathrm{C}$ and $\delta^{18} \mathrm{O}=$ carbon and oxygen isotopic values in $N$. pachyderma sinistral.

\section{APPENDIX B}

Foraminifer and stable isotopic data for ODP Hole 647B. PF, BF = planktonic and benthic foraminifers per dry weight sediment, respectively; N.p-s, N.p-d = N. pachyderma sinistral and destral, respectively; N.d = N. dutertrei; G.b = G. bulloides; G.q = G. quinqueloba; Gr.i $=G$. inflata $;$ Gr.sp = G. tumida, G. scitula, G. hirsuta, G. crassaformis, G. tenardii, and $G$. truncatulinoides; $\mathrm{Ga} \cdot \mathrm{u}=G$. uvula and $G$. glutinata; test $=$ foraminifer test fragmentation; $\delta^{18} \mathrm{O}$ and $\delta^{13} \mathrm{C}=$ oxygen and carbon isotopic values in N. pachyderma sinistral. 
APPENDIX A.

ODP Hole 646A and 646B (composite). Foraminiferal and stable isotopic data. PF, BF (planktonic and benthic foraminifers per dry weight sediment, respectively), N.p-s, N.p-d (N. pachyderma sinistral and dextral, respectively), Gr.i (Gr. inflata), G.b (G. bulloides), Ga.u (Ga. uvula and Ga. glutinata), G.q (G. quinqueloba), test (foraminiferal test fragmentation), $\delta^{13} \mathrm{C}$ and $\delta^{18} \mathrm{O}$ (carbon and oxygen isotopic values in $N$. padchyderma sinistral).

\begin{tabular}{|c|c|c|c|c|c|c|c|c|c|c|c|c|}
\hline $\begin{array}{l}\text { depth } \\
\text { (mbsf) }\end{array}$ & $\begin{array}{c}>63 \mu \mathrm{m} \\
(8)\end{array}$ & $\begin{array}{c}\text { PF } \\
\text { per g }\end{array}$ & $\begin{array}{l}\text { BF } \\
\text { per } g\end{array}$ & $\underset{\left(\frac{8}{8}\right)}{\text { N.p-s }}$ & $\underset{(\%)}{\text { N.p-d }}$ & $\begin{array}{l}\text { Gr.i } \\
(\%)\end{array}$ & $\begin{array}{l}\text { G.b } \\
(q)\end{array}$ & $\begin{array}{l}\text { Ga.u } \\
(8)\end{array}$ & $\begin{array}{l}\text { G.q } \\
(q)\end{array}$ & $\begin{array}{l}\text { test } \\
(\%)\end{array}$ & ${ }_{\%}^{\delta^{13} \mathrm{C}}$ & $\delta_{00}^{180}$ \\
\hline 0.00 & 1.80 & 185.00 & 4.80 & 85.63 & 1.44 & 0.00 & 7.76 & 0.29 & 4.89 & 15.40 & 0.55 & 2.24 \\
\hline 0.20 & 1.60 & 1000.00 & 22.00 & & 2.86 & 0.00 & 4.85 & 0.22 & 4.19 & & 0.56 & 2.13 \\
\hline 0.40 & 1.00 & 200.00 & 4.80 & 91.76 & 3.23 & 0.00 & 3.58 & 1.08 & 0.36 & 32.00 & 0.75 & 2.49 \\
\hline 0.60 & 1.23 & 1015.00 & 28.90 & 89.21 & 2.04 & 0.00 & 4.48 & 0.81 & 2.85 & 19.00 & 0.47 & 2.01 \\
\hline 0.80 & 0.79 & 1075.00 & 223.20 & 81.02 & 7.46 & 0.00 & 2.39 & 2.03 & 7.12 & 45.00 & 0.55 & 2.59 \\
\hline 1.00 & 0.85 & 999.10 & 7.40 & 81.19 & 5.45 & 0.00 & 3.96 & 1.48 & 7.67 & 13.50 & 0.40 & 1.80 \\
\hline 1.20 & 1.23 & 361.80 & 37.30 & 86.81 & 4.08 & 0.00 & 3.84 & 0.72 & 4.56 & 22.70 & -0.75 & 2.40 \\
\hline 1.45 & 0.70 & 120.20 & 7.50 & 88.94 & 1.15 & 0.00 & 3.23 & 0.00 & 6.68 & 24.60 & -0.04 & 2.70 \\
\hline 1.60 & 4.43 & 1514.30 & 14.30 & 93.02 & 0.57 & 0.00 & 0.57 & & & 8.60 & -0.13 & 3.32 \\
\hline 1.95 & 7.40 & 2445.90 & 12.70 & 91.45 & 1.81 & 0.00 & 1.30 & 0.26 & 5.18 & 20.40 & -0.05 & 4.30 \\
\hline 2.15 & 7.00 & 1750.50 & 15.00 & 98.85 & 0.00 & 0.00 & 0.00 & 0.00 & 1.15 & 30.50 & -0.18 & 3.55 \\
\hline 2.30 & 2.12 & 1.20 & 0.00 & 100.00 & 0.00 & 0.00 & 0.00 & 0.00 & 0.00 & & -0.15 & 3.95 \\
\hline 2.50 & 5.24 & 505.50 & 5.20 & 99.48 & 0.52 & 0.00 & 0.00 & 0.00 & 0.00 & & 0.04 & 4.42 \\
\hline 2.70 & 6.42 & 814.10 & 23.50 & 98.84 & 0.58 & 0.00 & 0.00 & 0.00 & 0.58 & 45.50 & 0.30 & 4.15 \\
\hline 2.95 & 2.22 & 1120.80 & 11.30 & 98.32 & 1.62 & 0.00 & 0.00 & 0.00 & 0.00 & 26.60 & 0.20 & 4.08 \\
\hline 3.15 & 10.00 & 50600.75 & 945.90 & 95.82 & 0.33 & 0.00 & 1.00 & 0.33 & 2.51 & 19.10 & 0.05 & 3.93 \\
\hline 3.40 & 5.00 & 13075.30 & 196.60 & 90.83 & 0.75 & 0.00 & 4.06 & 0. & 4.21 & & 0.29 & 3.45 \\
\hline 3.55 & 4.00 & 1382.00 & 6.70 & 99.03 & 0.49 & 0.00 & 0.49 & 0.00 & 0.00 & 26.70 & 0.38 & 3.60 \\
\hline 3.75 & 2.20 & 142.80 & 1.30 & 100.00 & 0.00 & 0.00 & 0.00 & 0.00 & 0.00 & 61.40 & 0.40 & 3.72 \\
\hline 4.00 & 3.27 & 44.90 & 0.60 & 100.00 & 0.00 & & 0.00 & 0.00 & 0.00 & & 0.43 & 3.75 \\
\hline 4.20 & 1.24 & 139.90 & 1.80 & 98.73 & 1.27 & 0.00 & 0.00 & 0.00 & 0.00 & 61 & 0.47 & 3.65 \\
\hline 4.30 & 1.89 & 340.00 & 6.00 & 98.92 & 1.08 & 0.00 & 0.00 & 0.00 & 0.00 & 61.00 & 0.45 & 3.70 \\
\hline 4.48 & 2.25 & 996.00 & 16.10 & 98. & 1.08 & 0.00 & 0.00 & 0.00 & 0.00 & 52.20 & 0.25 & 3.45 \\
\hline 4.70 & 4.00 & 441010 & 86.10 & 97. & 1.95 & 0.00 & 0.00 & 0.00 & 0.49 & 32.30 & 0.40 & 3.67 \\
\hline 4.90 & 4.15 & 3408.10 & 29.00 & 98.01 & 1.99 & 0.00 & 0.00 & 0.00 & 0.00 & 24.10 & 0.35 & 3.77 \\
\hline 5.14 & 15.00 & 2407.75 & 8.85 & 97.79 & 1.84 & 0.00 & 0.18 & 0.00 & 0.18 & 7.00 & 0.25 & 3.41 \\
\hline 5.35 & 0.84 & 503.11 & 2.41 & 98.56 & 1.44 & 0.00 & 0.00 & 0.00 & 0.00 & 42.60 & 0.76 & 3.32 \\
\hline 5.60 & 5.89 & 1455.92 & 20.22 & 98.26 & 1.56 & 0.00 & 0.00 & 0. & 0.17 & 14 & 0.70 & 3.40 \\
\hline 5.75 & 2.88 & 2080.00 & 9.06 & 99.27 & 0.73 & 0.00 & 0.00 & 0.00 & 0.00 & & 0.78 & 3.72 \\
\hline 5.95 & 0.68 & 1411.76 & 18.82 & 99. & 0.67 & 0.00 & 0.00 & 0.00 & 0.00 & 39.30 & 0.77 & 3.68 \\
\hline 6.17 & 4.98 & 2293.85 & 10.36 & 98.19 & 1.81 & 0.00 & 0.00 & 0.00 & 0.00 & 22.60 & 0.90 & 3.75 \\
\hline 6.38 & 3.00 & 82.20 & 0.00 & 98.21 & 1.79 & 0.00 & 0.00 & 0.00 & 0.00 & 39.30 & 1.35 & 3.82 \\
\hline 6.55 & 3.58 & 3.21 & 0.00 & 100.00 & 0.00 & 0.00 & 0.00 & 0.00 & 0.00 & 50.00 & 0.70 & 3.40 \\
\hline 6.75 & 2.25 & 0.00 & 0.00 & 0.00 & 0.00 & 0.00 & 0.00 & 0.00 & 0.00 & 0.00 & 0.26 & 3.55 \\
\hline 6.95 & 1.62 & 30.41 & 2.64 & 100.00 & 0.00 & 0.00 & 0.00 & 0.00 & 0.00 & 39 & -0.21 & 3.45 \\
\hline 7.12 & 0.99 & 19.39 & 1.27 & 99.49 & 0.51 & 0.00 & 0.00 & 0.00 & 0.00 & 35.35 & 0.04 & 4.04 \\
\hline 7.32 & 1.30 & 19.63 & .61 & 100.00 & 0.00 & 0.00 & 0.00 & 0.00 & 0.00 & 50.00 & 0.00 & 3.41 \\
\hline 7.53 & 2.25 & 56.67 & 4.00 & 97.65 & 2.35 & 0.00 & 0.00 & 0.00 & 0.00 & 57.65 & 0.10 & 4.60 \\
\hline 7.71 & 3.47 & 6448.95 & 30.59 & 99.15 & 8 & 0.00 & 0.00 & 0.00 & 0.00 & 18.69 & 0.29 & 3.46 \\
\hline 7.90 & 7.20 & 3095.78 & 24.28 & 98.56 & 1.44 & 0.00 & 0.00 & 0.00 & 0.00 & 6.07 & 0.17 & 3.49 \\
\hline 8.10 & 4.91 & 2586.30 & 26.30 & 100.00 & 0.00 & 0.00 & 0.00 & 0.00 & 0.00 & 42.20 & -0.16 & 3.39 \\
\hline 8.32 & 4.89 & 309 & 15.44 & 99.25 & 0.50 & 0.00 & 0.00 & 0.25 & 0.00 & 34.16 & 0.26 & 3.41 \\
\hline 8.50 & 2.60 & 2367.27 & 25.45 & 98.62 & 1.23 & 0.00 & 0.00 & 0.00 & 0.15 & 21.00 & 0.29 & 3.57 \\
\hline 8.55 & 1.30 & 1373.93 & 3.50 & 98.20 & 1.80 & 0.00 & 0.00 & 0.00 & 0.00 & 22.70 & 0.30 & 3.31 \\
\hline 8.71 & 2.00 & 97 & 39.20 & 46.70 & 4.80 & 0.00 & 1.70 & 3.00 & 43.90 & 2.50 & 0.32 & 2.93 \\
\hline 8.92 & 1.90 & 4266.67 & 58.99 & 60.14 & 15.21 & 1.38 & 5.88 & 2.31 & .24 & 28.00 & 0.56 & 2.86 \\
\hline 9.20 & 4.88 & 93 & 80.60 & 23.71 & 11.77 & 2.58 & 6.05 & 7.36 & .78 & 14.00 & 0.50 & 2.38 \\
\hline 9.40 & 58 & 93 & 42.56 & 4.48 & 32.97 & 3.75 & 9.34 & 3.29 & 91 & 9.60 & 0.18 & 2.98 \\
\hline 9.60 & 1.50 & 880.60 & 20.15 & 37.07 & 27.46 & 2.56 & 9.84 & 5.95 & 68 & 16.00 & 0.45 & 2.28 \\
\hline 9.80 & 2.80 & & 27.55 & 35.60 & 5 & 3.50 & 6.38 & 2.06 & 32.51 & 7.90 & 0.21 & 2.08 \\
\hline 10.01 & 1.12 & 1018.00 & 28.00 & 73.38 & 1 & 1.19 & 6.48 & 0.00 & 0.93 & 9.90 & 0.35 & 2.03 \\
\hline 10.21 & 0.68 & 340.00 & 24.00 & 78.27 & 14.92 & 0.00 & 2.36 & 0.00 & 4.45 & 20.20 & 0.56 & 2.29 \\
\hline 10.40 & 0.35 & 275.00 & 11.00 & 92.20 & 6.42 & 0.00 & 0.46 & 0.23 & 0.69 & 15.14 & 0.20 & 2.44 \\
\hline 10.54 & 0.2 & 89 & 3.5 & 93.16 & 3.80 & 0.00 & 0.25 & 0.76 & 2.03 & 27.60 & -1.31 & 2.57 \\
\hline 10.72 & 0.38 & 373.00 & 9.00 & 59.04 & 5.58 & 0.00 & 3.85 & 1.54 & 30.00 & 2.90 & -1.00 & 1.90 \\
\hline 10.91 & 0.35 & 218.85 & 5.34 & 96.75 & 1.95 & 0.00 & 0.33 & 0.00 & 0.98 & 15.80 & -1.00 & 3.51 \\
\hline & & & 政 & 52.27 & 6.8 & 0.00 & 2.27 & 22.73 & 18.18 & 4.60 & -0.80 & 3.57 \\
\hline 11.32 & 1.20 & 16.60 & 0.80 & 9.92 & 57.85 & 4.10 & 23.97 & 4.13 & 4.13 & 20.70 & -0.62 & 3.97 \\
\hline 11.51 & & 022.40 & 3.30 & 98.70 & & 0.00 & 0.00 & 0.0 & 0.00 & 10.70 & -0.08 & 2.87 \\
\hline 11.72 & 9.50 & 1160.34 & 9.07 & 98.44 & 56 & & 0.00 & 0.00 & 0.00 & 23.80 & 0.09 & 4.49 \\
\hline 11.91 & 6.35 & 1628,44 & 14.97 & 99.26 & 0.74 & 0.00 & 0.00 & 0.00 & 0.00 & 21.30 & 0.06 & 4.44 \\
\hline & & 1697.87 & 9.10 & 99.20 & 0.80 & 0.00 & 0.00 & 0.00 & 0.00 & 8.90 & -1.01 & 4.34 \\
\hline 12.30 & 4.62 & 2677.82 & 13.39 & 99.17 & 0.83 & & 0.00 & 0.0 & 0.00 & 26.30 & -0.29 & 4.77 \\
\hline 12.51 & 0.23 & 4.00 & 0.10 & 100.00 & 0.00 & 0.00 & 0.00 & 0.00 & 0.00 & 45.70 & -0.18 & 4.26 \\
\hline & & 40.03 & 15.37 & 98.14 & 1.86 & 0.00 & 0.00 & 0.00 & 0.00 & 18.20 & -0.41 & 3.99 \\
\hline 12.80 & 12. & & 4. & & & & 0 . & 0 & & & & \\
\hline & & & & & & & & & & & & \\
\hline .15 & 2 & 4399.50 & 7.90 & 9.14 & .8 & 0.00 & .00 & 0.00 & 0.00 & 53.30 & .05 & 4.14 \\
\hline
\end{tabular}


Appendix A (continued).

\begin{tabular}{|c|c|c|c|c|c|c|c|c|c|c|c|c|}
\hline $\begin{array}{l}\text { depth } \\
\text { (mbsf) }\end{array}$ & $\begin{array}{c}>63 \mu \mathrm{m} \\
(8)\end{array}$ & $\begin{array}{c}\text { PF } \\
\text { per } g\end{array}$ & $\stackrel{\text { BF }}{\text { per } g}$ & $\underset{(8)}{\text { N.p-S }}$ & $\begin{array}{l}\text { N.p-d } \\
(\%)\end{array}$ & $\begin{array}{l}\text { Gr.i } \\
(\%)\end{array}$ & $\begin{array}{l}\text { G.b } \\
(z)\end{array}$ & $\begin{array}{l}\text { Ga.u } \\
(8)\end{array}$ & $\begin{array}{l}\text { G.q } \\
(8)\end{array}$ & $\begin{array}{l}\text { test } \\
(\%)\end{array}$ & $\stackrel{\delta}{13} \mathrm{C}_{0}$ & $\begin{array}{l}\delta^{18} \mathrm{C} \\
/ 00\end{array}$ \\
\hline 30 & 89 & 5 & & & .82 & .00 & 00 & 00 & 0.00 & 0 & 0.00 & 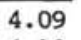 \\
\hline 13.45 & 14.62 & & & & 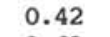 & & & & & & 0.07 & 4.38 \\
\hline 13.63 & 4.03 & & & & 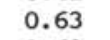 & & & & & & & 4.08 \\
\hline 13.85 & & 0 & 6 & & $?$ & & 00 & .00 & 0.00 & 32.80 & -0.06 & 4.19 \\
\hline 14. & 3 & 20 & 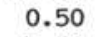 & 100 & & & & & & & -0.03 & 4.18 \\
\hline 14.30 & 5.39 & 1222.60 & .50 & & & & & & & & 0.02 & 4.19 \\
\hline & 3.73 & & 23.60 & 0 & 092 & 00 & 0.00 & .00 & 0.00 & 4.00 & 0.12 & 3.85 \\
\hline 14. & & & & & & & .00 & & 0.00 & & 0.25 & 3.57 \\
\hline 14.80 & 6.49 & 4640.00 & & & & & & & & & & 3.55 \\
\hline 14.95 & 7.50 & 14724.00 & 3.70 & 98. & 1.70 & & & & & & & 3.45 \\
\hline 15.10 & 1.99 & & & & 1.96 & 0.00 & & 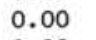 & & & & 3.15 \\
\hline & 0.34 & & & & & & & & 0.00 & & 0.42 & 3.19 \\
\hline & & & & & & & & & 0.00 & & 0.41 & 3.08 \\
\hline 15.80 & 2.79 & & & & & & & & & & & 3.74 \\
\hline 15.99 & 1.2 & 0.40 & 0.00 & 100 & 0 & & & & & & & 3.91 \\
\hline 16. & 8 & 00 & 0.00 & & 0.00 & & 00 & & 0.00 & & 0.36 & 3.92 \\
\hline 16. & 2.2 & & & 100 & & & & & & & & 4.05 \\
\hline 16. & 0. & 1.80 & 0 & & . & & 5 & 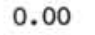 & 0.00 & & 0.35 & 3.67 \\
\hline & & 19.7 & & & 2.86 & & 32 & .00 & 0.00 & & 0.33 & 2.43 \\
\hline 16. & & & & & & & & & & & & 2.89 \\
\hline 17. & .4 & & 6.50 & 95 & 094 & 0.00 & & & & & & 2.74 \\
\hline & & & 90 & & 2.80 & & & & 1.40 & & & 2.57 \\
\hline 17. & .8 & & 1.90 & & 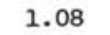 & & 0 & 0 & 4.32 & & 0.34 & 2.89 \\
\hline 17.5 & 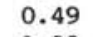 & & & & 5.09 & & & .25 & 2.69 & & 0.11 & 2.86 \\
\hline 18. & 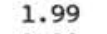 & & & & & & & & & & & 2.94 \\
\hline 18 & .9 & & .20 & 77 & 4.3 & & .00 & 3 & 11.11 & & -0.30 & 3.02 \\
\hline & & & & & & & 44 & 0.00 & 0 & & 0.06 & 3.26 \\
\hline 18.65 & 4.3 & & & & & & & & & & 4 & 3.39 \\
\hline 18 & .0 & 0 & .6 & & 0 & & & & & & -0.02 & 3.49 \\
\hline & & & & & & & & & & & -0.02 & 3.54 \\
\hline 19 & 0 & 2 & & & & & & & 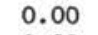 & & & 3.57 \\
\hline 19.5 & .98 & 0 & .50 & & 26 & & & & D & & .38 & 3.61 \\
\hline & 22 & & .40 & & & & & & 0.0 & & 58 & 3.56 \\
\hline 19.9 & $? 0$ & & & & & & & & & & 1 & 3.35 \\
\hline & 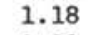 & & 9 & & 0 & & 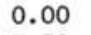 & .00 & 0.0 & & .49 & 3.03 \\
\hline & & & & & & & & 46 & & & .45 & 2.84 \\
\hline 20 & 2 & & & & & 0.0 & 2.8 & & & & 36 & 2.38 \\
\hline & 0 & & & & & & 6 & 0 & & & & 2.69 \\
\hline & & & & & & & & & & & 5 & 3.07 \\
\hline & 0 & 1 & & & 26 & & ) & & & & 3 & 3.25 \\
\hline & 9 & & & & & & & & & & 8 & 3.64 \\
\hline & & & & & & & & & & & 5 & 4.09 \\
\hline 2 & & & & & & & 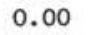 & & 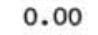 & & 0 & 4.29 \\
\hline & & & & & & & & & 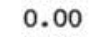 & & -0.03 & 4.29 \\
\hline & & 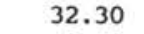 & & & & & & & & 44.00 & -0.57 & 4.70 \\
\hline 27 & & & & & & & & & & & 10 & 3.77 \\
\hline & & & & & & & & & & & & 4.04 \\
\hline & & & & & & & & & & & & 4.23 \\
\hline & 15. & & & & & & & & & & 0 & 4.24 \\
\hline & & & & & & & & & & & -0.16 & 4.27 \\
\hline & & & & & & & & & & & & \\
\hline & & & & & & & & & & & & 2 \\
\hline & & & & & & & & & & & & .43 \\
\hline & & & & & & & & & & & & 3.71 \\
\hline 24.20 & & & & & & & & & & & & 3.84 \\
\hline & & & & & & & & & & & & 3.85 \\
\hline & & & & & & & & & & & & 4.45 \\
\hline & & 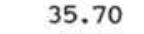 & & & & & & & & & & 4.14 \\
\hline & & & & & & & & & & & & 3.93 \\
\hline & & & & & & & & & & & & \\
\hline 25 & & 1548.8 & & & & & & & & & & 3.80 \\
\hline & & & & & & & & & & & & 3.59 \\
\hline & & & & & & & & & & & & \\
\hline & & & & & & & & & & & & 96 \\
\hline & & & & & & & & & & & & 3.34 \\
\hline 26 & & & & & & & & & & & & .14 \\
\hline & & & & & & & & & & & & 2.80 \\
\hline & & & & & & & & & & & & 2.32 \\
\hline 27.2 & & & & & & & & & & 0.00 & 0.32 & .5 \\
\hline & & & & & & & & & & 0.00 & 0.52 & .89 \\
\hline & & & & & & & & 25 & 70 & 1. & .59 & \\
\hline
\end{tabular}


Appendix A (continued).

\begin{tabular}{|c|c|c|c|c|c|c|c|c|c|c|c|c|}
\hline $\begin{array}{l}\text { depth } \\
\text { (mbsf) }\end{array}$ & $\begin{array}{c}>63 \mu \mathrm{m} \\
(8)\end{array}$ & $\begin{array}{c}\text { PF } \\
\text { per } \mathrm{g}\end{array}$ & $\begin{array}{l}B F \\
\text { per } g\end{array}$ & $\underset{\left(\frac{8}{8}\right)}{\text { N.p-s }}$ & $\underset{\left(\frac{8}{6}\right)}{\text { N.p-d }}$ & $\begin{array}{l}\text { Gr.i } \\
\left(\frac{8}{8}\right)\end{array}$ & $\begin{array}{l}\text { G.b } \\
\left(\frac{q}{\delta}\right)\end{array}$ & $\begin{array}{l}\text { Ga.u } \\
(\%)\end{array}$ & $\begin{array}{l}\text { G.q } \\
\left(\frac{q}{8}\right)\end{array}$ & $\begin{array}{l}\text { test } \\
\left(\frac{8}{8}\right)\end{array}$ & ${ }^{\delta^{13} \mathrm{C}}$ & 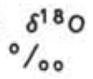 \\
\hline 27.89 & 0.60 & 352.00 & 31.65 & 13.27 & 66.33 & 0.00 & 13.27 & 1.02 & 6.12 & 37.20 & 0.05 & 2.99 \\
\hline 28.10 & 0.59 & 145.00 & 26.71 & 30.67 & 68.00 & 0.00 & 0.00 & 0.00 & 1.33 & 33.33 & -0.03 & 2.67 \\
\hline 28.28 & 0.18 & 2.00 & 12.00 & 26.32 & 73.68 & 0.00 & 0.00 & 0.00 & 0.00 & 21.00 & -0.08 & 2.62 \\
\hline 28.50 & 0.19 & 66.30 & 13.90 & 58.21 & 41.79 & 0.00 & 0.00 & 0.00 & 0.00 & 34.40 & -0.17 & 2.24 \\
\hline 28.71 & 0.23 & 12.30 & 20.50 & 10.96 & 8356 & 0.00 & 2.05 & 1.37 & 2.05 & 32.20 & -0.19 & 2.41 \\
\hline 28.92 & 0.36 & 33.00 & 4.20 & 3.45 & 84.83 & 0.00 & 4.14 & 0.34 & 5.86 & 13.10 & -0.20 & 2.36 \\
\hline 29.19 & 12.59 & 1.78 & 0.00 & 37.50 & 62.50 & 0.00 & 0.00 & 0.00 & 0.00 & 12.50 & -0.25 & 2.31 \\
\hline 29.40 & 10.01 & 0.88 & 0.00 & 100.00 & 0.00 & 0.00 & 0.00 & 0.00 & 0.00 & 16.70 & -0.26 & 2.24 \\
\hline 29.59 & 2.38 & 0.00 & 0.00 & 0.00 & 0.00 & 0.00 & 0.00 & 0.00 & 0.00 & 0.00 & -0.29 & 3.25 \\
\hline 29.80 & 3.20 & 0.00 & 0.00 & 0.00 & 0.00 & 0.00 & 0.00 & 0.00 & 0.00 & 0.00 & -0.32 & 4.04 \\
\hline 30.00 & 2.43 & 145.00 & 7.90 & 100.00 & 0.00 & 0.00 & 0.00 & 0.00 & 0.00 & 36.70 & -0.35 & 3.94 \\
\hline 30.20 & 8.54 & 2632.07 & 62.67 & 99.40 & 0.60 & 0.00 & 0.00 & 0.00 & 0.00 & 13.20 & -0.11 & 3.71 \\
\hline 30.41 & 2.78 & 915.90 & 8.77 & 99.32 & 0.68 & 0.00 & 0.00 & 0.00 & 0.00 & 14.00 & 0.21 & 3.80 \\
\hline 30.70 & 5.22 & 122.90 & 4.33 & 98.55 & 1.24 & 0.00 & 0.00 & 0.00 & 0.21 & 29.00 & 0.13 & 3.97 \\
\hline 30.90 & 3.11 & 2566.71 & 4.19 & 99.18 & 0.82 & 0.00 & 0.00 & 0.00 & 0.00 & 10.30 & 0.45 & 4.08 \\
\hline 31.09 & 15.09 & 5417.43 & 26.56 & 98.77 & 1.23 & 0.00 & 0.00 & 0.00 & 0.00 & 8.09 & 0.60 & 4.10 \\
\hline 31.29 & 6.99 & 4069.00 & 6.72 & 98.66 & 0.50 & 0.00 & 0.00 & 0.00 & 0.84 & 0.80 & 0.56 & 3.99 \\
\hline 31.49 & 2.39 & 2330.31 & 14.30 & 94.68 & 1.84 & 0.00 & 0.51 & 0.20 & 2.76 & 3.58 & 0.51 & 3.26 \\
\hline 31.69 & 4.50 & 2843.19 & 3.76 & 98.94 & 0.92 & 0.00 & 0.00 & 0.00 & 0.13 & 6.20 & 0.80 & 3.05 \\
\hline 31.88 & 3.21 & 3022.38 & 23.29 & 95.86 & 1.45 & 0.00 & 0.29 & 0.00 & 2.41 & 4.60 & 0.51 & 3.26 \\
\hline 32.20 & 6.30 & 2245.00 & 16.52 & 98.54 & 1.46 & 0.00 & 0.00 & 0.00 & 0.00 & 22.60 & 0.60 & 3.82 \\
\hline 32.40 & 1.22 & 2656.00 & 71.26 & 97.32 & 1.61 & 0.00 & 0.50 & 0.00 & 0.57 & 10.00 & 0.75 & 3.10 \\
\hline 32.70 & 1.02 & 6098.00 & 126.00 & 91.70 & 6.50 & 0.00 & 0.22 & 0.22 & 1.12 & 8.97 & 0.71 & 2.68 \\
\hline 32.80 & 1.03 & 2237.00 & 46.00 & 92.78 & 7.22 & 0.00 & 0.00 & 0.00 & 0.00 & 9.79 & 0.70 & 2.55 \\
\hline 32.99 & 1.00 & 1029.00 & 21.00 & 87.94 & 10.95 & 0.00 & 0.00 & 0.19 & 0.93 & 15.77 & 0.59 & 2.75 \\
\hline 33.20 & 0.81 & 745.00 & 32.00 & 81.49 & 14.23 & 0.00 & 0.36 & 0.00 & 3.91 & 9.61 & 0.48 & 2.13 \\
\hline 33.37 & 0.98 & 533.00 & 37.00 & 88.94 & 5.99 & 0.00 & 0.92 & 0.00 & 4.15 & 7.37 & 0.21 & 2.26 \\
\hline 33.57 & 0.39 & 189.00 & 22.00 & 91.67 & 5.80 & 0.00 & 0.36 & 0.00 & 1.09 & 7.25 & 0.75 & 1.88 \\
\hline 33.79 & 0.06 & 9.00 & 1.00 & 86.87 & 6.06 & 0.00 & 1.01 & 0.00 & 6.06 & 19.19 & 0.16 & 1.87 \\
\hline 33.92 & 1.00 & 113.00 & 4.00 & 77.26 & 6.46 & 0.52 & 3.10 & 0.52 & 12.14 & 12.40 & -0.19 & 1.85 \\
\hline 34.18 & 0.54 & 158.00 & 10.00 & 78.38 & 12.61 & 0.00 & 1.80 & 1.25 & 7.21 & 5.41 & -0.09 & 2.57 \\
\hline 34.30 & 1.29 & 446.00 & 15.00 & 86.21 & 6.40 & 0.00 & 0.99 & 0.99 & 5.42 & 12.81 & 0.55 & 2.42 \\
\hline 34.45 & 0.95 & 635.00 & 25.00 & 88.80 & 5.39 & 0.00 & 1.87 & 1.66 & 2.28 & 6.43 & 0.34 & 1.85 \\
\hline 34.68 & 0.82 & 1415.00 & 39.00 & 88.52 & 5.52 & 0.00 & 3.09 & 0.66 & 1.55 & 9.27 & 0.24 & 2.50 \\
\hline 34.88 & 0.70 & 1005.00 & 8.00 & 96.58 & 3.42 & 0.00 & 0.00 & 0.00 & 0.00 & 11.32 & 0.54 & 2.43 \\
\hline 35.08 & 2.63 & 3721.00 & 57.00 & 95.93 & 2.54 & 0.00 & 0.51 & 0.00 & 1.02 & 5.34 & 0.45 & 2.61 \\
\hline 35.29 & 1.92 & 2646.00 & 24.00 & 74.19 & 16.13 & 0.46 & 1.38 & 0.46 & 7.37 & 15.20 & 0.25 & 2.40 \\
\hline 35.44 & 3.61 & 100.00 & 4.00 & 71.13 & 21.30 & 2.11 & 2.11 & 0.00 & 3.52 & 9.15 & 0.17 & 3.00 \\
\hline 35.65 & 0.89 & 310.00 & 12.00 & 42.31 & 28.85 & 1.04 & 13.46 & 2.88 & 10.58 & 17.31 & 0.10 & 2.79 \\
\hline 35.80 & 1.02 & 365.00 & 9.00 & 50.37 & 11.19 & 2.61 & 7.09 & 2.24 & 26.49 & 4.48 & 0.03 & 2.80 \\
\hline 35.97 & 1.05 & 462.00 & 8.00 & 48.10 & 2.89 & 1.73 & 22.15 & 4.15 & 14.18 & 3.81 & -0.13 & 2.75 \\
\hline 36.07 & 1.09 & 1052.00 & 55.00 & 62.84 & 6.28 & 0.55 & 12.02 & 1.64 & 5.85 & 7.92 & -0.24 & 3.42 \\
\hline 36.20 & 1.11 & 537.00 & 6.00 & 58.33 & 6.25 & 0.00 & 9.38 & 2.08 & 23.96 & 10.42 & -0.31 & 3.59 \\
\hline 36.40 & 14.03 & 39,00 & 5.00 & 93.24 & 0.00 & 0.00 & 1.35 & 0.00 & 5.41 & 21.62 & -0.26 & 3.55 \\
\hline 36.58 & 11.00 & 351.00 & 2.00 & 94.86 & 1.93 & 0.00 & 0.64 & 0.00 & 2.57 & 31.83 & -0.35 & 3.74 \\
\hline 36.78 & 14.99 & 7.00 & 2.00 & 97.67 & 2.33 & 0.00 & 0.00 & 0.00 & 0.00 & 16.28 & -0.55 & 3.86 \\
\hline 36.94 & 13.55 & 0.00 & 0.00 & 100.00 & 0.00 & 0.00 & 0.00 & 0.00 & 0.00 & 50.00 & -0.44 & 3.97 \\
\hline 37.17 & 6.29 & 0.00 & 0.00 & 0.00 & 0.00 & 0.00 & 0.00 & 0.00 & 0.00 & 0.00 & -0.25 & 4.14 \\
\hline 37.28 & 6.30 & 4.00 & 2.00 & 97.06 & 2.94 & 0.00 & 0.00 & 0.00 & 0.00 & 35.29 & -0.17 & 4.26 \\
\hline 37.48 & 1.26 & 400.00 & 5.00 & 98.75 & 1.25 & 0.00 & 0.00 & 0.00 & 0.00 & 29.10 & -0.09 & 4.50 \\
\hline 37.59 & 6.85 & 525.00 & 8.00 & 99.05 & 0.95 & 0.00 & 0.00 & 0.00 & 0.00 & 27.13 & -0.10 & 4.55 \\
\hline 37.69 & 4.99 & 53.00 & 3.00 & 98.87 & 1.13 & 0.00 & 0.00 & 0.00 & 0.00 & 6.21 & -0.05 & 4.50 \\
\hline 37.90 & 2.91 & 0.00 & 0.00 & 0.00 & 0.00 & 0.00 & 0.00 & 0.00 & 0.00 & 0.00 & 0.02 & 4.26 \\
\hline 38.05 & 5.20 & 7.00 & 8.00 & 100.00 & 0.00 & 0.00 & 0.00 & 0.00 & 0.00 & 22.54 & 0.01 & 3.98 \\
\hline 38.24 & 4.84 & 6500.00 & 36.00 & 99.44 & 0.56 & 0.00 & 0.00 & 0.00 & 0.00 & 12.85 & -0.01 & 3.57 \\
\hline 38.47 & 15.00 & 1.00 & 0.00 & 100.00 & 0.00 & 0.00 & 0.00 & 0.00 & 0.00 & 4.76 & 0.00 & 3.88 \\
\hline 38.66 & 8.80 & 4857.00 & 36.00 & 99.07 & 0.75 & 0.00 & 0.00 & 0.00 & 0.19 & 21.49 & 0.05 & 4.20 \\
\hline 38.80 & 9.98 & 3915.00 & 22.00 & 99.18 & 0.82 & 0.00 & 0.00 & 0.00 & 0.00 & 18.14 & 0.07 & 3.83 \\
\hline 38.98 & 8.84 & 4511.00 & 42.00 & 98.37 & 1.63 & 0.00 & 0.00 & 0.00 & 0.00 & 7.21 & 0.15 & 4.00 \\
\hline 39.00 & 7.73 & 394.00 & 7.00 & 97.78 & 2.22 & 0.00 & 0.00 & 0.00 & 0.00 & 11.67 & 0.22 & 3.32 \\
\hline 39.20 & 10.95 & .5578 .00 & 208.00 & 98.00 & 2.00 & 0.00 & 0.00 & 0.00 & 0.00 & 13.00 & 0.25 & 3.48 \\
\hline 39.30 & 4.00 & 200.00 & 5.00 & 90.79 & 3.95 & 0.00 & 0.00 & 0.00 & 5.26 & 10.53 & 0.27 & 3.57 \\
\hline 39.50 & 4.80 & 418.00 & 4.00 & 96.04 & 2.64 & 0.00 & 0.44 & 0.00 & 0.88 & 18.50 & 0.30 & 2.75 \\
\hline 39.70 & 8.06 & 1573.00 & 6.00 & 97.81 & 1.59 & 0.00 & 0.00 & 0.00 & 0.60 & 3.58 & 0.39 & 3.82 \\
\hline 39.91 & 3.10 & 3064.00 & 25.00 & 98.35 & 1.24 & 0.00 & 0.00 & 0.00 & 0.41 & 10.74 & 0.75 & 3.07 \\
\hline 40.10 & 1.59 & 1963.00 & 6.00 & 96.37 & 0.66 & 0.00 & 1.32 & 0.66 & 0.99 & 11.55 & 0.72 & 3.87 \\
\hline 40.33 & 1.68 & 1879.00 & 19.00 & 90.37 & 1.66 & 1.33 & 3.32 & 0.00 & 3.32 & 15.61 & 0.30 & 2.24 \\
\hline 40.50 & 1.03 & 673.00 & 9.00 & 99.56 & 0.44 & 0.00 & 0.00 & 0.00 & 0.00 & 31.56 & 0.82 & 1.96 \\
\hline 40.70 & 1.80 & 1066.00 & 5.00 & 94.66 & 3.88 & 0.00 & 0.49 & 0.00 & 0.97 & 22.33 & 0.56 & 2.14 \\
\hline 40.80 & 1.92 & 2361.00 & 29.00 & & & 0.00 & 0.00 & 0.00 & 0.00 & 16.77 & 0.60 & 1.79 \\
\hline 41.00 & 3.13 & 1796.00 & 20.00 & 98.29 & 1.71 & 0.00 & 0.00 & 0.00 & 0.00 & 28.41 & 0.59 & 2.79 \\
\hline
\end{tabular}


Appendix A (continued).

\begin{tabular}{|c|c|c|c|c|c|c|c|c|c|c|c|c|}
\hline $\begin{array}{l}\text { depth } \\
\text { (mbsf) }\end{array}$ & $\begin{array}{c}>63 \mu \mathrm{mm} \\
(8)\end{array}$ & $\begin{array}{c}\text { PF } \\
\text { per } g\end{array}$ & $\begin{array}{c}\mathrm{BF} \\
\text { per } \mathrm{g}\end{array}$ & $\begin{array}{c}\text { N.p }- \text { S } \\
\left(\frac{8}{6}\right)\end{array}$ & $\underset{\left(\frac{8}{\delta}\right)}{\text { N.p-d }}$ & $\begin{array}{l}\text { Gr.i } \\
(\%)\end{array}$ & $\begin{array}{l}\text { G.b } \\
(8)\end{array}$ & $\begin{array}{l}\text { Ga.u } \\
(\%)\end{array}$ & $\begin{array}{l}\text { G.q } \\
(8)\end{array}$ & $\begin{array}{l}\text { test } \\
(\%)\end{array}$ & $\delta_{00}^{13} \mathrm{C}$ & $\%$ \\
\hline 41.10 & 3.42 & 1740.00 & 5.00 & 91.29 & 2.10 & 0.00 & 1.50 & 0.60 & 4.50 & 12.31 & 0.61 & 2.01 \\
\hline 41.20 & 4.39 & 3744.00 & 17.00 & 91.86 & 2.26 & 0.00 & 2.26 & 0.00 & 4.07 & 14.48 & 0.74 & 1.79 \\
\hline 41.40 & 5.09 & 9953.00 & 205.00 & 95.47 & 1.23 & 0.00 & 0.82 & 0.00 & 2.47 & 12.76 & 0.70 & 2.12 \\
\hline 41.60 & 3.05 & 4100.00 & 34.00 & 93.70 & 2.10 & 0.00 & 0.00 & 0.00 & 4.20 & 12.61 & 0.62 & 2.86 \\
\hline 41.79 & 2.14 & 843.00 & 16.00 & 84.68 & 1.39 & 0.00 & 0.84 & 0.56 & 12.53 & 22.56 & 0.68 & 1.91 \\
\hline 41.99 & 3.27 & 2842.00 & 17.00 & 95.41 & 1.22 & 0.00 & 0.92 & 0.61 & 1.83 & 22.94 & 0.58 & 2.75 \\
\hline 42.20 & 2.09 & 1696.00 & 26.00 & 99.39 & 0.61 & 0.00 & 0.00 & 0.00 & 0.00 & 35.60 & 0.62 & 3.79 \\
\hline 42.30 & 2.10 & 1234.00 & 8.00 & 96.57 & 2.05 & 0.00 & 0.68 & 0.00 & 0.68 & 26.03 & 0.24 & 3.52 \\
\hline 42.44 & 2.00 & 1600.00 & 9.00 & 97.19 & 1.51 & 0.00 & 0.00 & 0.22 & 1.08 & 22.03 & 0.86 & 3.82 \\
\hline 42.79 & 1.79 & 800.00 & 2.00 & 98 & 1.24 & 0.00 & 0.00 & 0.00 & 0.62 & 17.08 & 0.72 & 3.45 \\
\hline 42.89 & 4.29 & 1695.00 & 28.00 & 96.72 & 1.64 & 0.00 & 1.09 & 0.00 & 0.55 & 16.94 & 0.66 & 3.57 \\
\hline 43.10 & 2.33 & 818.00 & 6.00 & 99.27 & 0.73 & 0.00 & 0.00 & 0.00 & 0.00 & 24.82 & 0.28 & 3.78 \\
\hline 43.30 & 2.26 & 3598.00 & 17.00 & 85.65 & 4.00 & 0.00 & 3.53 & 0.47 & 6.35 & 4.00 & 0.50 & 3.57 \\
\hline 43.49 & 2.49 & 1244.00 & 15.00 & 86.34 & 1.86 & 0.00 & 4.97 & 0.00 & 6.83 & 19.88 & 0.30 & 3.72 \\
\hline 43.70 & 3.25 & 4507.00 & 40.00 & 88.00 & 1.78 & 0.89 & 4.89 & 0.89 & 3.56 & 12.00 & 0.25 & 3.46 \\
\hline 43.80 & 3.31 & 4031.00 & 19.00 & 94.76 & 1.42 & 0.00 & 1.90 & 0.00 & 1.90 & 16.59 & 0.21 & 3.73 \\
\hline 44.00 & 4.30 & 8082.00 & 111.00 & 88.53 & 3.67 & 0.00 & 1.83 & 0.00 & 5.96 & 14.22 & 0.13 & 2.98 \\
\hline 44.10 & 3.62 & 8657.00 & 93.00 & 79.57 & 3.44 & 1.51 & 3.23 & 1.51 & 10.75 & 5.81 & 0.05 & 2.98 \\
\hline 44.20 & 3.00 & 2723.00 & 31.00 & 81.82 & 5.68 & 0.76 & 5.68 & 0.00 & 6.06 & 4.55 & 0.25 & 3.32 \\
\hline 44.40 & 7.52 & 3807.00 & 22.00 & 92.35 & 3.12 & 0.00 & 0.57 & 0.00 & 3.97 & 4.53 & 0.22 & 3.01 \\
\hline 44.61 & 3.78 & 3847.00 & 22.00 & 86.44 & 4.52 & 0.00 & 5.65 & 0.00 & 3.39 & 3.95 & 0.15 & 2.84 \\
\hline 44.75 & 3.32 & 2249.00 & 17.00 & 97.74 & 1.13 & 0.00 & 0.38 & 0.00 & 0.75 & 9.43 & 0.09 & 2.74 \\
\hline 44.98 & 5.18 & 6885.00 & 44.00 & 96.84 & 1.58 & 0.00 & 0.32 & 0.00 & 1.26 & 20.25 & 0.04 & 3.03 \\
\hline 45.21 & 5.43 & 417.00 & 7.00 & 100.00 & 0.00 & 0.00 & 0.00 & 0.00 & 0.00 & 13.09 & -0.03 & 3.69 \\
\hline 45.30 & 10.00 & 200.00 & 14.00 & 100.00 & 0.00 & 0.00 & 0.00 & 0.00 & 0.00 & 60.71 & -0.12 & 3.80 \\
\hline 45.50 & 7.11 & 12178.00 & 96.00 & 95.55 & 2.62 & 0.00 & 0.00 & 0.00 & 1.83 & 15.18 & 0.40 & 4.13 \\
\hline 45.60 & 5.59 & 2444.00 & 24.00 & 96.50 & 1.17 & 0.00 & 0.00 & 0.00 & 2.33 & 32.63 & 0.35 & 4.54 \\
\hline 45.70 & 7.00 & 10129.00 & 138.00 & 95.68 & 1.82 & 0.00 & 0.00 & 0.00 & 2.50 & 16.82 & 0.34 & 4.57 \\
\hline 45.90 & 3.94 & 6522.00 & 22.00 & 95.92 & 2.72 & 0.00 & 0.00 & 0.00 & 1.36 & 18.03 & -0.12 & 3.64 \\
\hline 46.08 & 12.12 & 72.00 & 18.00 & 100.00 & 0.00 & 0.00 & 0.00 & 0.00 & 0.00 & 50.00 & 0.10 & 3.87 \\
\hline 46.30 & 6.17 & 7381.00 & 232.00 & 96.00 & 3.14 & 0.00 & 0.29 & 0.00 & 0.57 & 50.28 & 0.42 & 4.41 \\
\hline 46.90 & 5.09 & 5102.00 & 13.00 & 96.03 & 0.50 & 0.00 & 0.50 & 0.00 & 2.48 & 7.69 & -0.13 & 3.09 \\
\hline 47.10 & 2.39 & 2916.00 & 46.00 & 97.62 & 1.99 & 0.39 & 0.00 & 0.00 & 0.00 & 13.49 & -0.27 & 2.70 \\
\hline 47.30 & 10.05 & 3284.00 & 9.00 & 96.60 & 2.62 & 0.00 & 0.26 & 0.00 & 0.52 & 19.90 & 0.01 & 2.99 \\
\hline 47.50 & 7.13 & 16291.00 & 45.00 & 97.53 & 2.47 & 0.00 & 0.00 & 0.00 & 0.00 & 18.68 & 0.04 & 2.88 \\
\hline 47.70 & 3.80 & 5000.00 & 36.00 & 95.59 & 0.74 & 0.00 & 1.10 & 0.00 & 2.57 & 5.88 & 0.34 & 2.62 \\
\hline 47.89 & 5.16 & 9877.00 & 22.00 & 86.85 & 1.59 & 0.00 & 0.23 & 0.00 & 11.34 & 6.12 & -0.12 & 2.46 \\
\hline 48.02 & 1.12 & 1662.00 & 7.00 & 88.68 & 2.88 & 0.00 & 0.41 & 0.62 & 7.41 & 4.94 & -0.60 & 2.07 \\
\hline 48.24 & 3.58 & 4931.00 & 27.00 & 91.67 & 2.18 & 0.00 & 0.41 & 0.00 & 5.60 & 2.18 & -0.21 & 2.45 \\
\hline 48.40 & 4.65 & 2289.00 & 9.00 & 93.22 & 0.97 & 0.00 & 0.00 & 0.19 & 5.62 & 6.39 & -0.39 & 2.11 \\
\hline 48.56 & 5.49 & 1731.00 & 12.00 & 96.67 & 1.33 & 0.00 & 0.00 & 0.00 & 2.00 & 38.00 & -0.46 & 2.06 \\
\hline 48.80 & 0.37 & 839.00 & 3.00 & 96.67 & 1.00 & 0.00 & 0.00 & 0.00 & 2.33 & 22.67 & -0.35 & 2.64 \\
\hline 49.00 & 0.90 & 1131.00 & 66.00 & 87.63 & 2.75 & 0.00 & 0.00 & 0.69 & 8.93 & 16.84 & -0.26 & 2.58 \\
\hline 49.18 & 0.42 & 387.00 & 1.00 & 53.12 & 6.24 & 0.89 & 1.66 & 3.06 & 35.03 & 5.99 & -0.37 & 2.30 \\
\hline 49.39 & 0.93 & 948.00 & 4.00 & 99.56 & 0.44 & 0.00 & 0.00 & 0.00 & 0.00 & 51.53 & 0.30 & 3.28 \\
\hline 49.68 & 3.41 & 2203.00 & 11.00 & 99.25 & 0.75 & 0.00 & 0.00 & 0.00 & 0.00 & 23.75 & 0.10 & 2.80 \\
\hline 49.99 & 9.09 & 1970.00 & 25.00 & 100.00 & 0.00 & 0.00 & 0.00 & 0.00 & 0.00 & 26.48 & 0.13 & 3.00 \\
\hline 50.00 & 7.97 & 2240.00 & 15.00 & 96.35 & 2.33 & 0.00 & 0.17 & 0.17 & 1.00 & 12.46 & 0.28 & 3.44 \\
\hline 50.20 & 2.05 & 252.00 & 9.00 & 100.00 & 00 & 0.00 & 0.00 & 0.00 & 0.00 & 19.39 & 0.35 & 3.52 \\
\hline 50.40 & 1.34 & 4298.00 & 15.00 & 99.60 & 0.38 & 0.00 & 0.00 & 0.00 & 0.00 & 39.47 & -0.31 & 3.12 \\
\hline 50.59 & 1.40 & 2997.00 & 20.00 & 99.32 & 0.68 & 0.00 & 0.00 & 0.00 & 0.00 & 18.29 & -0.32 & 2.77 \\
\hline 50.80 & 0.44 & 911.00 & 11.00 & 99.60 & 0.40 & 0.00 & 0.00 & 0.00 & 0.00 & 24.41 & -0.18 & 2.74 \\
\hline 51.00 & 1.96 & 300.00 & 12.00 & 99.49 & 0.51 & 0.00 & 0.00 & 0.00 & 0.00 & 8.59 & 0.25 & 2.91 \\
\hline 51.21 & 7.21 & 5100.00 & 10.00 & 99.22 & 0.78 & 0.00 & 0.00 & 0.00 & 0.00 & 20.43 & -0.25 & 3.57 \\
\hline 51.39 & 2.55 & 3237.00 & 10.00 & 96.91 & 1.23 & 0.00 & 0.00 & 0.00 & 1.85 & 8.02 & -0.34 & 3.71 \\
\hline 51.50 & 10.21 & 405.00 & 3.00 & 98.34 & 0.99 & 0.00 & 0.00 & 0.00 & 0.66 & 8.31 & -0.49 & 3.41 \\
\hline 51.70 & 5.03 & 0 & 12.00 & 100.00 & 0.00 & & 0.00 & 0.00 & 0.00 & 27.22 & -0.57 & 3.59 \\
\hline 51.90 & 9.80 & 5.00 & 0.00 & 100.00 & 0 & 0.00 & 0.00 & 0.00 & 0.00 & 1.75 & -0.90 & 3.90 \\
\hline 52.10 & 5.51 & 245.00 & 12.00 & 99.33 & 0.67 & 0.00 & 0.00 & 0.00 & 0.00 & 29.97 & -0.25 & 4.34 \\
\hline 52.29 & 2.71 & 21.00 & 7.00 & 95.38 & 4.62 & 0.00 & 0.00 & 0.00 & 0.00 & 47.69 & -0.51 & 4.04 \\
\hline 52.50 & 8.01 & 1484.00 & 4.00 & 99.11 & 0.89 & 0.00 & 0.00 & 0.00 & 0.00 & 9.82 & -0.69 & 4.70 \\
\hline 52.78 & 4.41 & 37.00 & 12.00 & 100.00 & 0.00 & 0.00 & 0.00 & 0.00 & 0.00 & 40.65 & -0.29 & 4.51 \\
\hline 52.90 & 11.39 & 481.00 & 3.00 & 100.00 & 0.00 & 0.00 & 0.00 & 0.00 & 0.00 & 12.80 & -0.25 & 4.23 \\
\hline 53.04 & 9.87 & 708.00 & 15.00 & 97.91 & 2.09 & 0.00 & 0.00 & 0.00 & 0.00 & 10.45 & -0.50 & 4.21 \\
\hline 53.20 & 2.79 & 39.00 & 4.00 & 99.42 & 0.29 & 0.00 & 0.00 & 0.00 & 0.29 & 13.41 & -0.24 & 4.34 \\
\hline 53.39 & 4.60 & 435.00 & 10.00 & 100.00 & 0.00 & 0.00 & 0.00 & 0.00 & 0.00 & 13.97 & -0.69 & 3.88 \\
\hline 53.60 & 4.22 & 200.00 & 3.00 & 100.00 & 0.00 & 0.00 & 0.00 & 0.00 & 0.00 & 26.38 & -0.35 & 4.10 \\
\hline 53.80 & 3.55 & 2886.00 & 54.00 & 99.44 & 0.56 & 0.00 & 0.00 & 0.00 & 0.00 & 29.05 & -0.70 & 4.09 \\
\hline & 3.99 & 3810.00 & 21.00 & 100.00 & 0.00 & 0.00 & 0.00 & 0.00 & 0.00 & 20.59 & -0.35 & 3.74 \\
\hline 54.20 & 3.77 & 62.00 & 1.00 & & 0.9 & 0.00 & 0.00 & 0.00 & 0.00 & 7.24 & -1.00 & 3.70 \\
\hline 54.38 & 10.30 & 127.00 & 34.00 & 100.00 & 0.00 & 0.00 & 0.00 & 0.00 & 0.00 & 28.81 & -0.29 & 4.06 \\
\hline
\end{tabular}


Appendix A (continued).

\begin{tabular}{|c|c|c|c|c|c|c|c|c|c|c|c|c|}
\hline $\begin{array}{l}\text { depth } \\
\text { (mbsf) }\end{array}$ & $\begin{array}{c}>63 / \mathrm{m} \\
(8)\end{array}$ & $\begin{array}{c}\mathrm{PF} \\
\text { per } \mathrm{g}\end{array}$ & $\stackrel{\text { per } g}{g}$ & $\underset{(8)}{\text { N.p-s }}$ & $\underset{\left(\frac{8}{8}\right)}{\text { N.p-d }}$ & $\begin{array}{l}\text { Gr.i } \\
(8)\end{array}$ & $\begin{array}{l}\text { G.b } \\
(q)\end{array}$ & $\begin{array}{l}\text { Ga.u } \\
(\text { (o) }\end{array}$ & $\begin{array}{l}\text { G.q } \\
\left(\frac{8}{8}\right)\end{array}$ & $\begin{array}{l}\text { test } \\
(z)\end{array}$ & $\delta_{\circ}^{13} c$ & $\%$ \\
\hline .47 & 7.48 & 0.00 & 0.00 & 100 & . & . & 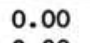 & 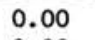 & . & 9.00 & -0.34 & 0 \\
\hline & & & & & & & & & & & & 3.94 \\
\hline 54.87 & 1.04 & 2.00 & 0.00 & 100.00 & 0.00 & 0.00 & .00 & .00 & 0.00 & 38.89 & -0.60 & 3.85 \\
\hline 55.08 & 8.12 & 856.00 & 17.00 & 100.00 & 0.00 & 0.00 & .00 & .00 & & & -0.35 & 3.64 \\
\hline 55.30 & 5.54 & 9313.00 & 96.00 & & 30 & 0.00 & & .00 & 0.00 & 14.38 & -0.90 & 3.60 \\
\hline 55.50 & 4.21 & 15888.00 & 92.00 & & 1.73 & & & & & & 0.10 & 3.12 \\
\hline 55.70 & 2.82 & 4376.00 & 15.00 & & 1.40 & & & & 0.00 & & 0.35 & 2.74 \\
\hline 55.87 & 1,75 & 6012.00 & 29.00 & 98.55 & 1.45 & & 0.00 & 0.00 & 0.00 & 11.33 & 0.26 & 2.50 \\
\hline 56.04 & 1.68 & 1678.00 & 61.00 & 97.93 & & & & 0.00 & 0.26 & 11.39 & 0.17 & 3.88 \\
\hline 56.18 & 0.77 & 1036 & 24.00 & & 1.90 & & & & & & -0.08 & 2.84 \\
\hline 56.40 & 0.56 & 354.00 & 3.00 & 64.08 & 12.62 & 6.80 & 0.97 & 6.80 & 8.74 & & 0.02 & 2.76 \\
\hline 56.60 & 0.30 & 110.00 & 2.00 & & 10.44 & 7.69 & & 7.69 & 9.89 & 3.85 & 0.05 & 2.50 \\
\hline $\begin{array}{l}56.80 \\
57.00\end{array}$ & $\begin{array}{l}0.79 \\
0.69\end{array}$ & & & & & & & & & & $\begin{array}{r}0.10 \\
-0.05\end{array}$ & $\begin{array}{l}2.66 \\
2.59\end{array}$ \\
\hline 57.20 & 0.85 & 364.00 & 2.00 & & 5.99 & 5.39 & & & 7.19 & 9.58 & -0.04 & 2.50 \\
\hline 57.40 & 1.13 & 1431.00 & 95.00 & & 8.43 & 1807 & & & 9.04 & 4.82 & -0.05 & 2.74 \\
\hline 57.50 & 1.0 & & 1 & & 9.97 & & & & 7.64 & & 0.00 & 2.44 \\
\hline 57.59 & 0.31 & & 1.00 & & 12. & & & & 12.57 & & 0.00 & 2.29 \\
\hline 57.90 & 0.99 & 508.00 & 12.00 & 74.90 & 7.33 & & 0.77 & & 9.27 & 3.86 & -0.05 & 2.75 \\
\hline 58.08 & 0.65 & 380.00 & 3.00 & & & & & & 19.47 & 6.78 & -0.47 & 2.71 \\
\hline 58.29 & 0.94 & & 7.00 & & 3.59 & & & 0.45 & & & -0.40 & 3.10 \\
\hline 58.50 & 1.79 & 3982 & 47.00 & 57. & 15.62 & 3. & & 3.91 & 16.79 & 3.12 & -0.29 & 2.81 \\
\hline 58.68 & 0.95 & & 5.00 & 66 & 12 & & & 4.24 & 24 & 4.24 & 0.00 & 2.64 \\
\hline 58.78 & 1.29 & 00 & 24 & 97 & 0. & 0. & 0. & 0.00 & 1.29 & & -0.31 & 3.14 \\
\hline 59.00 & 1.59 & 00 & 48.00 & 96. & 0 & 0.00 & & & 2.31 & 94 & -0.20 & 3.34 \\
\hline 59.19 & 10.44 & & .00 & & & & & 0 & 4.21 & & -0.72 & 3.66 \\
\hline 59.60 & 11.00 & & 00 & & 6 & 0.00 & 0 & & 0 & & -0.49 & 3.59 \\
\hline 59.85 & 59 & .00 & 00 & 98,37 & 1.63 & 0.00 & 0 & .00 & 0.00 & 19.11 & -0.34 & 3.55 \\
\hline 60.03 & 3. 38 & 00 & .00 & & 0.82 & 0,00 & & & 3.27 & 7.35 & -0.40 & 3.48 \\
\hline 60.20 & 6.40 & 00 & 00 & & & 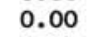 & & & 0.00 & 7 & -0.42 & 3.33 \\
\hline 61 & 2.00 & .00 & 00 & 10 & 00 & 0.00 & & & 0.00 & & -0.42 & 3.45 \\
\hline 1 & 10.74 & 0 & 00 & & & 000 & 0 & & 0.00 & & -0.52 & 3.85 \\
\hline & & 2.00 & .00 & & .00 & 0.00 & 0 & .00 & 0.00 & & & 3.92 \\
\hline 62.51 & 0.70 & 28.00 & 0.00 & & 5.88 & 0.00 & & 00 & 0.00 & & -0.95 & 3.46 \\
\hline 62.61 & 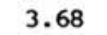 & 100 & 00 & & & 0 & 0 & & 3 & & -0.68 & 3.40 \\
\hline 62.83 & 2.00 & 98.00 & r & & 0.61 & 0.00 & 0 & & & & -0.26 & 3.25 \\
\hline 63.00 & 2.59 & 8.00 & .00 & & 1.3 & 1. & & & 14 & 2 & -0.35 & 3.49 \\
\hline & & & & & & & & & 0 & 1 & & 3.92 \\
\hline & 2.97 & .00 & & & S & 0 & & & (N) & & & 2.64 \\
\hline 63.69 & 5.61 & 11575.00 & 12 & 9 & 2.14 & 0.00 & 00 & 10 & 0.00 & 35 & -0.29 & 2.56 \\
\hline & & & & & & & 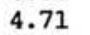 & & & 44 & -0.37 & 2.41 \\
\hline & 2 & & 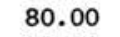 & & & & & & & & & 2.15 \\
\hline 64.14 & 2.3 & .00 & 0 & 94. & & & & & & 5.82 & & 1.64 \\
\hline & & .00 & 0 & 100 & & 0 & & & , & .37 & -0.30 & 2.68 \\
\hline 64.50 & 2 & 00 & 0 & & & 0 & 0 & & & & -0 & 2.79 \\
\hline 64.74 & 6.39 & .00 & .00 & 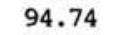 & 4.2 & 0. & & 0 & & 26.32 & 58 & 3.66 \\
\hline & & & & & & & & & & 7.00 & -0.45 & 3.23 \\
\hline & 15.0 & 00 & 53 & & & 0 & & & & & -0 & 4.27 \\
\hline 65.35 & 12 & 00 & 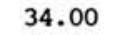 & 99.48 & 0.52 & 0.0 & & & & & 0.15 & 4.19 \\
\hline $65=2$ & & & & & & & & & & & & 3.25 \\
\hline & & & & & & & & & & & & $\begin{array}{l}3.42 \\
3.25\end{array}$ \\
\hline 66.00 & & & & & & & & & & & .06 & 3.00 \\
\hline 66.23 & 9.17 & .00 & & & & & & & & 7.89 & -0.07 & 2.99 \\
\hline & & & & & & & & & & & & 3.17 \\
\hline & & & & & & 0. & & & 2 & 7 & -0 & 3.13 \\
\hline 66.82 & & 1908.00 & & & & & & & & & & 2.72 \\
\hline & & .00 & & & & & & & & 1.23 & & 2.83 \\
\hline & & & & & & & & & & & 46 & 2.8 \\
\hline 67. & 6 & & & & & & & & & & & 2.45 \\
\hline & & & & & & & & & & & & 3.25 \\
\hline & & & & & & & & & & & & 3.14 \\
\hline & & & & & & & & & & & & 2.74 \\
\hline & & & & & & & & & & & & 2.62 \\
\hline 68. & 2 & 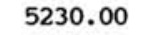 & & & & & & & & & & 2.30 \\
\hline & & & & & & & & & & & & 2.59 \\
\hline & & & & & & & & & & & & 2.5 \\
\hline & & & & 100 & & & & & & & -0.82 & 2.66 \\
\hline & & & & & & & & & & & & 2.90 \\
\hline & & & & & & & & & & & & 3.08 \\
\hline 69.41 & 12.74 & 6.00 & .00 & 9 & 0.59 & 0.00 & 0 & 0. & 7 & 14.08 & -0.49 & 3.20 \\
\hline
\end{tabular}


Appendix A (continued).

\begin{tabular}{|c|c|c|c|c|c|c|c|c|c|c|c|c|}
\hline $\begin{array}{l}\text { depth } \\
\text { (mbsf) }\end{array}$ & $\begin{array}{c}>63 \mu \mathrm{m} \\
(\%)\end{array}$ & $\begin{array}{c}\text { PF } \\
\text { per } g\end{array}$ & $\begin{array}{l}\mathrm{BF} \\
\text { per } \mathrm{g}\end{array}$ & $\begin{array}{c}\text { N.p-S } \\
\left(\frac{8}{8}\right)\end{array}$ & $\underset{\left(\frac{6}{6}\right)}{\text { N.p-d }}$ & $\begin{array}{l}\text { Gr.i } \\
(\%)\end{array}$ & $\begin{array}{l}\text { G.b } \\
(8)\end{array}$ & $\begin{array}{l}\text { Ga.u } \\
(\%)\end{array}$ & $\begin{array}{l}\text { G.q } \\
(z)\end{array}$ & $\begin{array}{l}\text { test } \\
(\%)\end{array}$ & ${ }_{\%}^{\delta^{13} \mathrm{C}}$ & $\%$ \\
\hline 2 & 568 & 0 & 00 & 4 & 4.76 & 00 & 0.00 & 0.00 & 0.00 & 4.76 & -0.44 & (נ) \\
\hline 69.75 & 5.1 & 4.00 & .00 & & & & & & & & & 3.57 \\
\hline 69.96 & 0.97 & 114.00 & 1.00 & 99.31 & 5 & & & & & & & 3.65 \\
\hline 70.19 & 1.02 & & 500 & & & & 00 & 00 & 0.00 & 2.14 & -0.30 & 3.70 \\
\hline 70. & 1.2 & 154. & 2.00 & & & & & & & 5.31 & & 3.64 \\
\hline 70.51 & 6.8 & 1695.00 & 66.00 & & 0 Q & & & & & & & 3.70 \\
\hline 70.75 & 0.89 & & 000 & & & & 0.00 & & 0.00 & 0.00 & -0.65 & 3.70 \\
\hline 70.89 & 4.2 & 2315.00 & 15.00 & & & & & & & & -0.69 & 3.70 \\
\hline 71.04 & 0.55 & 22.00 & 1.00 & & 290 & & & & & & & 3.78 \\
\hline 71. & 3.10 & & 27.00 & & & 0 & 0.00 & & 0.48 & 30.95 & -0 & 3.71 \\
\hline 71.4 & 14.8 & & & & & & & & & & -0.80 & 3.79 \\
\hline 71.68 & 6.86 & & & & & & & & & & & 3.53 \\
\hline 71.8 & 3.8 & 00 & 6.00 & 0 & & 0 & & & 0.00 & 37.04 & -0. & 3.23 \\
\hline 72.0 & & 0.00 & 0.00 & & & & & & 0.00 & & -0.56 & 3.97 \\
\hline 72. & 0.3 & 38 & & & & & & & & & & 2.71 \\
\hline 72.3 & $0 . \epsilon$ & 225 & 9.00 & & & & 0 & & 2.94 & & -0.60 & 2.90 \\
\hline 72.5 & & 106 & 28.00 & & & 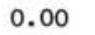 & & & 0.00 & & 0.00 & 3.41 \\
\hline 72.72 & 2.5 & & & & & & & & & & & 3.15 \\
\hline & & & & & & & & & & & & 3.18 \\
\hline 73. & 9.0 & 0.0 & 0.00 & & (0) & 00 & & & & & & 3.24 \\
\hline 73. & 3.1 & 34. & 7.00 & 100 & & & & & 0.00 & & 0.04 & 3.25 \\
\hline 73. & 1. & & 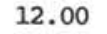 & & & & & & & & & 2.89 \\
\hline 73. & 5.2 & 30 & 1 & & & & & & & & & 2.64 \\
\hline 74.0 & 0.2 & 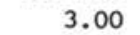 & 0 & & & 0 & & & & & -0 & 2.09 \\
\hline & 0 & & & & & & & & & & & 1.70 \\
\hline 74 & 0.8 & & 5 & & 1 & $0 .($ & & & & & & 2.14 \\
\hline 74.60 & 14.9 & & 0 & & & 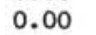 & & & & 8 & -0 & 2.37 \\
\hline 74.8 & & & & & & & & & & & & 2.92 \\
\hline 75.04 & 3.5 & 0 & 0 & & 0.0 & 0.0 & & & & & -0 & 3.29 \\
\hline 75.3 & 0.91 & 996.00 & 33.00 & & & 0 . & & & 0. & 4 & 5 & 3.76 \\
\hline & 1.68 & & & 10 & & & & & & & .30 & 3.89 \\
\hline 75 & 1.66 & 47 & 77 & & & 0 & & & $0 . c$ & & & 4.13 \\
\hline 75 & 5.1 & & .00 & & 6 & 0. & & & 0. & & .27 & 3.77 \\
\hline & 15 & & & & & & & & & & & 3.28 \\
\hline 76 & 1. & & & & & & & & & & & 3.36 \\
\hline & 5.60 & & 10 & & & & & & 0. & & & 3.50 \\
\hline 76 & 4.99 & & & & & & & & & & & 3.43 \\
\hline 76 & 15 & 0 & & & & & & & & & 6 & 3.36 \\
\hline & & 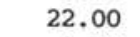 & 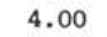 & & & & & & ) & & 1 & 3.26 \\
\hline 77 & 6 & & & & & & & & & & & 3.16 \\
\hline 77 & & & & & & & & & & & 6 & 3.14 \\
\hline & & & & & & & & & & & & 3.06 \\
\hline 77 & & & & & & & & & & & & 3.05 \\
\hline & & & & & & & & & & & 44 & 2.99 \\
\hline & & & & & & & & & & & & 3.09 \\
\hline & & 0.0 & & & & & & & & & & 3.40 \\
\hline & & & & & & & & & & & & 3.53 \\
\hline 78 & & & & & & & & & & & & 3.41 \\
\hline & & & 170 & & & & & & & & & 3.54 \\
\hline & & & & & & & & & & & & 3.65 \\
\hline 79.12 & 1.60 & 0 & & & & & & & & & & 3.54 \\
\hline 79.32 & & & & & & & & & & & & 3.49 \\
\hline & & & & 00. & & & & & & & & 3.40 \\
\hline & & & & & & & & & & & & 3.21 \\
\hline & & & & & & & & & & & & 3.24 \\
\hline & & & & & & & & & & & & \\
\hline & & & & & & & & & & & & \\
\hline & & & & & & & & & & & & 3.51 \\
\hline 80. & & & & & & & & & & & & 3.60 \\
\hline & & & & & & & & & & & & 3.69 \\
\hline & & & & & & & & & & & & 3.76 \\
\hline & & & & & & & & & & & & 3.82 \\
\hline & & & & & & & & & & & & 3.74 \\
\hline & & & & & & & & & & & & 0 \\
\hline & & & & 0 & & & & & & & & 3.87 \\
\hline & & & & & & & & & & & & \\
\hline & & & & & & & & & & 0.00 & -0.10 & 4.64 \\
\hline & & & & & & & & & & & & 4.18 \\
\hline 85.10 & 1.13 & .00 & 0.00 & 5.90 & 0.97 & 0.00 & 0.98 & 0.00 & 2.15 & 29.12 & -0.25 & 3.62 \\
\hline
\end{tabular}


APPENDIX B.

ODP Hole 647B. Foraminiferal and stable isotopic data. PF, BF (planktonic and benthic foraminifers per dry weight sediment, respectively), N.p-s, N.p-d (N. pachyderma sinistral and dextral, respectively), N.d (N. dutertrei), G.b (G. bulloides), G.q (G. quinqueloba), Gr.i (Gr. inflata), Gr.sp (Gr. tumida, Gr. scitula, Gr. hirsuta, Gr. crassaformis, Gr. menardii and Gr. truncatulinoides), Ga.u (Ga. uvula and $\mathrm{Ga}$. glutinata), test (foraminiferal test fragmentation), $\delta^{18} \mathrm{O}$ and $\delta^{13} \mathrm{C}$ (oxygen and carbon isotopic values in $N$. padchyderma sinistral).

\begin{tabular}{|c|c|c|c|c|c|c|c|c|c|c|c|c|c|c|}
\hline $\begin{array}{l}\text { depth } \\
\text { (mbsf) }\end{array}$ & $\begin{array}{c}>63 \mu \mathrm{mm} \\
(8)\end{array}$ & $\begin{array}{c}\text { PF } \\
\text { per } g\end{array}$ & $\begin{array}{l}\text { BF } \\
\text { per } g\end{array}$ & $\begin{array}{c}\text { N.p }- \text { S } \\
\left(\frac{2}{6}\right)\end{array}$ & $\underset{(8)}{\text { N.p-d }}$ & $\begin{array}{l}\text { N.d } \\
\left(\frac{6}{6}\right)\end{array}$ & $\begin{array}{l}\text { G.b } \\
(\text { (q) }\end{array}$ & $\begin{array}{l}\text { G.q } \\
\left(\frac{q}{6}\right)\end{array}$ & $\begin{array}{l}\text { Gr.i } \\
(8)\end{array}$ & $\begin{array}{l}\text { Gr.sp } \\
(\text { (६) }\end{array}$ & $\begin{array}{l}\text { Ga.u } \\
(\%)\end{array}$ & $\begin{array}{l}\text { test } \\
(8)\end{array}$ & $\begin{array}{l}\delta^{18} 0 \\
\% \circ\end{array}$ & $\begin{array}{l}\delta^{13} \mathrm{C} \\
\% \%\end{array}$ \\
\hline 0.00 & & & 102.00 & .95 & 98 & 32 & 9 & 2 & 30 & 0.33 & 4.30 & 22.85 & 2.09 & 0.28 \\
\hline 0.20 & & & & & & 40 & & & & & & & 2.67 & 0.17 \\
\hline 0.40 & 13 & 92.00 & 300 & 100.00 & 0.00 & 0.00 & & & & 0.00 & 0.00 & 0.00 & 3.20 & 0.09 \\
\hline 0.60 & 12.20 & 47.00 & 1.00 & 95.73 & 3.42 & .00 & 0.00 & 0.85 & 0.00 & 0.00 & 0.00 & 100.00 & 4.19 & 0.26 \\
\hline 0.72 & 1319 & 832.00 & 13.00 & 96.15 & 3.85 & 0.00 & 0.00 & 0.00 & 0.00 & 0.00 & 0.00 & 60.77 & 3.84 & 0.05 \\
\hline 1.10 & 12.69 & 2790.00 & 64.00 & 88. & 2.29 & 0.00 & 4.17 & & 0.00 & & 0.00 & 6.88 & 3.86 & 0.27 \\
\hline 1.29 & 14.67 & 2320.00 & 42.00 & 96.39 & 3.01 & 0.00 & 0.60 & 0.00 & 0.00 & 0.00 & 0.00 & 8.43 & 3.45 & 0.06 \\
\hline 1.48 & 14.68 & 4444.00 & 33.00 & 91.04 & 4.48 & 0.00 & 2.24 & & 0.75 & 0.00 & 0.00 & 11.19 & 3.75 & 0.30 \\
\hline 1.70 & 12.62 & 3379.00 & 39.00 & 96. & 1.71 & 0.00 & & & & & 0.00 & & 3.71 & 0.35 \\
\hline 1.90 & 12. & 12179.00 & 78.00 & 92.99 & 0.64 & 0.00 & 5.10 & 0.00 & 1.27 & 0.00 & 0.00 & 49.68 & 3.62 & 0.30 \\
\hline 2.10 & 13.10 & .00 & 48.00 & 70.00 & 16.11 & 0.56 & 11.67 & & 1.67 & 0.00 & 0.00 & 37.78 & 3.50 & 0.29 \\
\hline 2.30 & 12.61 & 00 & & & 3.03 & 0.00 & & & & & & & 3.73 & 0.29 \\
\hline 2.50 & 9 & & & 96. & 3.13 & 0.00 & & & 0.00 & & & 9.97 & 3.85 & 0.34 \\
\hline 2.80 & 9.00 & & 67.00 & 90. & 6.36 & 0.00 & 1.82 & 0.00 & 0.91 & 0.00 & 0.00 & & 3.11 & -0.07 \\
\hline 3.00 & 9.48 & 00 & 61.00 & 87.50 & 8.93 & 0.00 & 3.57 & & 0.00 & 0. & 0.00 & 21 & 3.05 & 0.06 \\
\hline 3.20 & 8.96 & 00 & 59.00 & 82.88 & & 0.00 & & & & & & 07 & 3.26 & 0.30 \\
\hline 3.40 & 7.24 & & 17. & & 2.72 & 0.00 & & & & & & & & -0.08 \\
\hline 3.60 & 8.50 & 00 & 48.00 & 77. & 9.24 & 0.00 & & & 0.00 & 0.0 & 0.84 & 85 & 3.16 & 0.12 \\
\hline 3.80 & 6.75 & & 16.00 & 81.47 & 4.67 & 0.00 & & & 0.13 & 0.00 & 1.73 & 22.13 & 3.19 & 0.23 \\
\hline 4.00 & 6.25 & 464 & 83. & & 2.40 & 0.00 & & & & & & & 3.77 & -0.07 \\
\hline 4.30 & 5.64 & & 4.00 & 99.50 & 0.50 & 0.00 & & & 0.00 & & 0.00 & 33.50 & 4.12 & 0.13 \\
\hline 4.50 & 5.65 & & 90.00 & 95.70 & & 0.00 & & & & & & & 3.89 & 0.22 \\
\hline 4.70 & 7.55 & & 63. & 73. & 10.28 & 0.00 & 9. & & & & & & 3.07 & 0.24 \\
\hline 4.90 & 11.75 & 00 & 14.00 & 95.89 & 2.74 & 0.00 & 0.00 & 0.68 & 0.00 & 0.0 & 0.68 & 55 & 2.57 & -0.01 \\
\hline 5.10 & 12 & & 3.00 & 98.20 & 1.80 & 0.00 & 0.0 & 0. & 0.00 & 0.0 & 0.0 & 7.19 & 3.20 & 0.23 \\
\hline 5.30 & 13.2 & 00 & 57. & 92. & 7.0 & 0.0 & 0 & & & & & & 2.95 & 0.11 \\
\hline 5.50 & 12 & 00 & 42.00 & 97. & 2.97 & 0.00 & 0.00 & 0. & 0 & 0. & 0. & 3 & 2.55 & -0.05 \\
\hline 5.80 & 13. & & 0 & 1 & 3.37 & 0.00 & 1.12 & & 0.00 & & 0. & & 3.94 & 0.00 \\
\hline 6.00 & 12.80 & 304 & 32. & 93. & 2.38 & 0.00 & 3 & & 8 & 0 & 0. & 6 & 2.44 & -0.01 \\
\hline 6.20 & 11.85 & 0 & 0 & 43.49 & 17.19 & 0.26 & 7 & & & & & & 2.65 & 0.16 \\
\hline 6.40 & 15.0 & 00 & 0 & 4 & & 0.43 & 9 & 2 & 4 & 0. & & & 2.79 & 0.13 \\
\hline 6.60 & 13.50 & & 0 & 52 & & 0.27 & 6 & & 3 & 0 & & & 2.15 & 0.26 \\
\hline 6.80 & 14.36 & 00 & 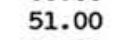 & & 8 & 0.90 & 6 & & & 0. & & & 1.52 & 0.09 \\
\hline 7.00 & 16.16 & & 0 & 51.68 & 52 & 0.88 & 10.05 & & 2 & & & & 2.91 & 0.05 \\
\hline 7.30 & & & 0 & 20. & & 0.0 & 000 & & 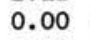 & & & 8 & 4.18 & -0.24 \\
\hline 7.51 & 8.2 & & .00 & 99.60 & 0.40 & 0.00 & 0.00 & & 0 & 0. & & 0 & 4.14 & -0.09 \\
\hline 7.73 & 9 & 00 & 00 & & 0.96 & 0.00 & 0.00 & 0. & 0.00 & 0. & 0. & .69 & 4.50 & 0.17 \\
\hline 8.10 & 7 & & ? & 0 & 7.00 & 0.00 & 0 & & & 1. & 0. & & 4.27 & 0.34 \\
\hline 8.30 & 7.0 & 00 & 00 & 1 & 12.08 & 0.00 & 1. & & & & & & 4.14 & .54 \\
\hline 8.50 & 13 & 00 & 44.00 & 8 & 5.57 & 0.00 & 6.81 & & 0.62 & 0 . & 0. & & 4.25 & 0.25 \\
\hline 8.70 & 20. & 00 & & ? & 8.6 & 1.54 & 82.46 & & & & & & 2.56 & 0.27 \\
\hline 8.90 & 20. & & & 98. & 7 & 0.00 & 0. & & & & 0.0 & & 3.11 & 0.24 \\
\hline 9.10 & 7 & & & & & 1.00 & 54 & & & & & & 3.14 & -0.26 \\
\hline 9.30 & 11. & & & & & & 57 & & & & & & & 0.28 \\
\hline 9.59 & 9.32 & 00 & 0 & 5 & 0 & 0.00 & 5. & & & 0 & & & & 0.09 \\
\hline 9.80 & 7 & & & & 45 & 0.0 & 2.42 & & 0.00 & 0. & & & 4.15 & -0.25 \\
\hline 10.00 & 2 & & & & & & .26 & & & & & & & 0.37 \\
\hline 10.20 & 10.55 & .00 & & & & & $L$ & & & & & & 2.34 & .18 \\
\hline & & & & & & & & 14. & & & & & 2.44 & -0.05 \\
\hline 10.70 & 7 & & & & & & 6 & & & & & & & -0.04 \\
\hline 10.90 & & & 14.00 & 4.6 & 5.17 & & & & & & & & 3.84 & -0.32 \\
\hline & 2 & & & & & & 2.00 & & & & & & 2.53 & -0.05 \\
\hline 11.30 & & & & & 11 & & & & & & & & & \\
\hline 11.50 & 20 & or & 9 & 7 & & & & & & & & & 4.06 & -0.58 \\
\hline & & & & & & & & & & & & & & 0.09 \\
\hline 11.90 & 10.97 & & & & & & & & & & & & & 0.04 \\
\hline 12.09 & & .00 & & 9.8 & 0.97 & & & & & & & & 3.58 & 0.18 \\
\hline & & & & & & & & & & & & 14.03 & 4.04 & -0.14 \\
\hline 12.60 & 8.82 & & & & 18 & & & & & & & & 5.73 & -0.20 \\
\hline & 10. & & & . & 3.2 & & & & & & & & 4.08 & 0.16 \\
\hline & & & & & & & 4.23 & & & 0.00 & & 8.46 & 3.96 & 0.00 \\
\hline 13.20 & 9.32 & & & & & & & & & & & 23.10 & 3.80 & 0.08 \\
\hline & & & & 20.90 & & & & & & & & & 4.15 & 12 \\
\hline & & & & & & & 4 & & 1. & & & 14.50 & 3.96 & -0.04 \\
\hline 13.80 & 7.74 & & & & & & & & & & & & 4.22 & 0.00 \\
\hline 11 & 10.00 & 228.00 & 9.00 & 45.03 & 9.42 & 0.00 & 34.55 & 5.24 & 2.09 & 1.57 & 2.09 & 18.32 & 2.79 & -0.06 \\
\hline
\end{tabular}


Appendix B (continued).

\begin{tabular}{|c|c|c|c|c|c|c|c|c|c|c|c|c|c|c|}
\hline $\begin{array}{l}\text { depth } \\
\text { (mbsf) }\end{array}$ & $\begin{array}{c}>63 \mu \mathrm{mm} \\
(8)\end{array}$ & $\begin{array}{c}\text { PF } \\
\text { per } g\end{array}$ & $\begin{array}{c}\mathrm{BF} \\
\text { per } g\end{array}$ & $\underset{\left(\frac{8}{8}\right)}{\text { N.p-s }}$ & $\underset{(8)}{\text { N.p-d }}$ & $\begin{array}{l}\text { N.d } \\
(q)\end{array}$ & $\begin{array}{l}\text { G.b } \\
(8)\end{array}$ & $\begin{array}{l}\text { G.q } \\
(\%)\end{array}$ & $\begin{array}{l}\text { Gr.i } \\
(8)\end{array}$ & $\begin{array}{l}\text { Gr.sp } \\
\text { (8) }\end{array}$ & $\begin{array}{l}\text { Ga.u } \\
(8)\end{array}$ & $\begin{array}{r}\text { test } \\
(\%)\end{array}$ & $\begin{array}{l}\delta^{18} 0 \\
\% \circ\end{array}$ & $\begin{array}{l}\delta^{13} \mathrm{C} \\
\% \% 0\end{array}$ \\
\hline 14.30 & 12.48 & .00 & 14.00 & 61.41 & 8.68 & 0.96 & 20.58 & 3.22 & 0.64 & 0.96 & 3.54 & 22.51 & 2.74 & -0.04 \\
\hline 14.50 & 10.96 & & & & & & & 6.85 & & & & 25.40 & 2.94 & 0.04 \\
\hline 14.69 & 11.10 & 8575.00 & 53.00 & 54.04 & 9.11 & 0.83 & 12.84 & 16.36 & 0.41 & 1.24 & & & & -0.28 \\
\hline 14.90 & 10.45 & 9978.00 & 82.00 & 55.74 & 6.56 & 0.00 & 18.85 & 10.66 & 0.82 & 0.82 & & & 3.30 & -0.03 \\
\hline 15.10 & 11.72 & 8765.00 & 48.00 & 46.17 & 9.84 & 1.09 & 30.60 & 4.10 & 2.73 & 0.55 & 4.64 & 20.49 & 3.10 & 0.14 \\
\hline 15.30 & 12.25 & 17432.00 & 91.00 & 14.40 & 23.56 & 2.62 & 23.30 & 15.97 & 12.30 & 1.05 & 6.81 & 17.80 & 2.20 & -0.13 \\
\hline 15.60 & 14.00 & 38569.00 & 319.00 & 12.40 & 28.93 & 4.13 & 22.31 & 13.22 & 9.92 & 3.31 & & & & 0.29 \\
\hline 15.80 & 9.48 & 16090.00 & 53.00 & 13.91 & 32.78 & 0.99 & 21.19 & 11.92 & 11.26 & 0.33 & & 14.24 & 2.76 & 0.53 \\
\hline 16.00 & 18.85 & 14860.00 & 51.00 & 20.07 & 29.93 & 2.04 & 20.07 & 6.80 & 14.63 & 1.02 & 4.42 & 6.80 & 3.00 & 0.05 \\
\hline 16.20 & 14.25 & 9333.00 & 77.00 & 22.10 & 23.48 & 2.76 & 11.60 & 19.06 & 14.92 & 0.55 & 3.59 & 11.05 & 3.00 & 0.35 \\
\hline 16.40 & 14.05 & 211 & 239.00 & & 22.18 & & & 05 & 90 & & & 20.30 & 2.51 & 0.14 \\
\hline 16.60 & 17.3 & $263 \epsilon$ & 86. & 30. & 20. & 1.30 & 26 & 16 & & & 2.61 & 21.82 & 3.05 & 0.19 \\
\hline 16.80 & 5.66 & 140 & 58.00 & 73 & 8.50 & 0.90 & & & 1.00 & 0. & & & 4.10 & 0.11 \\
\hline 17.10 & 7.63 & 1085.00 & 6.00 & 97.88 & 1.59 & 0.00 & 0.00 & 0.00 & 0.00 & 0.00 & 0.53 & 20.63 & 3.85 & -0.04 \\
\hline 17.30 & 5.50 & 1482.00 & 16.00 & 97.62 & 2.16 & 0.00 & 0.00 & 0.22 & 0.00 & 0.00 & 0.00 & 11.23 & 4.15 & 0.32 \\
\hline 17.50 & 5.50 & 166 & 26 & 95 & 3.08 & 0.00 & 0. & & 0.77 & 0 & & & 3.73 & 0.00 \\
\hline 17.79 & 8.45 & & 11 & 85 & 5.81 & 0.00 & 0.78 & & & & & & 3.84 & -0.07 \\
\hline 18.40 & 11.50 & $30 c$ & 18.00 & 43.50 & 16.92 & 1.21 & 28.40 & 3.93 & 4.23 & 0.30 & 1.21 & & 3.33 & 0.18 \\
\hline 18.60 & 11.35 & 834 & 43.00 & 59.59 & 14.83 & 1.28 & 14. & 1.28 & 7.16 & 0.52 & 0.51 & 11.25 & 3.82 & 0.64 \\
\hline 18.80 & 17.20 & 777 & 25.00 & 12.62 & 21.68 & 0.97 & 51.78 & 4.21 & 3.56 & 0.32 & 3.88 & 21.04 & 3.01 & 0.40 \\
\hline 19.00 & 16.55 & 523 & 17.00 & 54.26 & 11.04 & 0.00 & 12 & 16.72 & 1.58 & 1.58 & 2.52 & 71 & 3.62 & 0.47 \\
\hline 19.29 & 11.05 & 264 & 18.00 & 67.22 & 10.37 & 0.00 & 11.37 & 7.36 & & & & & 3.80 & 0.48 \\
\hline 19.50 & 8.74 & .00 & 22.00 & 74.23 & 9.28 & 0.00 & 5.15 & 7.22 & 2.58 & 0.52 & 1. & 77 & 3.35 & 0.55 \\
\hline 19.70 & 13.35 & 666 & 189.00 & 42 & 31. & 2.84 & 7.39 & 4. & 7.39 & 0.57 & & 48.30 & 2.12 & 0.45 \\
\hline 19.90 & 9.80 & .00 & 80.00 & 20.17 & 39.50 & 2.76 & 4.97 & 15.47 & 8.84 & & & & 1.50 & 0.02 \\
\hline 20.09 & 10.18 & 204 & 450.00 & 22.47 & 28.63 & 0.44 & 6.17 & 24.67 & 11.01 & 0.00 & 7 & 56 & 2.31 & 0.56 \\
\hline 20.30 & 11.55 & 00 & 37.00 & 1 & 30 & 5.88 & 6.95 & 0.53 & 11 & 1.07 & 3. & 6.95 & 2.32 & -0.64 \\
\hline 20.50 & 15.84 & .00 & 67.00 & 23.77 & 23.77 & 0.82 & 2.46 & 23.77 & 57 & 0.82 & & & 2.11 & -0.22 \\
\hline 20.80 & 20.10 & & 8.00 & 14.52 & 36.69 & 1.21 & 3.63 & 5.24 & 42 & 0.81 & 10.08 & 18.95 & 1.63 & 0.30 \\
\hline 21.00 & 0.33 & 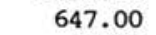 & 00 & 10.26 & 33.65 & 0.00 & 28.85 & 13.14 & 7. & 1.60 & 4 & 4.49 & 2.64 & 0.14 \\
\hline 21.20 & 4.54 & 77.00 & 9.00 & 97. & 2.82 & 0.00 & & & 0.00 & 0.00 & 0.00 & 23.47 & 4.55 & 0.11 \\
\hline 21.41 & 3.99 & 00 & 8.00 & 94.17 & 4.17 & 0.00 & 0.00 & 0.42 & 1.25 & 0.00 & 0.00 & 19.17 & 3.82 & -0.17 \\
\hline 21.60 & 9.54 & .00 & 7.00 & 84.62 & 14.69 & 0.00 & 0.70 & 0.00 & 0.00 & 0.00 & 0.00 & 18.88 & 3.93 & 0.32 \\
\hline 21.80 & 8.19 & 00 & 2.00 & 96.60 & 2.55 & 0.00 & 0.28 & 0.28 & 0.28 & 0.00 & 0.00 & 9.63 & 3.77 & 0.15 \\
\hline 22.00 & 11.88 & 13641.00 & 138.00 & 55.07 & 21.28 & 1.69 & 5.41 & 6.08 & 4.39 & 0.00 & 6.08 & 14.86 & 2.00 & 0.00 \\
\hline 22.30 & 20.10 & 432000 & חת & 84.97 & 5.12 & 0.77 & 3.58 & 3.32 & 1.53 & 0.00 & 1.53 & 10.23 & 2.56 & 0.70 \\
\hline 22.50 & 11.05 & 00 & 46 & 11 & 38 & 0.77 & 3.61 & 2.58 & 0.00 & 0.26 & 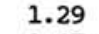 & 8.25 & 2.22 & 0.40 \\
\hline 22.70 & 18.65 & 58563.00 & 173.00 & 39.35 & 31.66 & 1.78 & 11.83 & 2.07 & 11.24 & 0.00 & 2.07 & 51.18 & 2.49 & 0.75 \\
\hline 22.90 & 20.13 & $1430^{\circ}$ & 175 & 00 & 2157 & 2.45 & 12 & 0.98 & 14.22 & 2.94 & 0 & 35.29 & 1.42 & 0.13 \\
\hline 23.10 & 19.0 & 00 & 0 & 16.43 & 8 & 2.10 & 3 & 8.74 & 8.04 & 1.40 & 4 & 8.04 & 1.52 & -0.13 \\
\hline 23.30 & 11.01 & 15629.00 & 00 & 34.00 & 08 & 2.48 & 85 & 4.96 & 8.44 & 0.75 & 5.71 & 14.39 & 2.05 & -0.16 \\
\hline .50 & 10.50 & 12376.00 & 14 & 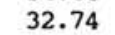 & 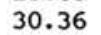 & 298 & 1518 & 3.27 & 136 & 0.60 & 3 & $3 c$ & 1.99 & -0.10 \\
\hline 23.79 & 1.03 & 00 & 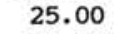 & 9 & 6 & 3.98 & 11 & 1.59 & 24.70 & 2.00 & 3. & 21.51 & 1.00 & 0.31 \\
\hline 24.00 & 20.00 & 709.00 & .00 & 8.70 & 28.70 & 3.48 & 39 & 6.09 & 9.57 & 0.87 & 5.22 & 8.70 & 2.00 & 0.35 \\
\hline 24.21 & 13.55 & 142 & & 30 & & 1.18 & & 13.51 & 4.50 & 0.24 & 3 & 2.84 & 2.01 & -0.81 \\
\hline 24.39 & 9.10 & $6]$ & 0 & 91.84 & 10 & 0.00 & 0.68 & 2.0 & 0.34 & 0. & 0.00 & 18.03 & 1.64 & -1.05 \\
\hline 24.60 & 15.40 & .00 & 84.00 & .79 & 4.22 & 0.0 & 0.84 & 18.14 & 0.00 & 0. & 0 & 97 & 3.50 & -0.36 \\
\hline 24.80 & 18.8 & .00 & 27 & 10 & 10.58 & 0. & 1.76 & 2 & 2.27 & 0. & 2 & 0 & 3.95 & 0.06 \\
\hline 25.00 & 14.51 & .00 & & .6 & 26 & 0.53 & 18.95 & 4.21 & 2.63 & 0. & 5.26 & 4.21 & 3.65 & -0.54 \\
\hline $31+2$ & די & 2 & & & & & & 14.7 & & & ח & 8.05 & 3.60 & 0.19 \\
\hline 25.50 & 2 & & 3 & 9 & 4.07 & 0.0 & 0.41 & 3. & 0.41 & 0. & 0. & 5.28 & 3.29 & -0.12 \\
\hline 25.70 & 13.30 & .00 & 24.00 & 71.80 & 4.59 & 0.00 & 1.97 & 18.69 & 1.97 & 0.00 & 0.98 & 5.90 & 3.14 & 0.09 \\
\hline 25.90 & & & & & 8.73 & 095 & & 20.2 & 5.07 & 0. & 4.23 & 10.70 & 2.55 & 0.04 \\
\hline 26.10 & .56 & & & & 7.97 & 0 . & 0.79 & 0.79 & 0.79 & & 0. & 20.16 & 2.59 & 0.12 \\
\hline 26.30 & .84 & .00 & .00 & .99 & 6.82 & 0.89 & 5.64 & 37.98 & 1.19 & 0.59 & 0 & 10.68 & 2.25 & -0.01 \\
\hline 26.50 & & & & & .50 & & 4.19 & & & 0.28 & & 4.47 & 1.89 & -0.10 \\
\hline 26.80 & 14.02 & .00 & & & 9.27 & 0. & 3.51 & & 1. & 0. & 4. & 3.19 & 1.45 & -0.20 \\
\hline 27.00 & 14.74 & 3480.00 & .00 & .17 & 9.23 & 0.00 & 5.95 & 18.45 & 7. & 0.00 & 4.17 & 15.48 & 1.99 & -0.20 \\
\hline & & 195 & 121.00 & & & & & & & & & 22.36 & 2.79 & 0.32 \\
\hline 27.59 & $2 C$ & & & & & & & & & & & 8.77 & 3.04 & 0.00 \\
\hline & & & & & & & & & & & & & & -0.05 \\
\hline & & & & & & & & 18.40 & & & & & 3.72 & -0.54 \\
\hline & & & 27 & & 0 & & & & & & & & 3.40 & \\
\hline & & 16000 & & 077 & & & & 015 & 0.00 & 0. & 0. & & 3.62 & -0.59 \\
\hline 28.60 & 8.2 & .00 & 7.00 & 10 & 0.00 & 0.00 & & 0.0 & 0.00 & 0.00 & 0.00 & 22.83 & 3.51 & -0.11 \\
\hline & & 4252.00 & & & & & & & & 0.00 & & & 3.97 & -0.35 \\
\hline & 16.5 & 640.00 & 1 & 247 & & 0. & 0. & 0.00 & 1. & 0. & 0.00 & 32.89 & 3.54 & -0.31 \\
\hline 29.30 & 6.64 & 4.00 & 4.0 & 91.53 & 6.78 & 0. & & 0.00 & 0.00 & 0.00 & 0. & 33.90 & 3.60 & -0.34 \\
\hline & & 13.00 & & & & & 0. & 0. & & & & & 3.07 & -0.38 \\
\hline & & & & & & & & 20.93 & & & & & 2.00 & -0.30 \\
\hline 29.90 & 13.25 & 17919.00 & 60.00 & 76.51 & 3.02 & 1.01 & 2.68 & 7.72 & 5.70 & 0.00 & 3.02 & 11.41 & 2.79 & 0.14 \\
\hline
\end{tabular}


Appendix B (continued).

\begin{tabular}{|c|c|c|c|c|c|c|c|c|c|c|c|c|c|c|}
\hline $\begin{array}{l}\text { depth } \\
\text { (mbsf) }\end{array}$ & $\begin{array}{c}>63 \mu \mathrm{m} \\
(8)\end{array}$ & $\begin{array}{c}\text { PF } \\
\text { per } g\end{array}$ & $\begin{array}{l}\text { BF } \\
\text { per } g\end{array}$ & $\underset{(\%)}{\text { N.p-s }}$ & $\underset{(8)}{\mathrm{N} \cdot \mathrm{p}-\mathrm{d}}$ & $\begin{array}{l}\text { N.d } \\
(\%)\end{array}$ & $\begin{array}{l}\text { G.b } \\
\left(\frac{8}{8}\right)\end{array}$ & $\begin{array}{l}\text { G.q } \\
\left(\frac{q}{6}\right)\end{array}$ & $\begin{array}{l}\text { Gr.i } \\
(8)\end{array}$ & $\begin{array}{l}\text { Gr.sp } \\
(8)\end{array}$ & $\begin{array}{l}\text { Ga.u } \\
(\text { (f) }\end{array}$ & $\begin{array}{l}\text { test } \\
(\%)\end{array}$ & $\begin{array}{l}\delta^{18} 0 \\
\% 0\end{array}$ & $\begin{array}{l}\delta^{13} \mathrm{C} \\
\% \% 0\end{array}$ \\
\hline 30.10 & 9.50 & 11307.00 & 67.00 & 92.04 & 1.18 & 0.00 & 年 & 2.65 & 2.36 & 0.29 & 0.88 & 5.60 & 1.83 & -0.05 \\
\hline 30.40 & 8.00 & 6180.00 & 42.00 & 20.68 & 46.44 & 2.37 & & 0.00 & 23.73 & 1.02 & 3.39 & & 2.21 & -0.20 \\
\hline 30.60 & 20.00 & 194.00 & 63.00 & 25.22 & 22.17 & 0.87 & 3.91 & 3.91 & 9.13 & & & & 1.45 & -0.30 \\
\hline 30.81 & 20.05 & 60.00 & 0.00 & 37.93 & 16.09 & 0.57 & 4.60 & 16.67 & 13.22 & 0.58 & 9.20 & 3.45 & 1.96 & -0.43 \\
\hline 31.00 & 9.12 & 6.00 & 0.00 & 76.67 & 7.78 & 0.00 & & 3.33 & 5.56 & 0.00 & 2.22 & 17.78 & 2.26 & -0.06 \\
\hline 31.20 & 6.84 & 3095.00 & 37.00 & & & 0.00 & & & & 0.00 & 0.00 & & 3.33 & 0.27 \\
\hline 31.40 & 10.55 & 381.00 & 16.00 & 98. & 0.94 & 0.00 & 0.00 & 0.00 & 0.47 & 0.00 & 0.00 & 26.42 & 2.98 & -0.04 \\
\hline 31.60 & 13.83 & 3035.00 & 16.00 & 85.86 & 3.14 & 1.05 & 5.24 & 0.52 & 0.52 & 0.00 & 3.66 & 19.90 & 2.99 & -0.22 \\
\hline 31.92 & 20.00 & 379.00 & 3. & & & 0.00 & & & 0.73 & 0.00 & 0.36 & 8.36 & & -0.19 \\
\hline 32.10 & 8.97 & 14133.00 & 243.00 & & 9.56 & 0.52 & 5.68 & 0. & 9.04 & 0.00 & & 10.08 & 2.62 & -0.10 \\
\hline 32.30 & 10.24 & 12734.00 & 33.00 & 50.91 & 15.93 & 0.00 & 7.05 & 13.84 & 6.53 & 1.31 & 3.66 & 14.10 & 2.55 & -0.58 \\
\hline 32.50 & 2.25 & 1772.00 & 4.00 & 41.67 & 17.82 & 0.23 & 5.32 & 17.82 & 4.40 & $1.39 \quad 1$ & 11.34 & & 1.92 & -1.12 \\
\hline 32.70 & 8.80 & 7489.00 & 18.00 & & 7.45 & 0.00 & 3.61 & & & 0.24 & 4.57 & 9.62 & 2.38 & -0.72 \\
\hline 32.90 & 5.00 & 2.00 & 0.00 & 90.00 & 3.33 & 0.00 & 0.00 & 3.33 & & 0.00 & & 23.33 & 3.00 & -0.43 \\
\hline 33.11 & 8.75 & 637.00 & 17.00 & 97.37 & 2.63 & 0.00 & 0.00 & 0.00 & 0.00 & 0.00 & & & 3.60 & -0.16 \\
\hline 33.40 & 11.58 & 1785.00 & 24 & & 2. & 0.00 & & & & 0 & & & 2.53 & -0.22 \\
\hline 33.59 & 9.8 & 57.00 & 3. & & 12. & 0.00 & & & & & & 22.32 & 3.18 & -0.26 \\
\hline 33.80 & 10.57 & 32632.00 & 261.00 & 636 & 10. & 0.00 & 12.40 & 6. & 4.00 & & & & 2.32 & -0.41 \\
\hline 33.99 & 13.20 & 5922.00 & 50.00 & 90.65 & 4.25 & 0.00 & 1.13 & 1.70 & 1.13 & 0.00 & 1.13 & 15.58 & 1.77 & -0.31 \\
\hline 34.20 & 18. & & & & 7. & 0.00 & & & & & 1.70 & 13.90 & 2.90 & -0.06 \\
\hline 34.40 & 17.26 & 15853.00 & 38 & 76 & 6.94 & 0.00 & 6. & 4. & 5.02 & & & & 2.10 & -0.17 \\
\hline 34.60 & 9.75 & 4724.00 & 16.00 & 42.22 & 23.08 & 0.00 & 13.33 & 3.76 & 10.77 & 1.02 & 5.81 & 11.45 & 1.31 & -0.58 \\
\hline 34.89 & 20.00 & 58.00 & 1.00 & 70.10 & 10.30 & 0.00 & 2.30 & 5.70 & 6.90 & 0.00 & 3.40 & 4.60 & 2.79 & -0.08 \\
\hline 35.10 & 3.24 & 0 & 0 & 69 & 12. & 0.00 & 10. & 4. & & 0.00 & 0 & 8.00 & 2.78 & 0.03 \\
\hline 35.30 & 5 & 66.00 & 4.00 & 94.50 & 2.50 & 0.00 & 1.80 & 0.60 & 0.60 & & & & 4.26 & -0.02 \\
\hline 35.49 & 8.11 & 4053.00 & 26.00 & 97.15 & 2.85 & 0.00 & 0.00 & 0.00 & 0.00 & 0. & 0 & & 3.64 & -0.12 \\
\hline 35.70 & 14.82 & 11145.00 & 174.00 & 96.88 & 2.34 & 0.00 & 0. & 0.00 & 0.78 & 0.00 & 0 & 20. & 3.71 & 0.23 \\
\hline 35.91 & 10.44 & po & 2 & 91 & 2.78 & 0.00 & 0.93 & 2.78 & & & & & 3.32 & 0.09 \\
\hline 36.10 & 20.00 & .00 & 0 & 94. & 1.32 & 0.00 & 0.88 & 1.32 & 1.32 & 0.00 & 0 & 5 & 3.08 & -0.11 \\
\hline 36.40 & 15.55 & 10442.00 & 21.00 & 1.77 & 3.23 & 0.00 & 4.84 & 12.50 & 4.23 & 0.40 & 3.02 & 7.06 & 2.63 & -0.41 \\
\hline 36.60 & 20.00 & .00 & 70.00 & 70. & 8.29 & 0.00 & 4.42 & 2.0 & & & 0. & 4.42 & 2.72 & -0.40 \\
\hline 38.60 & 9.60 & 00 & 18 & 6 & 5.19 & 0.00 & 0.49 & 1 & 9 & 0. & 9 & 4 & 3.15 & -0.06 \\
\hline 38.80 & 5.31 & .00 & 6.00 & 72.14 & 11.40 & 0.00 & 2. & 4.74 & 5.29 & 0.28 & & & 2.79 & -0.29 \\
\hline 39.00 & 6.11 & .00 & 60.00 & 72.14 & 11.40 & 0.00 & 2. & 4.74 & 5.29 & 0.28 & 3.06 & 10 & 2.79 & -0.29 \\
\hline 39.20 & 6.12 & (000 & 55.00 & 79,18 & 10.53 & 0.23 & 2.29 & 275 & 2.52 & 0.5 & 1.60 & 15.10 & 2.79 & -0.36 \\
\hline 39.40 & 7.50 & .00 & 17.00 & 2.22 & 12.78 & 0.00 & 0.83 & 7.50 & 3.89 & 0. & 1.94 & & 2.80 & -0.45 \\
\hline 39.60 & 8.77 & 40479.00 & 152.00 & 74.13 & 8.39 & 2.45 & 4.55 & 4.90 & 2.45 & 1.05 & 2.10 & 15.38 & 2.77 & -0.10 \\
\hline 39.80 & 11.59 & 1228 & 62 & 6835 & 13.67 & 0.25 & 3.80 & 3.29 & 6.33 & 1.01 & 3.04 & 14.94 & 2.64 & -0.55 \\
\hline 40.11 & 16.01 & .00 & 44.00 & 3 & 7.94 & 0.00 & 1.07 & 1.7 & 3.86 & 0.64 & 1.93 & 5.58 & 2.72 & -0.81 \\
\hline 40.30 & 7.50 & 24.00 & .00 & 65.22 & 14.29 & 1.24 & 6.21 & 4.9 & 3.11 & 3.73 & 1.24 & 8.70 & 2.95 & -0.71 \\
\hline 40.50 & 7.76 & 00 & 0 & 8.67 & 16.00 & 0.00 & 10.67 & 7 & 6.67 & 1.33 & 4.00 & 12.00 & 3.01 & -0.54 \\
\hline 40.70 & 10.05 & 10.00 & 00 & 78 & 11.11 & 0.00 & 3.70 & 5. & 1.48 & 0.00 & 0.74 & 2.22 & 3.09 & -0.41 \\
\hline 40.91 & 6.19 & 269.00 & 58.00 & 98.47 & 1.53 & 0.00 & 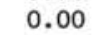 & 0.00 & 0.00 & 0.00 & 0.00 & 73.28 & 3.14 & -0.26 \\
\hline 41.10 & 19.95 & 37.00 & 177.00 & 30 & 4.10 & 0.00 & 0.00 & 0 & 1.71 & 0.0 & 0.00 & 26.96 & 2.85 & -0.35 \\
\hline 41.30 & 8 & 0 & 76 & 4.32 & 4. & 0.00 & 0. & 0 & 1. & 0. & 0. & 36.68 & 1.60 & -0.61 \\
\hline 41.60 & 6.05 & 52.00 & 4.00 & .43 & 3.57 & 0.00 & $0 .($ & 0.00 & 0.00 & 0.00 & 0.00 & 39.29 & 2.38 & -0.29 \\
\hline 41.80 & 12.49 & 27904.00 & 128.00 & 56 & 3.67 & 0.00 & 15.60 & 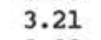 & 3.67 & 1.38 & 0.92 & 3.30 & 2.87 & -0.02 \\
\hline 42.00 & $9.2>>$ & & 1 & & 3 & 0.00 & 0.00 & 0.0 & 3. & 0. & 0.00 & 8 & 1.96 & -0.14 \\
\hline 42.20 & 15.84 & .00 & 273.00 & 4.22 & 2.89 & 0.00 & 1.7 & 0.58 & 0.00 & 0.00 & 0. & 16.18 & & 0.05 \\
\hline 42.40 & 15.75 & .00 & 100 & $60=$ & 2.44 & 0.00 & 0.3 & 0.30 & 0.00 & 0.00 & 0 . & 7.62 & 2.65 & 0.30 \\
\hline 42.60 & 11.25 & .00 & 1 & 4.03 & 10.07 & 0.0 & 0.6 & 2.1 & 1.53 & 0.22 & 1.31 & 33.48 & 2.54 & -0.17 \\
\hline 42.80 & 11.35 & 26093.00 & 123.00 & 96.45 & 1.42 & 0.00 & 1.42 & 0.00 & 0.47 & 0.00 & 0.24 & 15.13 & 3.54 & 0.76 \\
\hline 43.10 & 11.13 & & 00 & 4.58 & 11.02 & 0.00 & & 33 & 0.85 & 1.75 & 0.85 & 7.63 & 3. & 0.64 \\
\hline $43.3 c$ & 20.05 & & 2 & & & 0.0 & & 0 . & 0 . & 0.00 & 0.55 & 10.50 & 3.52 & 0.55 \\
\hline 43 & 1 & & & & & & & & & & & & 2.42 & 0.50 \\
\hline 43 & 1 & & 3 & 3.41 & 16.9 & $A$ & 5.0 & 6 & & 0. & 3. & 18.37 & 2.78 & 0.05 \\
\hline 43.90 & 13.50 & .00 & 8.00 & .38 & 12.02 & 0.00 & 10.38 & 15.30 & 2.19 & 0.55 & 2.19 & 8.20 & 2.78 & 0.03 \\
\hline 44.10 & 20.10 & & & & & & & & & & & 12.00 & 2.82 & 0.04 \\
\hline 44 & & & & & 17. & & & & 2.57 & 0 & 2. & 9.17 & 2.27 & 0.07 \\
\hline 44.59 & 15.36 & 295 & 59.0 & .43 & 3.00 & 0.00 & 1.80 & 3.19 & 2.99 & 0.00 & 0.60 & 13.37 & 1.55 & -0.05 \\
\hline 44.75 & & & & & & & 4.15 & & 6.64 & 0.50 & & 10.80 & 1.48 & -0.02 \\
\hline & 19]$. & & & & & 0.40 & 60 & & 32 & 0.00 & & & 2.34 & 0.32 \\
\hline 45.20 & 9.00 & 5559.00 & 54.00 & 75.78 & 4.49 & 0.00 & 10.74 & 3.37 & 2.34 & 0.78 & 2.34 & 20.12 & 1.30 & 0.25 \\
\hline & & & & 7.69 & 13.74 & & 12.09 & & & & & 9.89 & 2.27 & 0.35 \\
\hline & 10.2 & & & & & & & & & & 0.47 & 12.62 & 2.84 & 0.00 \\
\hline 47.60 & 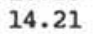 & 8 & 18 & 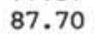 & 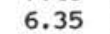 & 0. & 2 & & 0.82 & 0.00 & & 6.76 & 2.64 & 0.04 \\
\hline 47.8 & 15.56 & & & & & & & & & 0.29 & & 19.53 & 1.64 & 0.04 \\
\hline 48.00 & 20.00 & 140756.00 & 352.00 & (5) & 4. & & & 1.3 & 0.75 & 0.50 & 1.00 & 9.50 & 1.08 & -0.14 \\
\hline & 8.24 & E0ว רח & & 6.83 & & & & $1 . \varepsilon$ & 0.94 & 0.31 & & 13.17 & 1.58 & -0.04 \\
\hline & & & & & & & & & & & & & 1.48 & -0.07 \\
\hline 48.70 & 2.25 & 4297.00 & 16.00 & 89.69 & 1.91 & 0.00 & 3.82 & 1.93 & 1.15 & 0.38 & 1.15 & 15.65 & 1.37 & -0.17 \\
\hline
\end{tabular}


Appendix B (continued).

\begin{tabular}{|c|c|c|c|c|c|c|c|c|c|c|c|c|c|c|}
\hline $\begin{array}{l}\text { depth } \\
\text { (mbsf) }\end{array}$ & $\begin{array}{c}>63 \mu \mathrm{m} \\
(8)\end{array}$ & $\begin{array}{c}\mathrm{PF} \\
\text { per } \mathrm{g}\end{array}$ & $\begin{array}{l}\text { BF } \\
\text { per } g\end{array}$ & $\underset{\left(\frac{8}{8}\right)}{\text { N.p-s }}$ & $\underset{(8)}{\text { N.p-d }}$ & $\begin{array}{l}\text { N.d } \\
(f)\end{array}$ & $\begin{array}{l}\text { G.b } \\
(8)\end{array}$ & $\begin{array}{l}\text { G.q } \\
(\%)\end{array}$ & $\begin{array}{l}\text { Gr.i } \\
\text { (\%) }\end{array}$ & $\begin{array}{l}\text { Gr.sp } \\
\text { (§) }\end{array}$ & $\begin{array}{l}\text { Ga.u } \\
(\delta)\end{array}$ & $\begin{array}{c}\text { test } \\
(\%)\end{array}$ & $\begin{array}{l}\delta^{18} 0 \\
\%\end{array}$ & $\begin{array}{l}\delta^{13} \mathrm{C} \\
\% \% 0\end{array}$ \\
\hline 90 & & 11.00 & 4.00 & & & & & 3 & 01 & 0 & & 12.30 & 1.50 & 0.44 \\
\hline & & & & & & & & & & & & & & \\
\hline 49.30 & 2.49 & 00.00 & & & & & & & & & & & & 0.31 \\
\hline 49.50 & 1.52 & 96.00 & 4.00 & & 185 & & & 185 & 0.74 & & & & & -0.24 \\
\hline 49.80 & 15.20 & 147 & 41. & & 10. & & & & & & & & & -0.16 \\
\hline 50.00 & 13.30 & .00 & 179.00 & & & & & & & & & & 1.90 & -0.10 \\
\hline 50.2 & 17.4 & & & & & & & & & & & & 2.17 & -0.03 \\
\hline 50.4 & 20.0 & 16 & & & & & & & & & & & & 0.09 \\
\hline 50.60 & 11.31 & & & & & & & 15.07 & & & & & 1.69 & -0.78 \\
\hline & & & & & & & & & & & & & & \\
\hline & & 1 & & & & & & & & & & & & -0.75 \\
\hline & 14. & 25.00 & $23+2>$ & & & & & & & & & & & -0.31 \\
\hline 5 & 17. & 00 & & & & & & & & & & & 3.36 & 0.49 \\
\hline 51 70 & 14. & 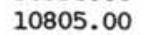 & & & & & & & & & & & & .30 \\
\hline 5 & 12. & 0 & & & & & & & & & & 8.60 & 3.10 & 0.51 \\
\hline 52 & 12. & 00 & & & .66 & & & & & & & 4.04 & 1.87 & -0.28 \\
\hline 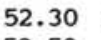 & 18.0 & & & & & & & & & & & & 1.29 & 0.10 \\
\hline & & & & & & & & & 1.21 & & & & 1. & -0.18 \\
\hline 5 & 13. & & 125 & & & & & 0.56 & 17.88 & & & & 1.62 & -0.07 \\
\hline 00 & 13.5 & 00 & & 0 & & & & 234 & & & & & 1.98 & 0.00 \\
\hline 5 & 20 & & & & & & & & & & & & & 0.08 \\
\hline 53.40 & & .00 & & & & & & & & & & & & -0.09 \\
\hline & 6.48 & & & & & & & & & & & & 3.60 & 0.50 \\
\hline & & & & & & & & 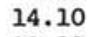 & & & & & 3. & 0.06 \\
\hline 54.00 & 10.5 & 92 & & & & & & & & & & & & -0.27 \\
\hline & & & & & & & & & & & & & & \\
\hline & & & & & & & & & & & & & & \\
\hline & & & & & & & & & & & & & & \\
\hline & & & & & & & & 促 & & & & & & 0.00 \\
\hline 5 & & & & & & & & & & & & 0 & & 0.49 \\
\hline & & & & & & & & & & & & & & -0.17 \\
\hline 55 & & & & & & & & & & & & & & 0.10 \\
\hline 55.80 & 10.5 & (1) & & 22 & 4 & 0. & & 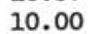 & 18 & 1. & 3. & 1. & 2. & 0.14 \\
\hline 56.00 & 9.55 & 427.00 & 20.00 & 8.78 & 55.59 & 0.00 & 6.91 & 10.90 & 15.96 & 0.27 & 1.60 & 39.89 & 0.00 & 0.00 \\
\hline
\end{tabular}

